Serie B, Nr. 7

Geological Survey of Denmark, Series B, No. 7

\title{
Lithostratigraphy and sedimentary evolution of the Triassic, Jurassic and Lower Cretaceous of Bornholm, Denmark
}

\section{BY}

Peter Gravesen, Flemming Rolle \& Finn Surlyk

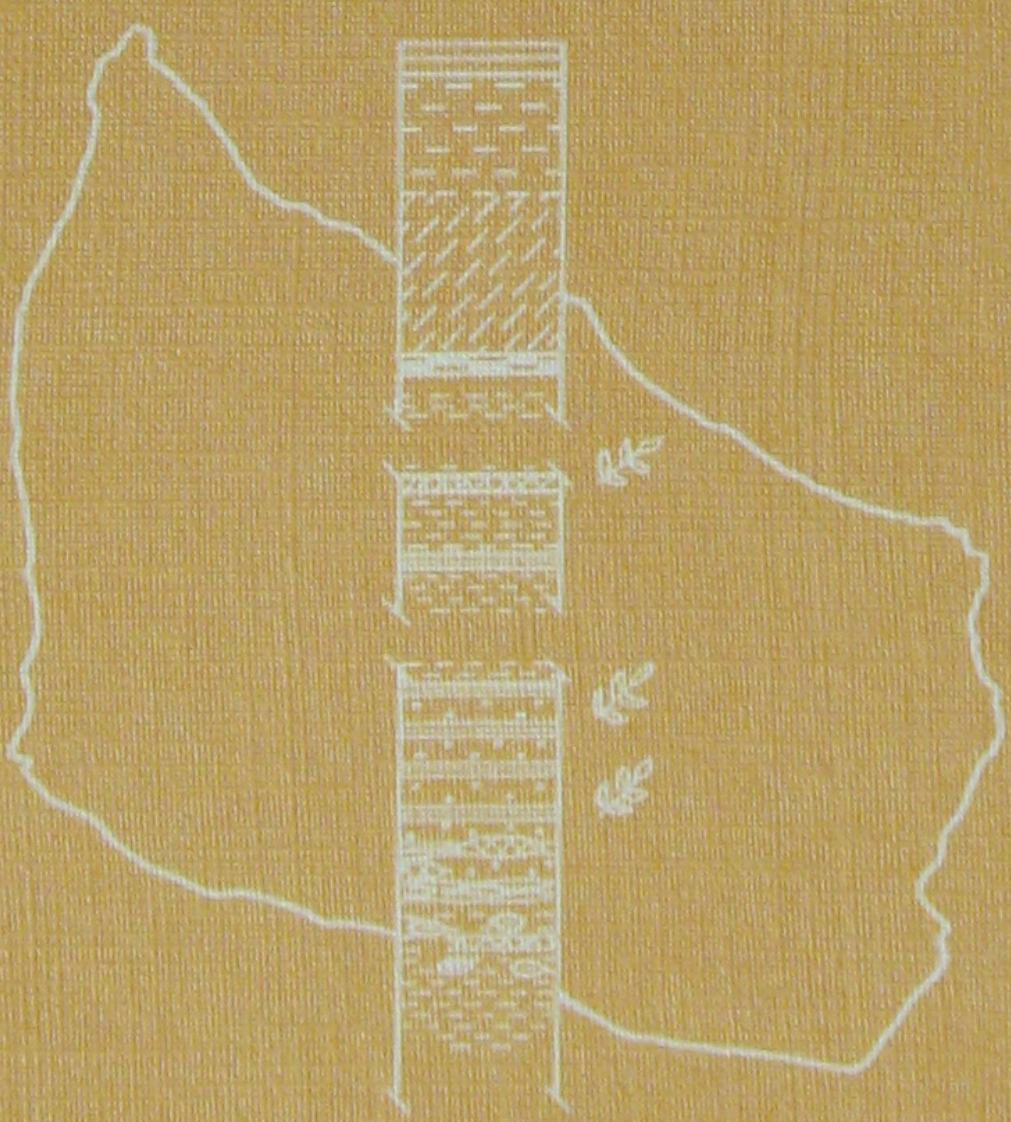


Danmarks Geologiske Undersøgelse. Serie B, Nr. 7

Geological Survey of Denmark, Series B, No. 7

\section{Lithostratigraphy and sedimentary evolution of the Triassic, Jurassic and}

\section{Lower Cretaceous of Bornholm, Denmark}

By

Peter Gravesen, Flemming Rolle \& Finn Surlyk

I kommission hos C. A. Reitzels Forlag. København 1982 
DGU Serie B, nr. 7

er sat med Foto Times

og trykt i offset i 1000 eksemplarer

hos AiO Tryk as, Odense

Bogen er trykt på Thai-Cote, $115 \mathrm{~g}$

fra a/s De forenede Papirfabrikker.

ISBN 87-421-0731-8

Date of publication 1982-04-23

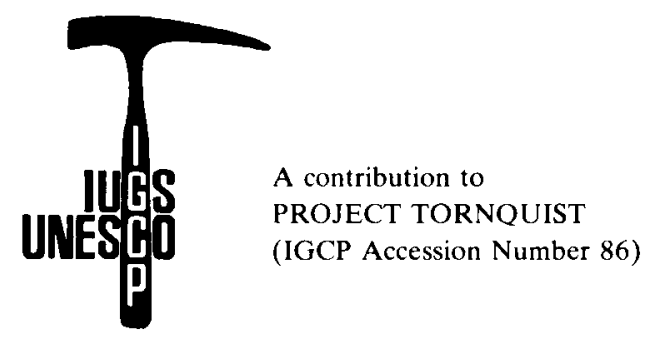

Adresses of the authors:

Peter Gravesen, The Geological Survey of Denmark, Thoravej 31, 2400 København NV, Denmark, Flemming Rolle and Finn Surlyk, The Geological Survey of Greenland, Øster Voldgade 10, 1350 København K, Denmark. 


\section{Contents}

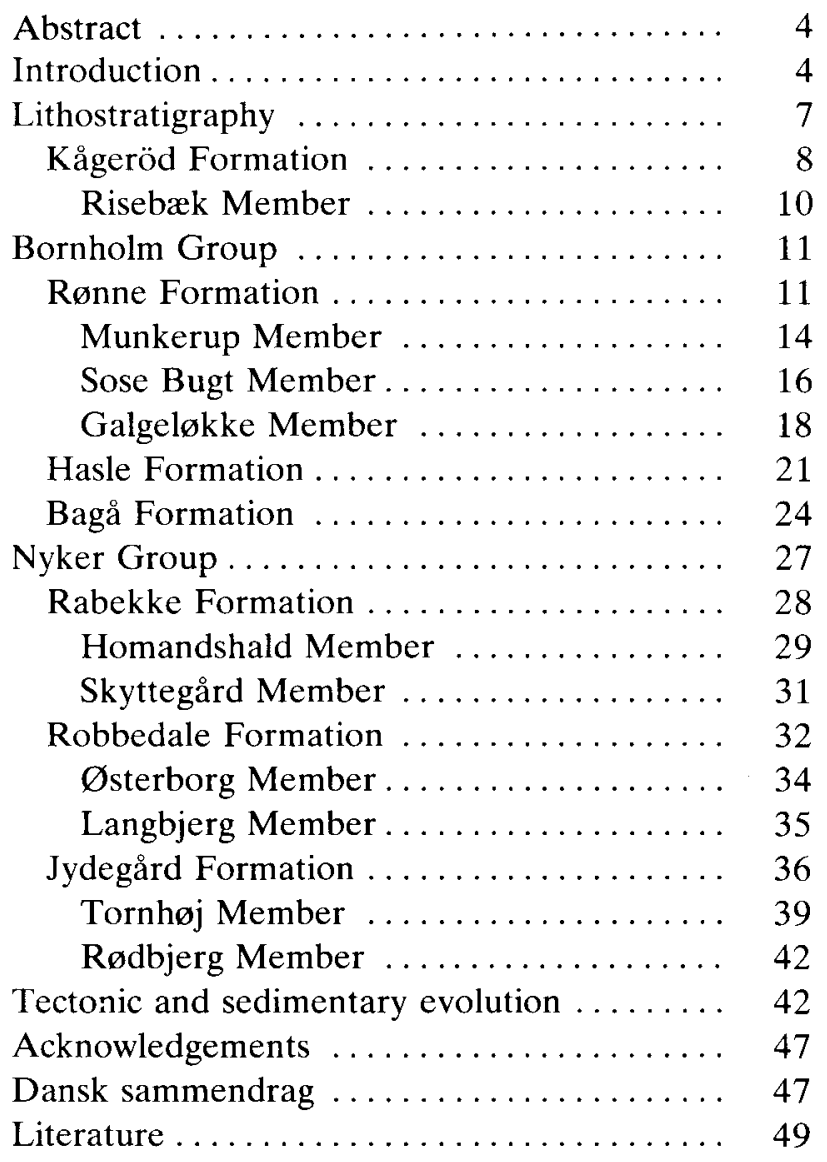




\section{Abstract}

A new lithostratigraphic subdivision of the Triassic to Lower Cretaceous sequence of Bornholm is presented including 2 new groups, 3 new formations and 10 new members. The Late Ladinian - Carnian variegated clay, sand and conglomerates of arid flood-plain origin with thin marine intercalations are tentatively referred to the Kågeröd Formation. The Jurassic sediments are placed in the Bornholm Group (new) comprising a lower Hettangian - Sinemurian Rønne Formation (new) which contains a succession of lacustrine clay, fluviatile sand and coal, and tidal flat and marsh heteroliths and sand. The overlying Lower Pliensbachian Hasle Formation (new) includes shallow marine fossiliferous sandstone, while the Bajocian - Bathonian Bagå Formation (new) is characterized by fluviatile fining-upwards sand-clay-coal sequences and resedimented conglomerates. This is followed by the Lower Cretaceous Nyker Group (new), comprising a basal Rabekke Formation (Lower Berriasian, possibly extending down into the Tithonian and up into the Upper Berriasian) which contains fluviatile coarse, sometimes ferruginous sand and sandy clay, and swamp and lagoonal dark grey clay. This is overlain by the Robbedale Formation (Upper? Berriasian) which comprises tidal flat, beach and lagoonal fine-grained sand and clay and rather coarse-grained barrier beach and shelf sand. Then follows the Jydegård Formation (uppermost Berriasian - Valanginian) comprising back-barrier and washover fan sand, and lagoonal clay, clay-ironstone and silt with thin sands.

The Triassic - Lower Cretaceous sequence thus reflects deposition in a variety of coastal environments, and while eustatic sea-level changes seem to have controlled the main facies evolution, the local depositional environments and breaks in sedimentation seem to reflect the interplay between eustacy and synsedimentary tectonic phases.

\section{Introduction}

The island of Bornholm constitutes a fault block mosaic in the southern end of the Fenno-Scandian Border Zone (Figs. 1, 2). Exposures of the Mesozoic sedimentary rocks are restricted to a few low coastal cliffs and some inland quarries. The bulk of the sequence is developed in paralic facies types which change rapidly vertically and laterally, and there is a general absence of marine fossils. Stratigraphical subdivision and correlation has thus been considerably hampered and existing nomenclature is mainly informal and descriptive. Much of the knowledge of the stratigraphy of the Triassic, Jurassic and Lower Cretaceous sequence is due to the work of Gry (1956, 1960, 1968, 1969), while the Lower Cretaceous ostracods have been studied by Christensen (1963, 1964, 1966, 1974). Other references to older work on individual units, localities or faunas are mentioned under the lithostratigraphic descriptions.

The Jurassic-Cretaceous boundary beds have been referred to in the literature as Purbeck-Wealden (Malling, 1920; Christensen, 1963, 1964; Gry, 1956, 1969). These terms originate from England and have been used in a lithostratigraphic and chronostratigraphic sense, and as general facies terms describing continental and restricted marine sediments of mainly Early Cretaceous age in most of NW Europe (Allen, 1955, 1967, 1975; Christensen, 1968, 1974; Hughes, 1958, 1975; Kemper, 1973; Dabrowska, 1976; Dörhöfer, 1976; Gravesen, 1977a). Today Purbeck and Wealden are used in a purely lithostratigraphic sense for units in southern England.

Little attention has been paid to the study of sedimentary facies and environments of the Mesozoic section of Bornholm except for the study by Sellwood $(1972,1975)$ of the Sinemurian tidal flat sequence at Galgeløkke, and of the Berriasian Robbedale Formation by Gry (1968) and Jux \& Strauch (1968). The clay mineralogy of the Jurassic and Lower Cretaceous sediments has been investigated by GraffPetersen (1961) and Graff-Petersen \& Bondam (1963). Recently sedimentological studies have been carried out on the Lower Jurassic by Rolle (1977, 1978), the Rabekke, Robbedale and Jydegard Formations by Gravesen $(1977 \mathrm{a}, \mathrm{b})$ and the Jydegård Formation by Noe-Nygaard \& Surlyk (in prep.). Reconnaissance study on the Middle Jurassic has been made by Rolle (see Rolle, Koch, Frandsen \& Surlyk, 1979). The present paper reports the stratigraphic results of these studies and is concluded with a syn- 


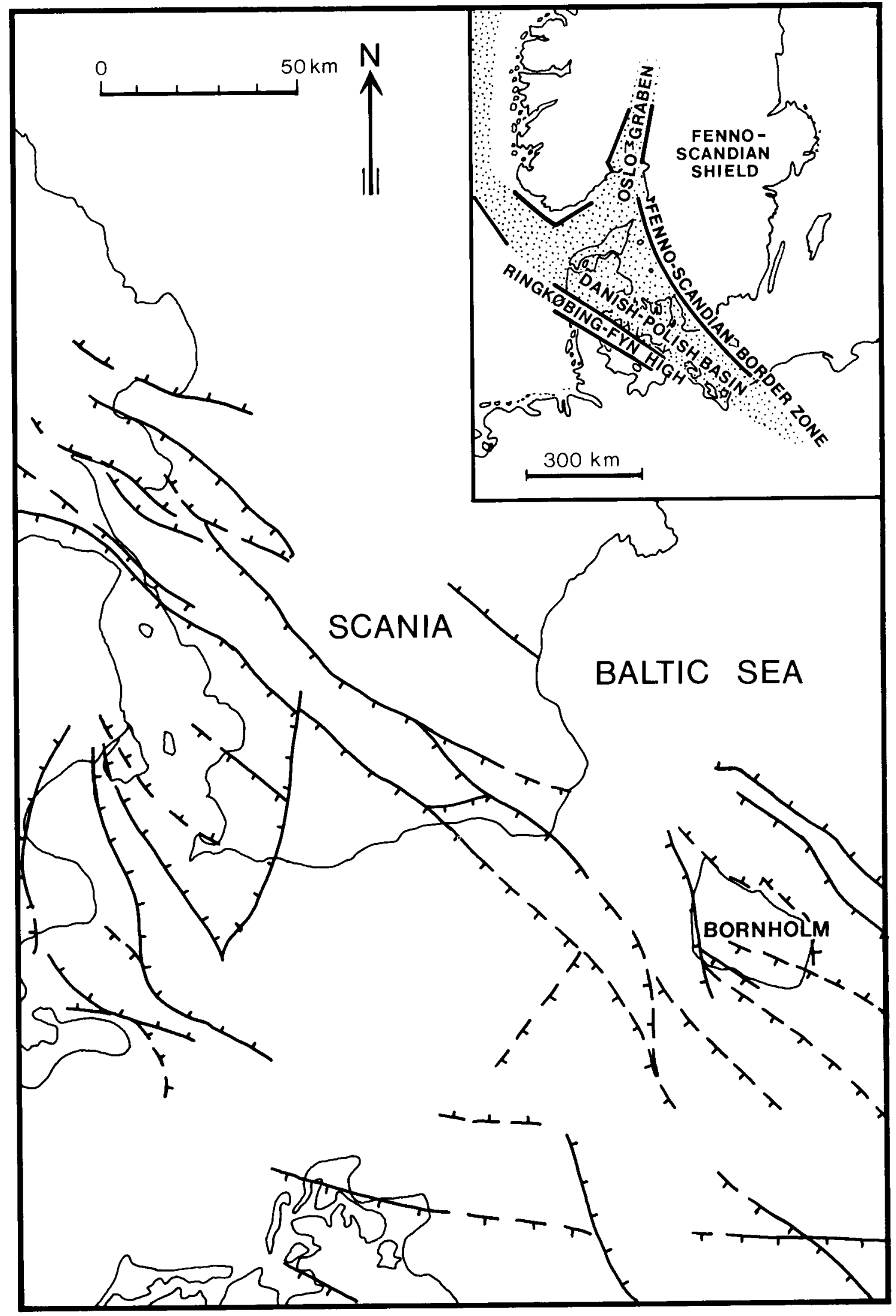

Fig. 1. Generalized map showing the position of Bornholm within the Fenno-Scandian Border Zone. Modified from compilation by Koch (1979). Sources: Nilson, 1959; Sorgenfrei, 1966; Dadlez, 1974; Andersen et al. 1975; Baartman \& Christensen, 1975; Baartman, 1976; Bjelm et al., 1977. 


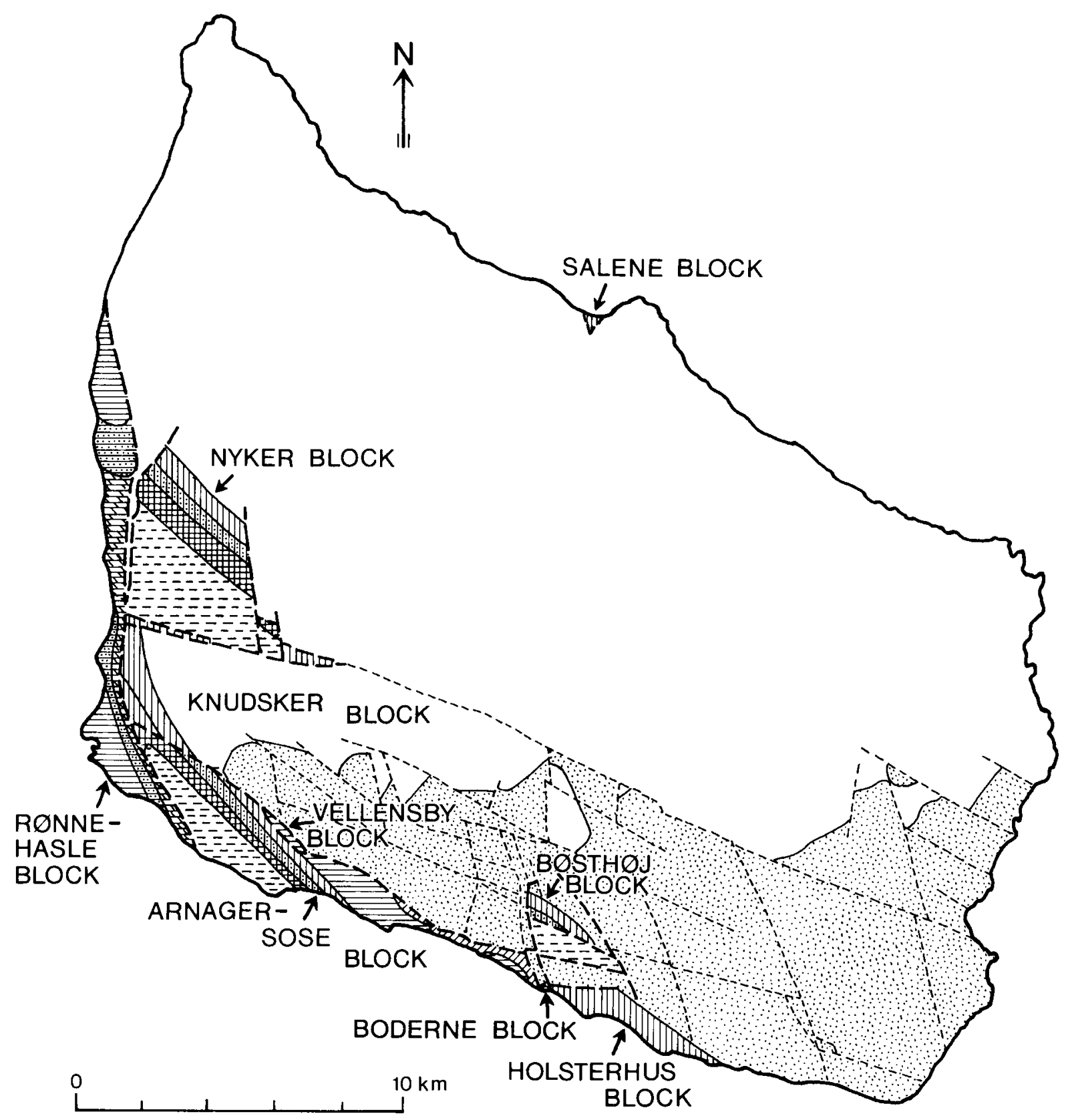

\section{LEGEND}

Upper Cretaceous

Lower Cretaceous Jydegård Formation

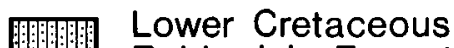
Robbedale Formation

IIIIII Lower Cretaceous Rabbekke Formation

Middle Jurassic
Bagá Formation

Lower Jurassic Hasle Formation

Lower Jurassic

Rønne Formation
Upper Triassic Kågeröd Formation

17 Lower Palaeozoic

$\square$ Precambrian basement

Main faults delineating Mesozoic blocks

Faults within Palaeozoic and Precambrian terrain

Formation boundaries

Fig. 2. Geological map of Bornholm. Modified from Gry (1960, 1969). 


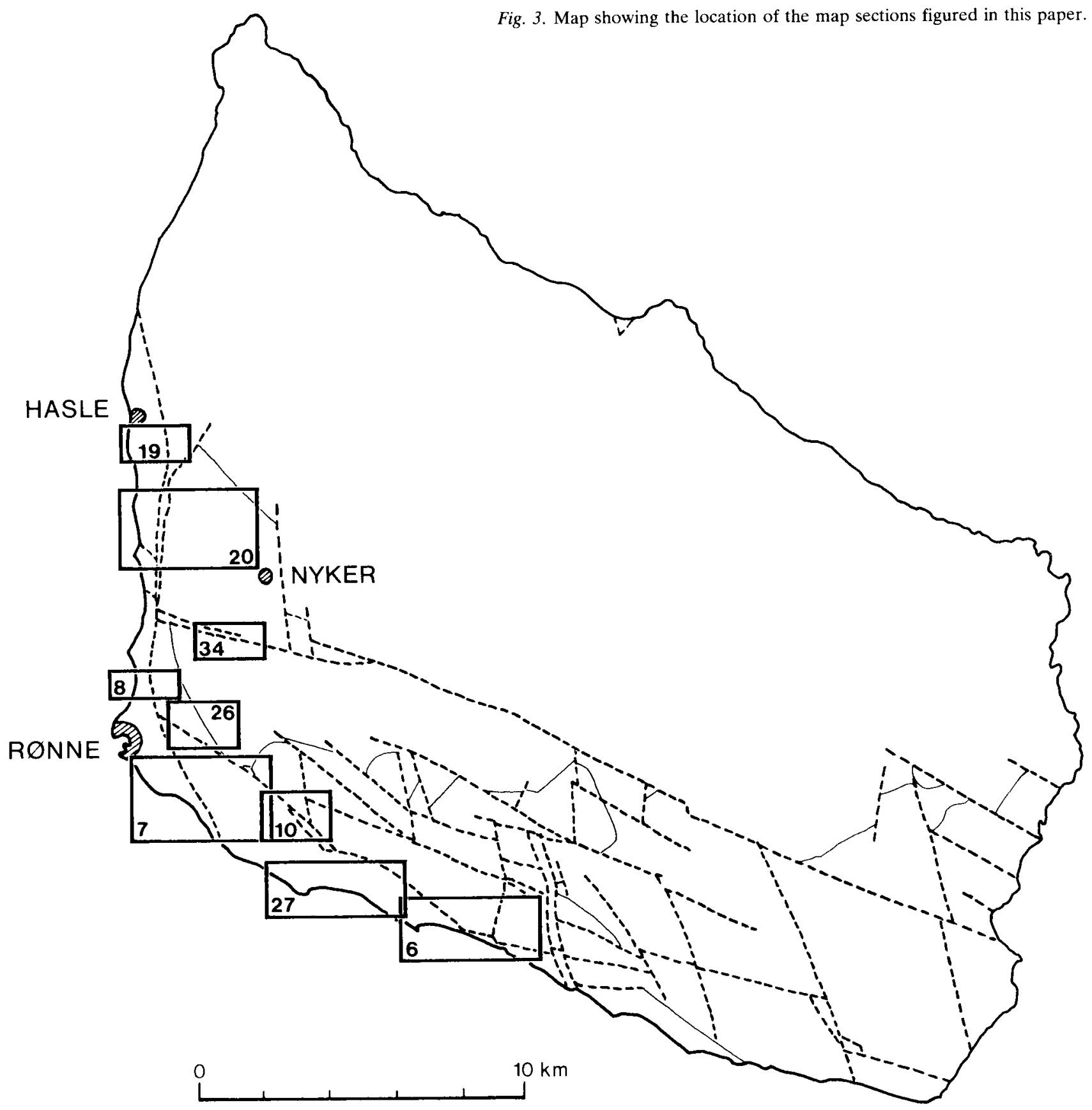

thesis of the tectonic and sedimentary evolution of Bornholm during Late Triassic to Early Cretaceous times.

\section{Lithostratigraphy}

The lithostratigraphic subdivisions of the Triassic - Lower Cretaceous of Bornholm are described below in ascending order (Figs. 4, 5). A conservative approach has been used and older informal names are used whenever possible. Extreme splitting into numerous units of low rank has been avoided although the rapid facies changes in the dominantly paralic sequences could make it possible in many local areas. Such units have, however, very limited correlation potential as the same facies types occur repeatedly and because of the pronounced lateral facies changes. The general lack of age-diagnostic fossils enhances the risk of correlating reminiscent lithologies of even quite different ages. We thus strongly recommend the practice that characteristic lithologic units recognized in restricted areas in the future are given the rank of formal beds rather than members. 


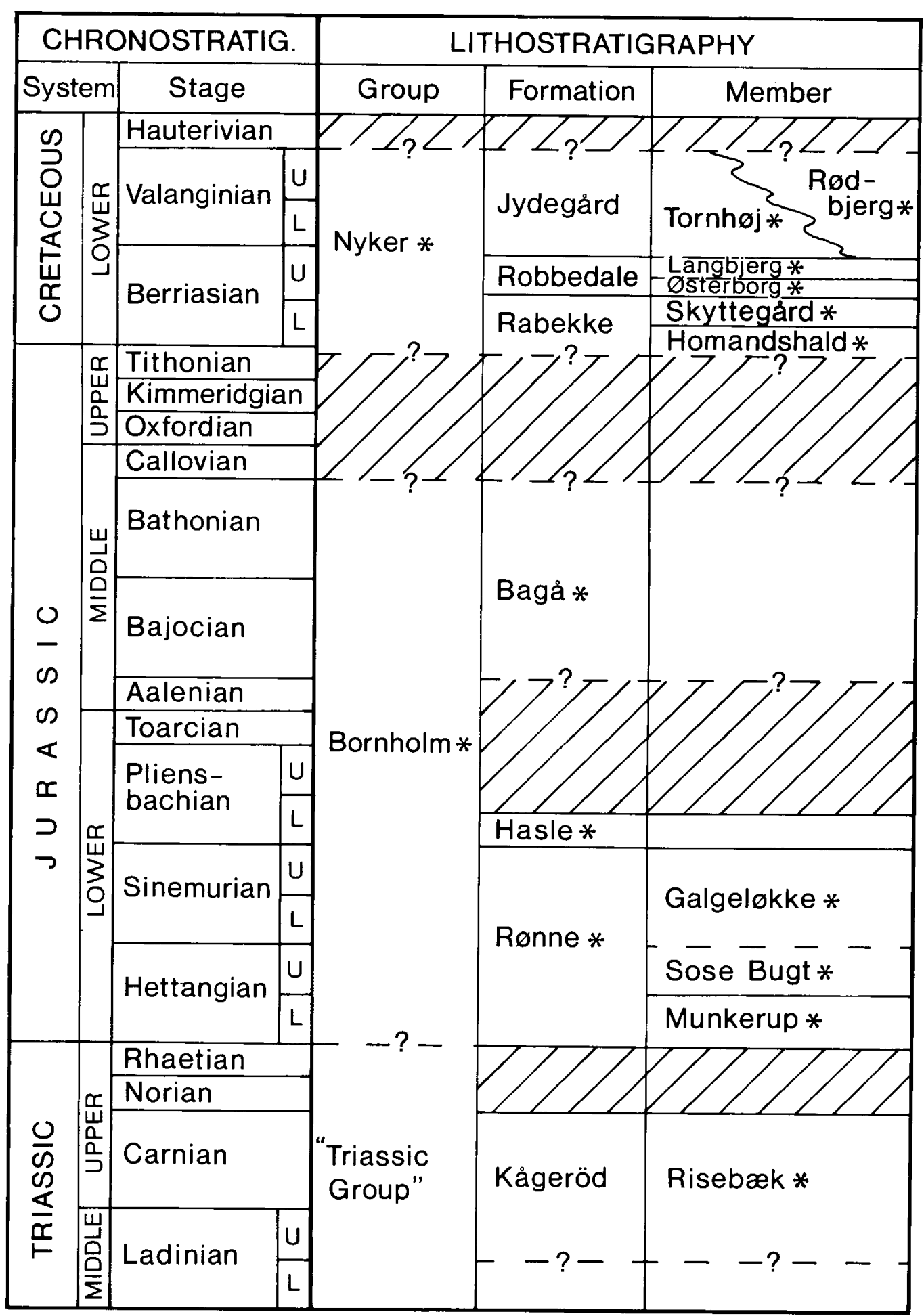

Fig. 4. Stratigraphical scheme of the Triassic Lower Cretaceous of Bornholm. * describes new units defined in the present paper. "Triassic Group" refers to a unit described by Deegan \& Scull (1977),

\section{Kågeröd Formation}

\section{Troedsson $(1934,1942)$}

The Kågeröd Formation is widely distributed in the western part of the Fenno-Scandian Border Zone in Scania (Troedsson, 1934, 1942; Köster, 1956; Allen, 1965). It has to some extent been neglected in papers describing the Triassic of the Danish underground.
Bertelsen (1980, p. 33) suggests that it represents a marginal, sandy equivalent of the Oddesund Formation, and includes it in the upper part of the Skagerrak Formation (op. cit. p. 39, 42). This practice is not followed here and is not recommended. The Kågeröd Formation is relatively well known from outcrops and boreholes and has clear priority. Furthermore, the Skagerrak Formation is very loosely defined and 


\begin{tabular}{|c|c|c|c|c|c|c|c|c|c|c|c|c|c|}
\hline \multirow{3}{*}{ 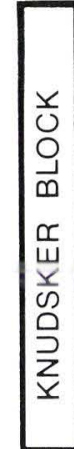 } & & & \begin{tabular}{l|l|} 
\\
1 \\
10 \\
12 \\
10 \\
10 \\
$\frac{0}{0}$ \\
10 \\
10 \\
10 \\
0
\end{tabular} & 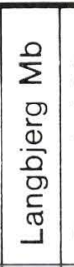 & 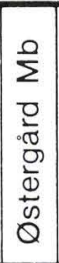 & 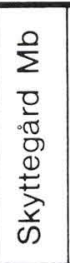 & 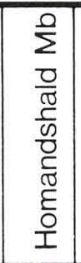 & & & & & & 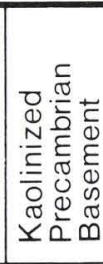 \\
\hline & $\begin{array}{r}(u) \text { ssau } \\
-y 0 ! 41 \\
\end{array}$ & & $\begin{array}{l}\text { I. } \\
\text { IF } \\
F\end{array}$ & 우 & $\wedge$ & 8 & $\begin{array}{ccc}1 & 0 \\
\forall \\
& 0 \\
\Lambda\end{array}$ & & & & & & \\
\hline & $\begin{array}{r}16601 \\
-04 ! ! 7\end{array}$ & & 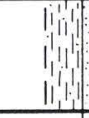 & 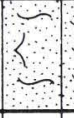 & 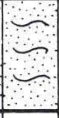 & 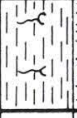 & 1 & & & & & & 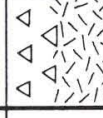 \\
\hline \multirow{3}{*}{ 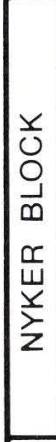 } & & 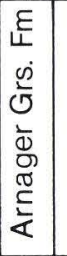 & $\begin{array}{l}\frac{0}{\Sigma} \\
0 \\
\frac{0}{0} \\
\frac{0}{0} \\
\overline{0} \\
\widetilde{0}\end{array}$ & 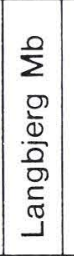 & 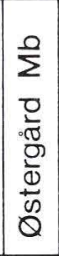 & 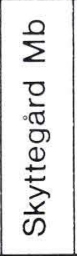 & 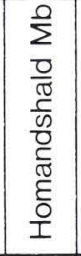 & & & & & & 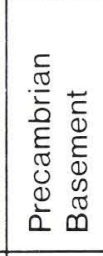 \\
\hline & $\begin{array}{c}\text { (u) ssau } \\
- \text {-y!! } 1 \\
\end{array}$ & & 우을 & 요 & $1+\infty$ & $\begin{array}{l}9 \\
9\end{array}$ & ป & & & & & & \\
\hline & $\begin{array}{r}\kappa 601 \\
-04+! 7 \\
\end{array}$ & & $\begin{array}{l}0 \\
\end{array}$ & 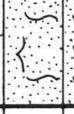 & 4 & 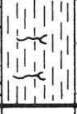 & $\begin{array}{l}1 \\
0 \\
\end{array}$ & & & & & & 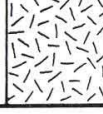 \\
\hline \multirow{3}{*}{ 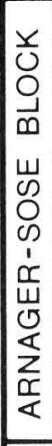 } & & 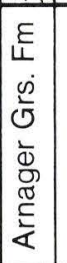 & 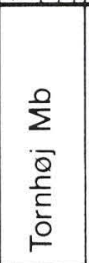 & 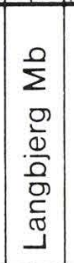 & 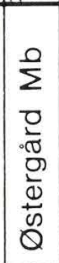 & 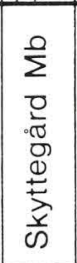 & 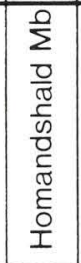 & & & 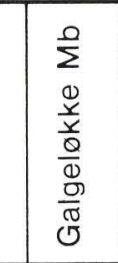 & 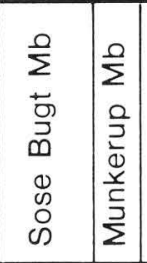 & 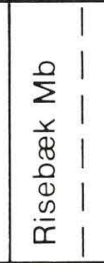 & \\
\hline & $\begin{array}{r}(m) \text { ssau } \\
-y \supset ! 4 \perp \\
\end{array}$ & & $\begin{array}{ll}1 & 0 \\
\end{array}$ & $1 \stackrel{1}{\sim}$ & $\wedge \stackrel{\infty}{\sim}$ & $\exists$ & ¿о & & & 18 & 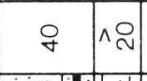 & 181 & \\
\hline & $\begin{array}{r}\text { र60। } \\
-04+7 ! 7 \\
\end{array}$ & 8 & it & 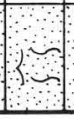 & 8 & 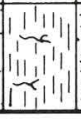 & 1 & & & से & 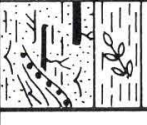 & $\begin{array}{lll}1 & 1 \\
1 & 1 \\
1 & 1 \\
11 & 1 \\
1 & 1 \\
\end{array}$ & \\
\hline \multirow{4}{*}{ 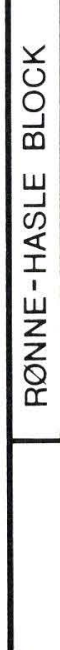 } & & & & & & & & 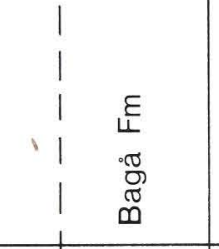 & 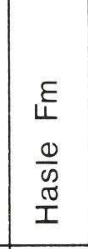 & $\begin{array}{l}\sum_{0}^{0} \\
0 \\
\frac{1}{2} \\
\frac{1}{0} \\
\frac{0}{0} \\
\frac{0}{0} \\
0 \\
0\end{array}$ & $\begin{array}{ll}\sum & 1 \\
\Sigma & 1 \\
0 & 1 \\
0 & 1 \\
0 & 1 \\
0 & 1 \\
0 & 1 \\
0 & \\
\infty & 1\end{array}$ & & \\
\hline & $\begin{array}{r}(\mathrm{w}) \text { ssəu } \\
- \text { - } \supset ! 41 \\
\end{array}$ & & & & & & & $1 \wedge \stackrel{\circ}{N}$ & $\begin{array}{l}1 \\
\dot{\alpha}\end{array}$ & $\begin{array}{l}1 \\
\text { 음음 }\end{array}$ & $\wedge \stackrel{\circ}{\sim} \mid$ & & \\
\hline & $\mid \begin{array}{r}\Lambda 60 \mid \\
-04+!\end{array}$ & & & & & & & $\begin{array}{l}10 \\
101\end{array}$ & a) & $N / v^{2}$ & $\begin{array}{l}f \\
d\end{array}$ & & \\
\hline & & 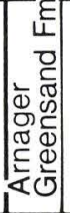 & 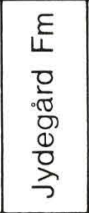 & 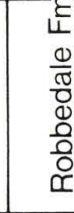 & 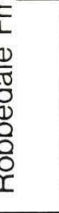 & 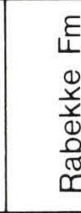 & 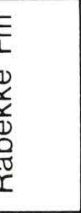 & 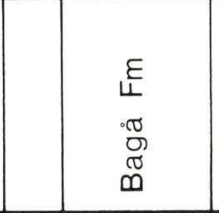 & $\begin{array}{l}\underline{E} \\
\frac{\omega}{9} \\
\frac{\omega}{I} \\
\end{array}$ & & & 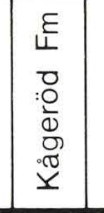 & \\
\hline
\end{tabular}

comprises marginal facies subcropping over a very wide area in the Central North Sea, western Skagerrak, northern Jutland and Scania (see discussion in Bertelsen, 1980, p. 41-42).

The Kågeröd Formation is characteristically de- veloped with a lower arkosic, and an upper clayey part (Troedsson, 1934). A narrow fault bounded outlier on the south coast of Bornholm is here tentatively correlated with the clayey portion and is defined as the Risebæk Member. 


\section{Risebæk Member}

\section{New member}

\section{History}

Sediments referred here to the Risebæk Member are poorly exposed but have been mentioned in much of the literature on the Mesozoic of Bornholm because of their remarkable red and green colours (Bertelsen, 1980 p. 33; Christensen, 1972; Forchhammer, 1837; Grönwall, 1899; Grönwall \& Milthers, 1916; Gry, 1960, 1969, 1977a; Höhne, 1933; Johnstrup, 1899; Rørdam, 1890).

\section{Name}

After the brook Risebæk at the south coast of Bornholm (Fig. 6).

\section{Type area}

The coastal section from north of Risebrk to a point south of the farm Julegård (Fig. 6). The coast is characterized by numerous landslides where different parts of the member are exposed. The degree of exposure varies considerably as a result of continuous sliding.

\section{Thickness}

Not well known. Gry (1977a) suggests a minimum thickness at Risebæk of at least $60-70 \mathrm{~m}$, but the total thickness may be considerably higher.

\section{Lithology}

Red, green and grey green clay and silt with calcitic or siliceous caliche nodules, which in some cases have been reworked and deposited as isolated pebble conglomerates or as basal channel lags. The clay alternates with beds of white or greenish sandstone. Light trough cross-bedded sandstone and greenish bioturbated siltstone occur adjacent to the variegated clay in the low coastal cliff west of Risebæk. The stratigraphic position of these beds is uncertain and they may belong to the Homandshald Member of the Rabekke Formation.

\section{Boundaries}

The lower boundary of the Risebæk Member is not known, but the bright variegated colours distinguishes it from all other rocks on Bornholm. The member is overlain by dominantly dark carbonaceous clay of the Munkerup Member, Rønne Formation (Höhne, 1933), and the upper boundary is described in more detail on p. 12 under this formation.

\section{Distribution}

The Risebæk Member is known only with certainty from the type area (Fig. 6). According to Gry (in

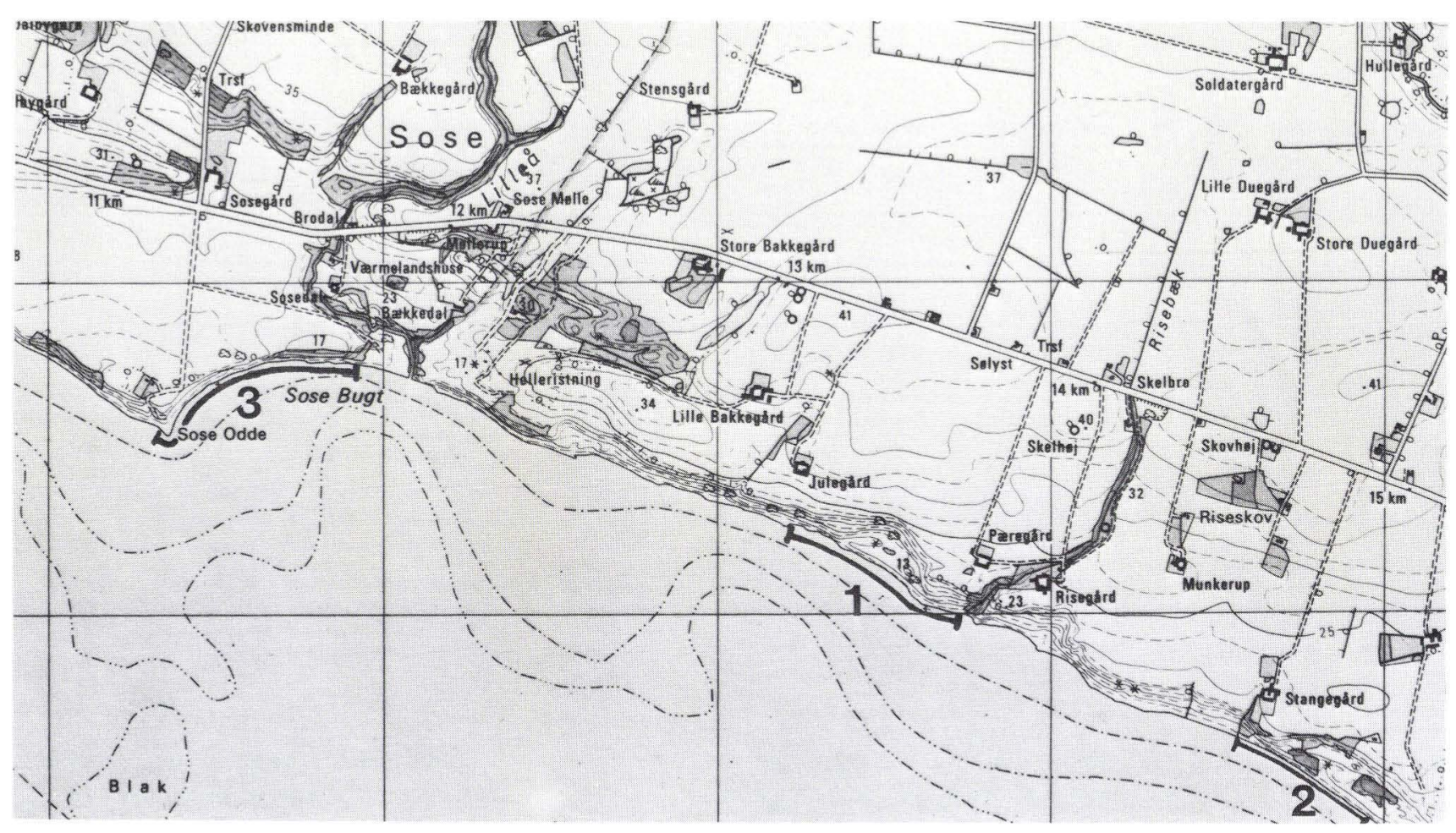

Fig. 6. Topographic map of the south coast of Bornholm from Sose Odde to Risebæk (see fig. 3). 1 type area of the Risebæk Member, 2 type locality of the Munkerup Member, 3 type locality of the Sose Bugt Member. Section of map sheet 1812 III NV Rønne in the scale 1:25000. Reproduced with the permission A400/76 of the Geodetic Institute. 
Bertelsen, 1980 p. 33) red bed sequences are known from shallow wells at Sorthat on the west coast (Fig. 20), but it is highly questionable if these sediments can be referred to the Risebæk Member (H. Gry pers. comm. 1981).

\section{Geological age}

Sparse ostracod data seem to indicate an Early to Middle Keuper (Late Ladinian - Carnian) age (Christensen, 1972).

\section{Bornholm Group}

New group

Name

After the island of Bornholm (Fig. 1).

\section{Thickness}

More than $720 \mathrm{~m}$ in areas of maximum thickness (Gry, 1960).

\section{Lithology}

The group consists of rapidly alternating sand and clay with subordinate layers of clay-ironstone, coal and conglomerates of debris flow origin. The basal Rønne Formation comprises fluviatile sand and clay with rootlet beds and thin coal seams, lacustrine clay and tidal flat sand and clay. It is followed by the marine, sandy Hasle Formation, which is overlain by the main coal-bearing unit, the Bagå Formation.

\section{Boundaries}

The group oversteps onto a variety of older rock types ranging from the Precambrian gneissic basement over Lower Palaeozoic sandstones and mudstones to variegated sediments of the Triassic Risebæk Member, Kågeröd Formation. It is overlain by ferruginous coarse-grained sandstone, kaolin-rich sand and grey clay of the Homandshald Member, Rabekke Formation.

\section{Distribution}

The group is only exposed along the central south coast and southern west coast of Bornholm and in scattered clay pits immediately inland of the coastline.

It is furthermore expected to be present in the offshore subsurface region around Bornholm, but at present nothing detailed is known about the stratigraphic nature of these areas (see Andersen, Larsen
\& Platou, 1975; Kögler \& Larsen, 1979; Kumpas, 1980). The Middle Jurassic Bagå Formation resembles the contemporaneous Eriksdal Formation in Scania (see Norling \& Skoglund, 1977; Koch, 1979), but the two units probably never formed a continuous body. The Baga Formation is furthermore of a more fluviatile nature than the Eriksdal Formation which possesses more marine features, and the two units are thus placed in two different formations.

\section{Geological age}

The basal beds of the group contain Lower Lias alpha (Hettangian) spores, while the top beds are of Bajocian - Bathonian Age (Gry, 1969).

\section{Subdivisions}

The group is subdivided into the Rønne (base), Hasle and Bagå (top) Formations.

\section{Rønne Formation}

\section{New formation}

\section{History}

Parts of this formation have been described by many workers under different names. Malling (1914) and Milthers (1930) were the first to group together the sediments now defined as the Rønne Formation. Milthers briefly described the "Lower Limnic Part" ("Nedre Limniske Afdeling") of the presumed Rhaetic - Liassic sediments of Bornholm, in which he also included some parts of the present Bagå Formation. Later workers followed his scheme until the work by Gry (1969) where the formation was referred to as the "Lower Coal-bearing Series".

Name

From the town Rønne on the southwest coast of Bornholm (Fig. 3).

\section{Type area}

The southwest coast of Bornholm between Sønderborg (Fig. 7) and Næbbe Odde (Fig. 8) where the upper parts of the formation are exposed.

\section{Reference locality}

The south coast of Bornholm in Sose Bugt (Fig. 6) where the lower parts of the formation are or have been exposed.

\section{Thickness}

The thickness is estimated to more than $350 \mathrm{~m}$ (Gry, $1960,1969)$, but it seems to be very variable, and in 


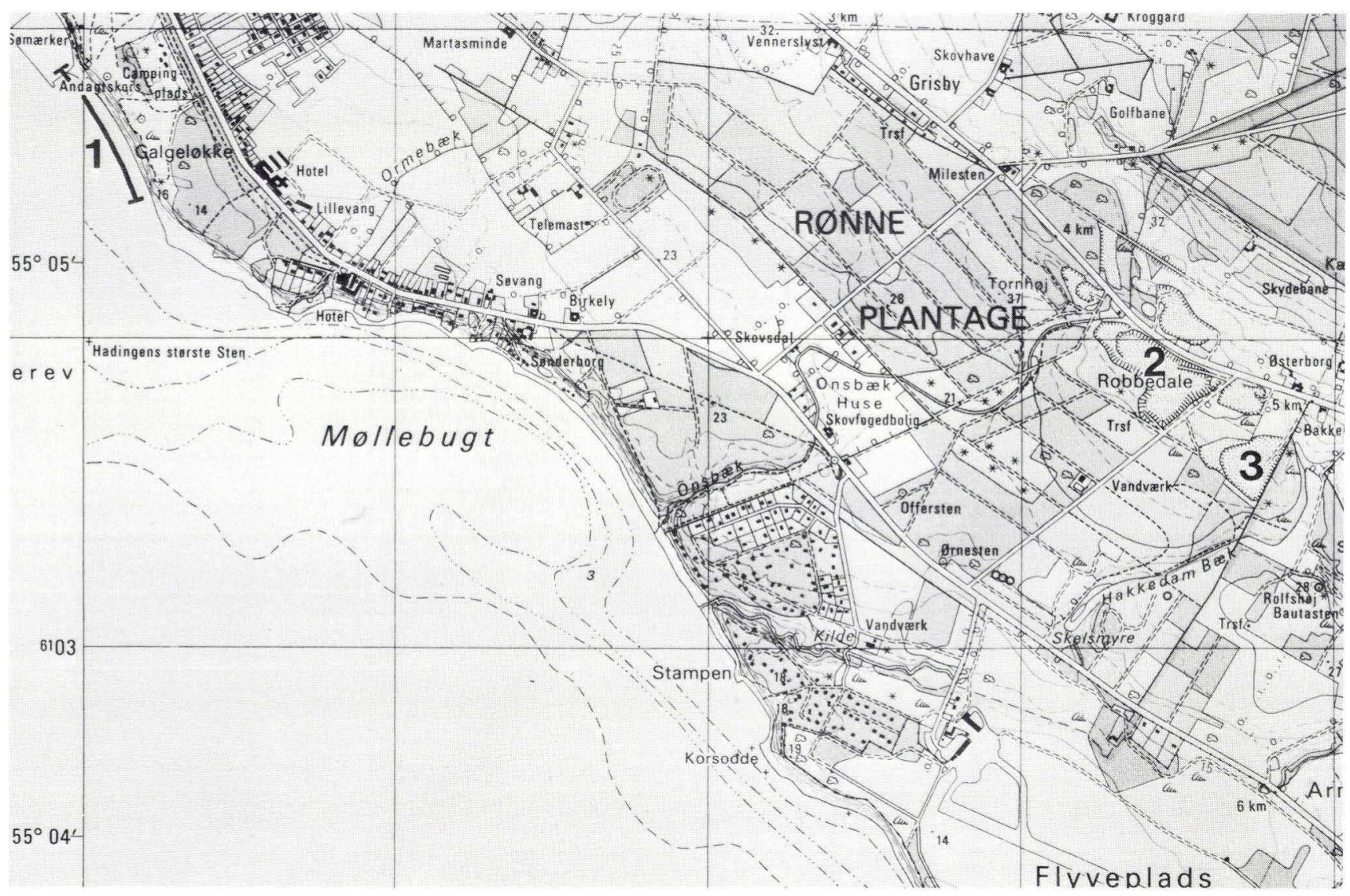

Fig 7. Topographic map of the southwest coast of Bornholm southeast of Rønne (see fig. 3). 1 type locality of the Galgeløkke Member, 2 A/S Carl Nielsens sand pit, type locality of the Robbedale Formation, and of the Langbjerg Member, 3 Østerborg sand pit, type locality of the Østerborg Member. Section of map sheet 1812 III NV Rønne in the scale 1:25000. Reproduced with the permission A400/76 of the Geodetic Institute.

the type area the lower boundary is not exposed, so a greater thickness is possible.

\section{Lithology}

The formation comprises a wide variety of lithologies

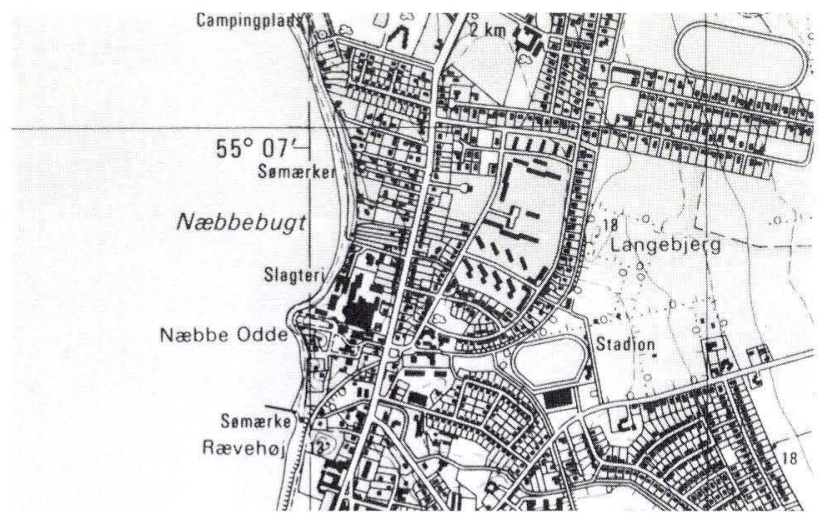

Fig. 8. Topographic map of the west coast of Bornholm, north of Rønne (see fig. 3). Section of map sheet 1812 III NV Rønne in the scale 1:25000. Reproduced with the permission A400/76 of the Geodetic Institute. including autochtonous coal beds, laminated or massive mud, cross-laminated sand, heterolithic sand and mud and occasionally large-scale cross-bedded sand. The sediments are essentially unconsolidated except for local thin ferruginous beds and lenses. Carbonaceous debris occur in abundance and plant fossils are frequent, but body fossils are rare. Trace fossils are locally abundant.

\section{Boundaries}

The lower boundary is marked by a change from red, green and variegated clay and greenish sandstone devoid of carbonaceous detritus of the Risebæk Member, Kågeröd Formation to light and dark grey to black clay with abundant carbonaceous material and subordinate sand (Fig. 9). The formation rests in other areas on indurated Cambrian quartzitic sandstone. The upper boundary to the Hasle Formation is taken where the unconsolidated interbedded sand and clay with carbonaceous detritus change to more indurated limonitic brown sandstone with abundant marine fossils. 


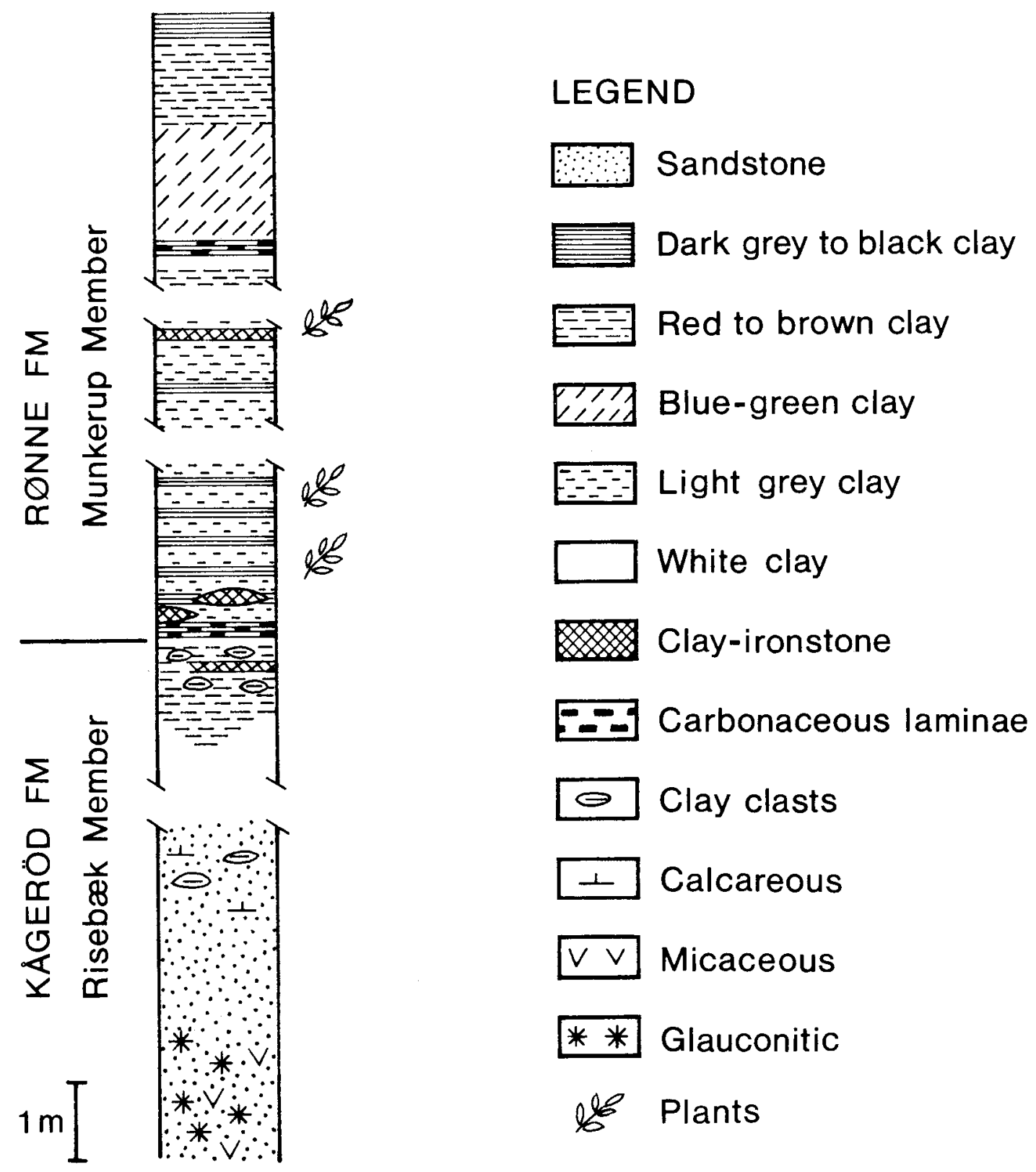

Fig. 9. Section across the boundary between the Risebæk and Munkerup Members. Position indicated by 2 in fig. 6 . Based on data in Höhne (1933).

\section{Distribution}

The formation crops out only along the coast line on the Rønne-Hasle and Arnager-Sose blocks, and drillings have established its presence a short distance inland. The formation also occupies a small coastal area at Munkerup, east of the reference locality (Fig. $6)$.

\section{Geological age}

Lower Jurassic. The base of the formation contains a Thaumatopteris flora of basal Liassic (Hettangian) age (Harris, 1937), and spores from various parts of the formation have indicated Early Jurassic ages (Gry, 1969). The age of the uppermost part of the formation is not younger than Early Pliensbachian, the age of the overlying Hasle Formation.

\section{Subdivision}

The Rønne Formation is here subdivided into the Munkerup Member (base), Sose Bugt Member and Galgeløkke Member (top). 


\section{Munkerup Member}

New member

\section{History}

Clays belonging to this member have been known for centuries under the names Vellengsby clay and Munkerup clay. It has been excavated for local use in potteries or brickworks, and numerous small pits have been in existence. At present they are all overgrown, and in places water filled, so the following description is based on the literature. The sediments have been described by many workers (e.g. Forchhammer, 1837; Grönwall, 1899; Höhne, 1933; Gry, 1969), and the fossil flora has been intensively studied (Bartholin, 1894; Hjorth, 1899; Harris, 1937).

\section{Name}

From the farm Munkerup on the south coast of Bornholm (Fig. 6). The name Munkerup clay has long been established for the clays at this locality.

\section{Type locality}

The type locality is situated at the coast at Munkerup (Fig. 6), where Höhne (1933) described a composite section through the lower part of the member where the lower boundary can be established (Fig. 9).

\section{Reference section}

The borehole DGU file No. 246.208 (depth 5.6-13.4 m.b.s.) situated $1.5 \mathrm{~km}$ northwest of Vellensbygaard (Fig. 10) is established as reference section for the contact between the Cambrian Nexø Sandstone Formation and the Munkerup Member.

\section{Thickness}

According to Gry (1969) the Munkerup Clay has a thickness of $20 \mathrm{~m}$, but as the upper boundary is unknown, it may be somewhat more.

\section{Lithology}

The dominant lithology is grey to black clay with subordinate thin bands of red, brown and white clay, and sandstone. Locally the clay is cemented to reddish clay-ironstone, and some clay-clast conglomerates are noted in the lower part (Höhne, 1933). The sand is only briefly described as very fine-grained white to yellowish, with ferruginous concretions of cm-size or with carbonaceous detritus (Gry, 1969; Höhne, 1933). Carbonaceous detritus and plant fossils are abundant in the clay, and occasionally form cm-thick coal-laminae. Grönwall (1899) mentions the existence of poorly preserved bivalves in a thin bed, but this has not been recognized later.

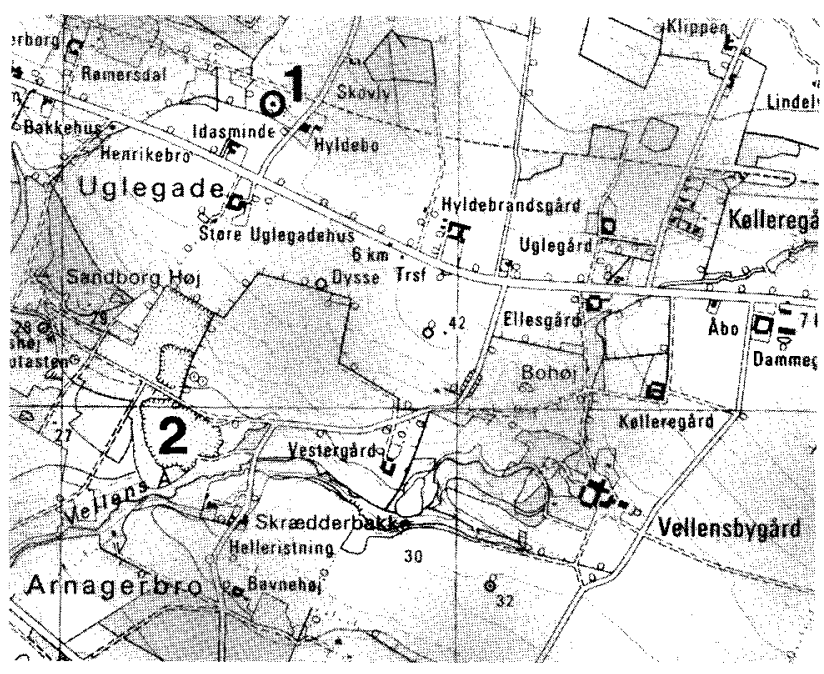

Fig. 10. Topographic map of the Vellensby area, south-central Bornholm (see fig. 3). 1 position of boring D.G.U. file no. 246.208, 2 Skrædderbakke sand pit.

Section of map sheet 1812 III NV Rønne in the scale 1:25000. Reproduced with the permission A400/76 of the Geodetic Institute.

\section{Boundaries}

The lower boundary of the Munkerup Member is identical to the lower boundary of the Rønne Formation, and is described in the preceding section. The upper boundary is not exposed, and has not been described in sufficient detail to allow a precise definition, but it is suggested that the higher sand-content in the overlying Sose Bugt Member is used as a distinguishing criterion.

\section{Distribution}

The Munkerup Member is restricted to a small area at the coast at Munkerup, and in a narrow strip from the coast east of Lilleå inland towards northwest. An apparently isolated occurrence is found on the minor fault block at Vellensby (Fig. 2).

\section{Geological age}

Harris (1937) determined the plant fossils as belonging to the Thaumatopteris flora of basal Liassic (Hettangian) age. Gry (1969) confirmed this by finding spores of the species Nathorstisporites hopliticus Jung and Verrutriletes franconicus Jung in the Vellengsby and Munkerup clays.

Fig. 11. Explanation of symbols used in the measured sections. $\rightarrow$ 
LITHOLOGY

Muddy sand

$\equiv$ Clay

Silt

Sand

a. Pebbly sand

Heterolithic clay $(50 \%)$

and sand $(50 \%)$

Coal

Ferruginous cement

- Pyritic concretions

$\because$ Carbonaceous detritus

\section{SEDIMENTARY STRUCTURES}

\section{SAND}

$\because$ Structureless

$\equiv$ Faint horizontal lamination

Horizontal lamination

$\nVdash \Psi$ Small-scale cross-lamination

« Small-scale herringbone cross-lamination

Large-scale planar cross-bedding

Large-scale herringbone

cross-bedding

Large-scale trough cross-bedding

\section{HETEROLITHS}

$\because$ Mud partings

$\uparrow$ Flaser lamination

$\approx$ Wavy lamination

$\Delta \Delta$ Lenticular lamination

Rhythmic bedding

\section{SILT AND CLAY}

\section{Structureless}

望 Lamination
SECONDARY SEDIMENTARY STRUCTURES

[ivy Water-escape structure

Ev Load structure

造政 Slump structure

Ere.e. Erosional surface

\section{BIOGENIC STRUCTURES}

$\iint$ Degree of bioturbation

$\varnothing$ Planolites

ᄎ Chondrites

IIII Skolithos

UU Arenicolites

ophiomorpha

a:s, Ophiomorpha like burrows

U J-and $\mathrm{Y}$ - shaped burrows

\& Backfill

$\lambda h \lambda \lambda$ Rootlets

FOSSILS

- Ammonite

$\Theta$ Bivalve

\& Gastropod

es Plants

Wood (stems and branches)

\section{DIRECTIONAL FEATURES}

$K$ Palaeocurrent direction

\. Wave ripple oscillation

\Fining upwards sequence

$\rrbracket$ Coarsening upwards sequence 


\section{Sose Bugt Member}

\section{New member}

\section{History}

The sediments from the Sose Bugt Member have been described from the type locality by Grönwall \& Milthers (1916) who mention the occurrence of coal beds on the sea-floor in Sose Vig (Vig = bay in English) and very fine-grained sand and greyish clay in the coastal cliffs. The same observations were made by Höhne (1933), who measured the section in some detail, and by Gry (1969) who added that the sediments contain abundant plant-debris and thin coal seams. Gry also mentioned that the sediments extend inland, where they were found in boreholes below a thin Quaternary cover. Rolle $(1977,1978)$ measured the type section and described and interpreted the facies associations in terms of their sedimentary environments.

Name

From the type locality Sose Bugt on the south coast of Bornholm (Fig. 6).

\section{RØNNE FORMATION Sose Bugt Member}

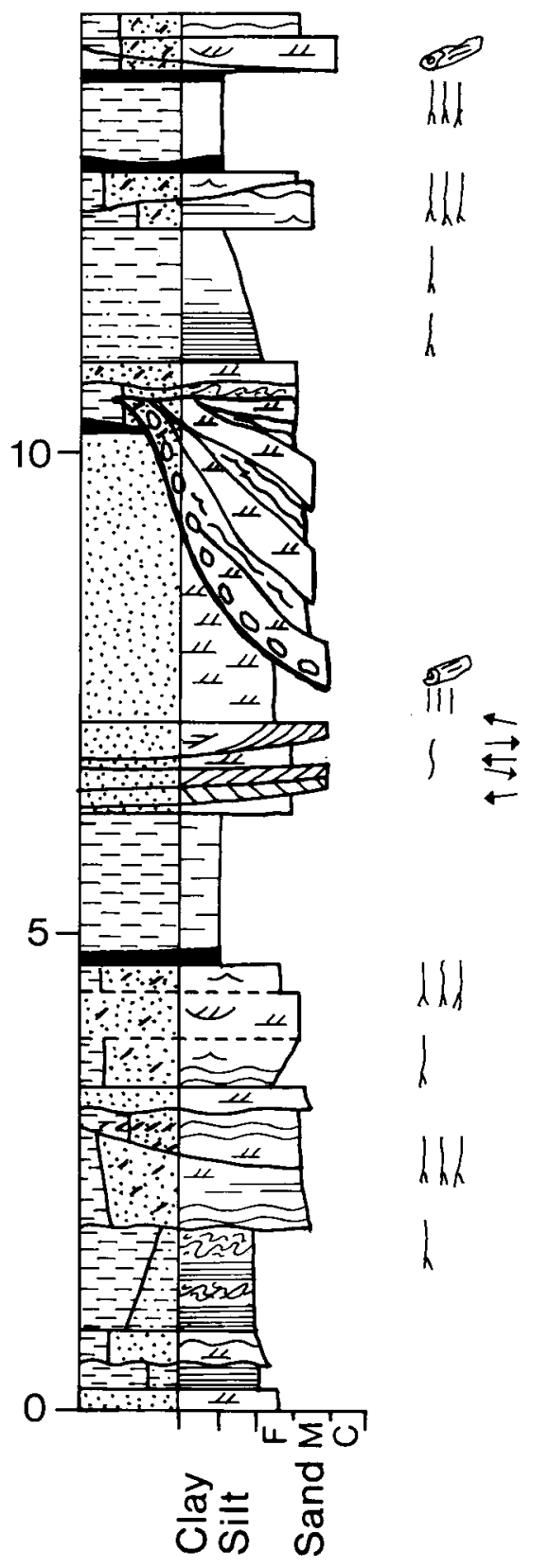

Fig. 12. Type section of the Sose Bugt Member. Position indicated by 3 in fig. 6. Symbols shown in fig. 11. Measured by F. Rolle in 1977. 
Type locality

The coastal cliff-section between Sose Odde and Lilleå on the south coast of Bornholm (Figs. 6, 12).

\section{Thickness}

The thickness measured in the type section is $26 \mathrm{~m}$, but as the lower boundary is not exposed, a greater thickness may be present. Gry (1969) gives a total thickness of $60 \mathrm{~m}$ for the Munkerup and Sose Bugt Members, so the Sose Bugt Member probably attains a thickness of about $40 \mathrm{~m}$ in the type area.

\section{Lithology}

Dominated by rapidly alternating beds of finegrained cross-laminated sand, often with abundant carbonaceous detritus, and thin beds of grey laminated clay or interlaminated clay and silt (Fig. 13). Rootlet horizons and thin coal-seams are frequent. In the middle part small- and large-scale cross-bedded medium-grained sand and a thick bed of very well sorted micaceous fine-grained sand with abundant
Skolithos occurs. At the type locality a large channel filled with alternating sand and heteroliths cuts into these sediments (Fig. 14). The lithology in the upper part comprises wavy and lenticular laminated silt and grey clay with abundant trace fossils.

\section{Boundaries}

The lower boundary is not exposed, but the distinction between the Munkerup and Sose Bugt Members should be made on the basis of the more frequent sand beds in the latter. The upper boundary is exposed west of Sose Odde, where heterolithic clay dominated sediments are overlain by well-sorted, largescale trough cross-bedded and horizontally laminated sandstone of the Galgeløkke Member, which in contrast to the sediments of the Sose Bugt Member are moderately hardened and brown coloured.

\section{Distribution}

The Sose Bugt Member is known from the type locality and a short distance inland towards the north-
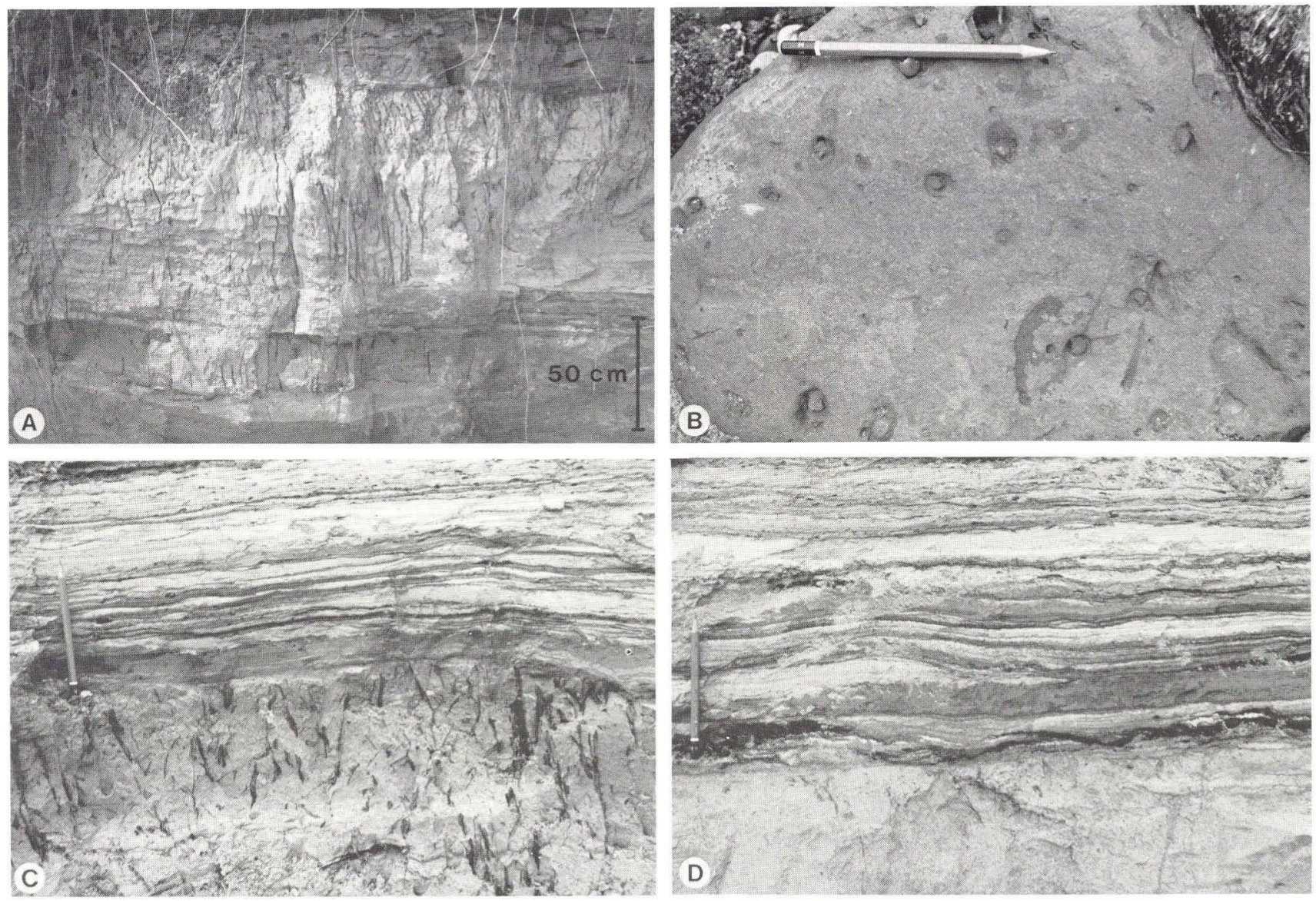

Fig. 13. Lithological details from the Sose Bugt Member. A: Rootlet bed in the basal Sose Bugt Member, Sose Bugt immediately west of Lilleå (see fig. 6). B: Upper surface of clay-ironstone with Diplocraterion from the upper part of the Sose Bugt Member at Sose Odde (see fig. 6). C and D: Fine-grained sandstone with rootlets in $\mathrm{c}$ form small topographic hills while rootlets are absent from the same bed where it forms a depresson (d). Lateral distance between the two localitites $10 \mathrm{~m}$. Lower part of the Sose Bugt Member, Sose Bugt immediately west of Lilleå (see fig. 6). 


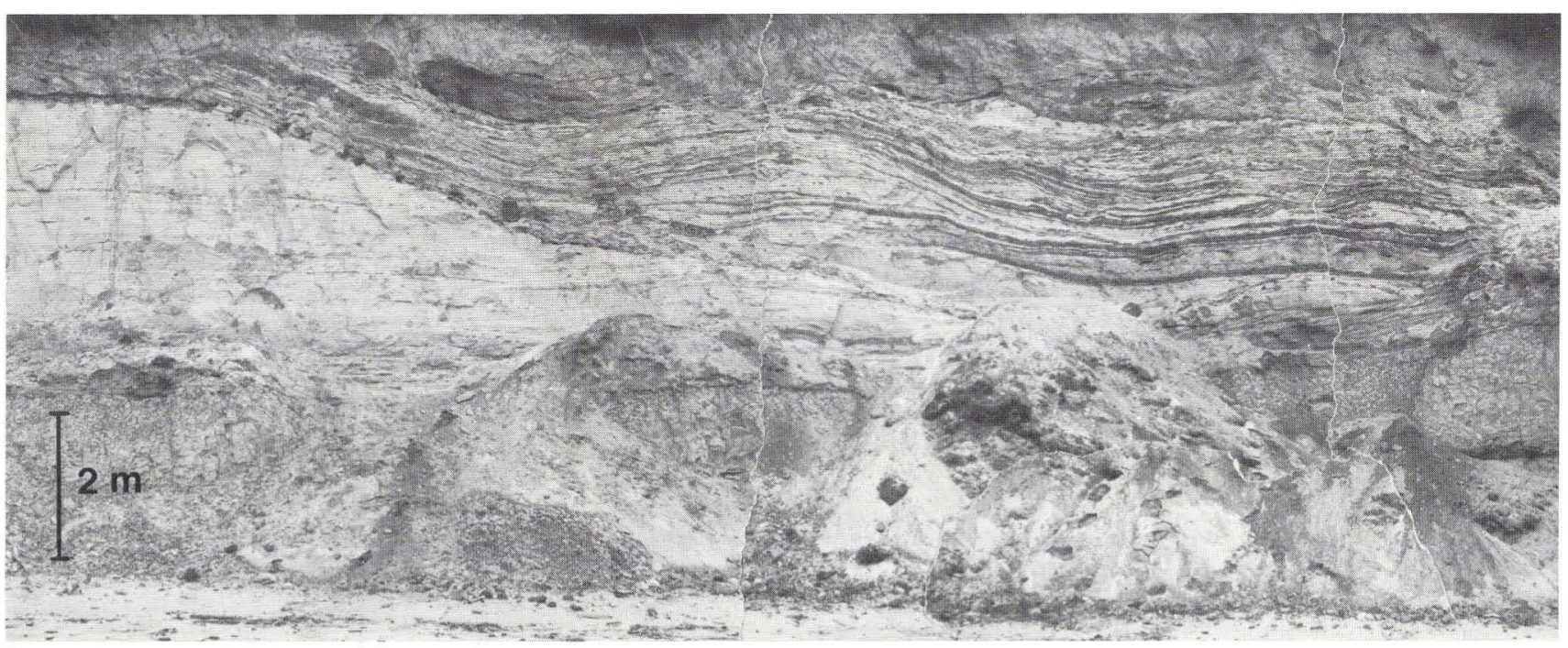

Fig. 14. Channel in the middle part of the Sose Bugt Member cutting down into fine-grained marine sand. The channel fill has a basal lag of clay clasts, coal and wood fragments, which pass upwards into alternating cross-bedded sand and heterolithic sand and clay. Sose Bugt, west of Lilleå (see fig. 6).

west. The sediments on the coast east of Ormebæk near Rønne (Fig. 7) are included in this member because of their stratigraphic position and great lithologic similarity with the type section.

\section{Geological age}

Gry (1969) dated the sediments as Lias alpha (Hettangian to lowermost Sinemurian) on the basis of the spore content.

\section{Galgeløkke Member}

\section{New member}

\section{History}

Grönwall \& Milthers (1916) described the occurrence of very fine-grained sand with subordinate clay and minor coal seams along the southwest coast of Bornholm between Ormebæk and Næbbe Odde (Figs. 7, 8). They noted that the sediments were essentially unfossiliferous, except for an occurrence of the bivalve Cardinia follini Lundgren at Galgeløkke and plant fossils of the genus Dictyophyllum at Ormebæk. Höhne (1933) described sections from many localities, the most comprehensive of which were the clay pits of Rønne Lervarefabrik, where the upper boundary of the member can be established. All the inland clay pits described in the literature are now overgrown or water filled. Gry (1969) summarized the localities and published a map of the distribution of the various lithologies. He did not, however, formalise the stratigraphy. Sellwood (1972,
1975 ) interpreted the upper part of the type section as a regressive tidal flat sequence, and this was expanded on the basis of better exposures by Rolle (1977, 1978).

\section{Name}

From Galgeløkke on the southwest coast of Bornholm (Fig. 7).

\section{Type locality}

The coastal cliff at Galgeløkke (Figs. 7, 15).

\section{Thickness}

The thickness of the Galgeløkke Member is uncertain, but seems to be quite variable, and Gry (1969) gives thicknesses between $150 \mathrm{~m}$ and $210 \mathrm{~m}$ for the sequence between the bed with Cardinia follini and the Hasle Formation, and this corresponds roughly to the extent of the Galgeløkke Member.

\section{Lithology}

The lithology is very variable, but is dominated by light grey to white or yellowish, generally unconsolidated cross-laminated fine-grained sand or heterolithic wavy and flaser-laminated sand and clay, especially in the lower part of the member. Subordinate beds of large-scale cross-bedded medium to coarsegrained sand occurs (Figs. 16, 17, 18). Thin autochtonous coal beds overlying dark clay with rootlets are found as well as local accumulations of carbonaceous detritus, but they are not common. Dispersed carbonaceous fragments and organic matter occur throughout. The clay content is generally moderate, 

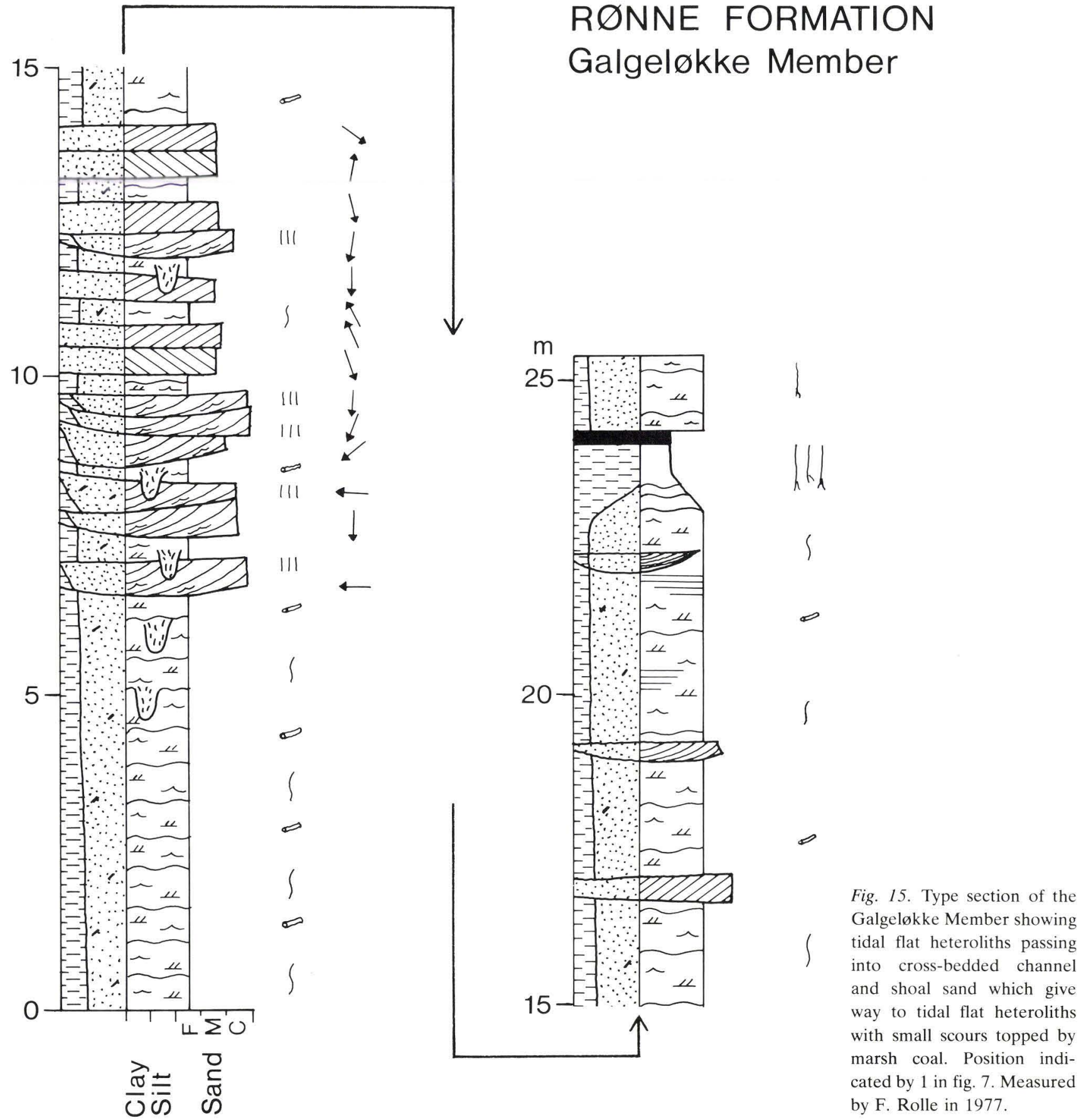

but some beds up to $50 \mathrm{~cm}$ thick occur. Rare agglutinating foraminifers are recorded (Sellwood, 1972) and one bed with Cardinia follini is known, but otherwise the sediments do not contain body fossils. Trace fossils of Skolithos and Planolites types are only locally abundant (Figs. 17d, 18c) (Rolle, 1978).

\section{Boundaries}

The lower boundary to the Sose Bugt Member is placed where the clay dominated sediments are overlain by rusty brown fine-grained large-scale trough cross-bedded sandstone. The boundary is exposed west of Sose Odde. The sandstones have, however, not been biostratigraphically dated. They are somewhat reminiscent of the Hasle Formation, but they have never yielded normal marine faunas with ammonites characteristic of this formation. They are overlain by heterolithic sediments typical of the Galgeløkke Member, which seems to be overlain by the Tithonian? - Lower Berriasian Homandshald Member. The Middle Jurassic Bagå Formation is totally absent. It can thus be concluded that the 


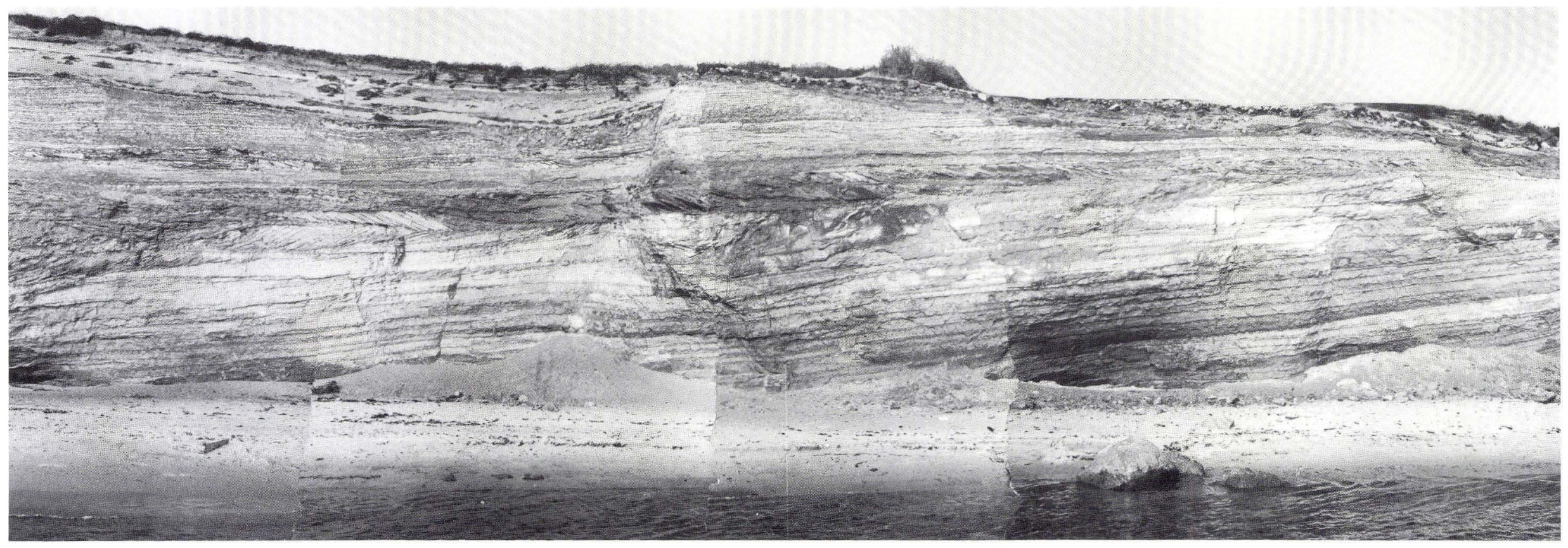

Fig. 16. Photomosaic showing the lower part of the section in fig. 15. Note the rhythmic bedding in the lower heterolithic part, the bimodality in palaeocurrents of the overlying cross-bedded sandstone, their bundle-wise upbuilding, and numerous pause planes (= reactivation planes). Cliff height about $10 \mathrm{~m}$ 

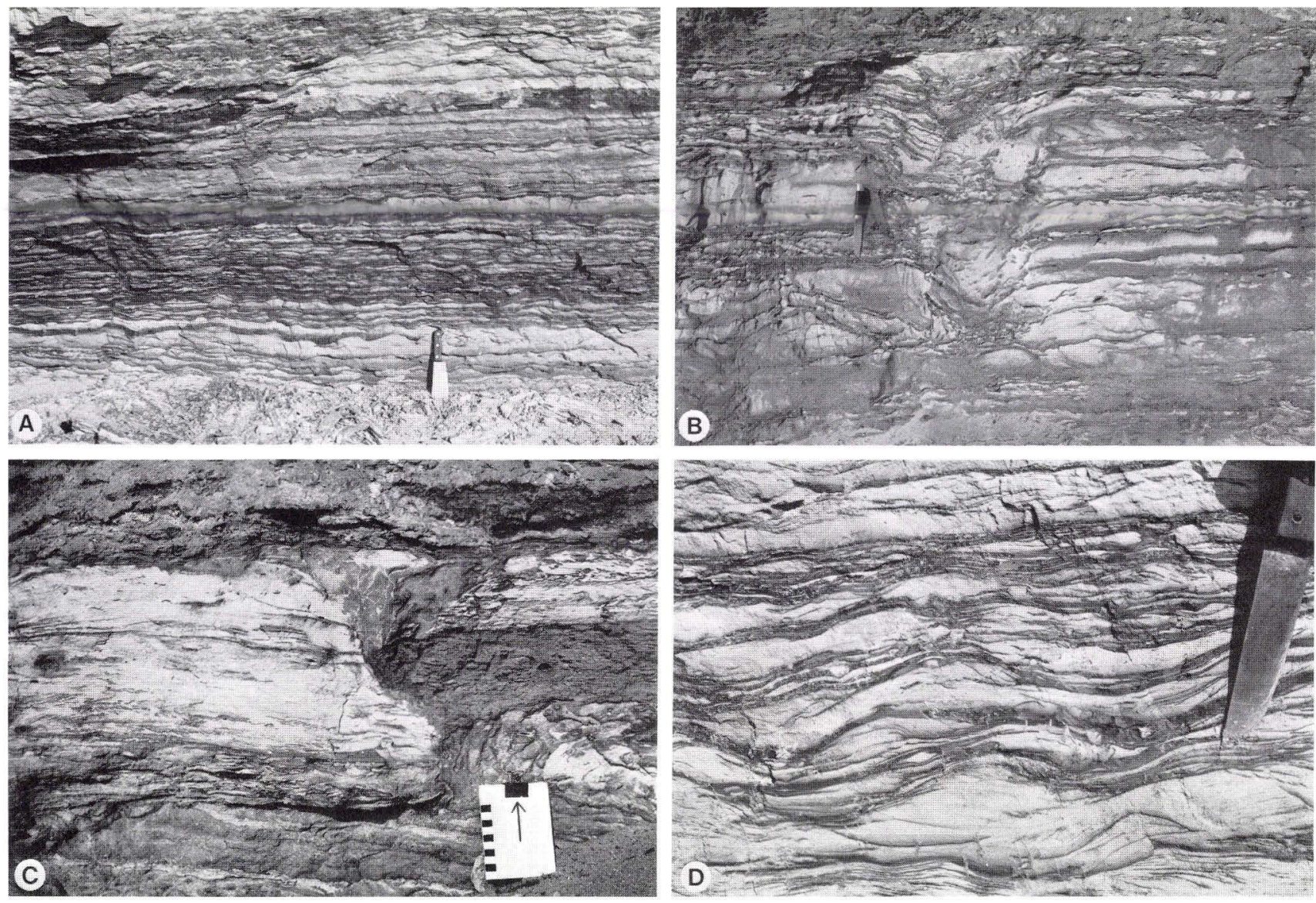

Fig. 17. Lithological details of the lower part of the Galgeløkke Member, type section. A: Flaser, wavy and lenticular laminated heteroliths B: Water escape structure in sandy heteroliths. C: Erosional undercutting of clay bed. D: Heterolith showing bimodal palacocurrents, loaded ripples and rare Planolites.

sandstones west of Sose Odde with little doubt belong to the basal part of the Galgeløkke Member. This boundary will be approximately at the level of the horizon with Cardinia follini described by Gry (1969).

The upper boundary to the Hasle Formation is taken at the first occurrence of marine macrofossils in a grey brown sandstone as described by Höhne (1933 pp. 11-12) from the clay pit of Rønne Lervarfabrik.

\section{Distribution}

The Galgeløkke Member is present in the Rønne area, a small area north of Hasle, and west of Sose Odde (Fig. 2).

\section{Geological age}

Lower Jurassic, Sinemurian. The age is established on the basis of the stratigraphic position of the member between the Sose Bugt Member of Lias alpha age (Hettangian to lowermost Sinemurian) and the Hasle Formation of Lias gamma age (Lower Pliensbachian) (Gry, 1969).

\section{Hasle Formation}

\section{New formation}

\section{History}

Sediments belonging to the Hasle Formation have been known and studied for the last 150 years, but different outcrops have been given local names, which to a large extent have been retained in the literature even after Malling $(1914,1920)$ realized that they belonged to the same unit which he termed "The Marine Lias of Bornholm" ("den marine Lias på Bornholm"). The outcrops in the Hasle area (Figs. 2,19) are known as the Hasle Sandstone (Malling, 1911), while the exposures north of Rønne have been given the names "The Green Systems" ("De grønne Systemer") (Jespersen, 1865) or "Jespersen's arc-systems" ("De Jespersenske Buelag") (Malling, 1914) because of the arcuate shape of the outcrop. South-east of Rønne the formation crops out in a small area at Korsodde (Fig. 7), where different fossiliferous beds were given different names such as 

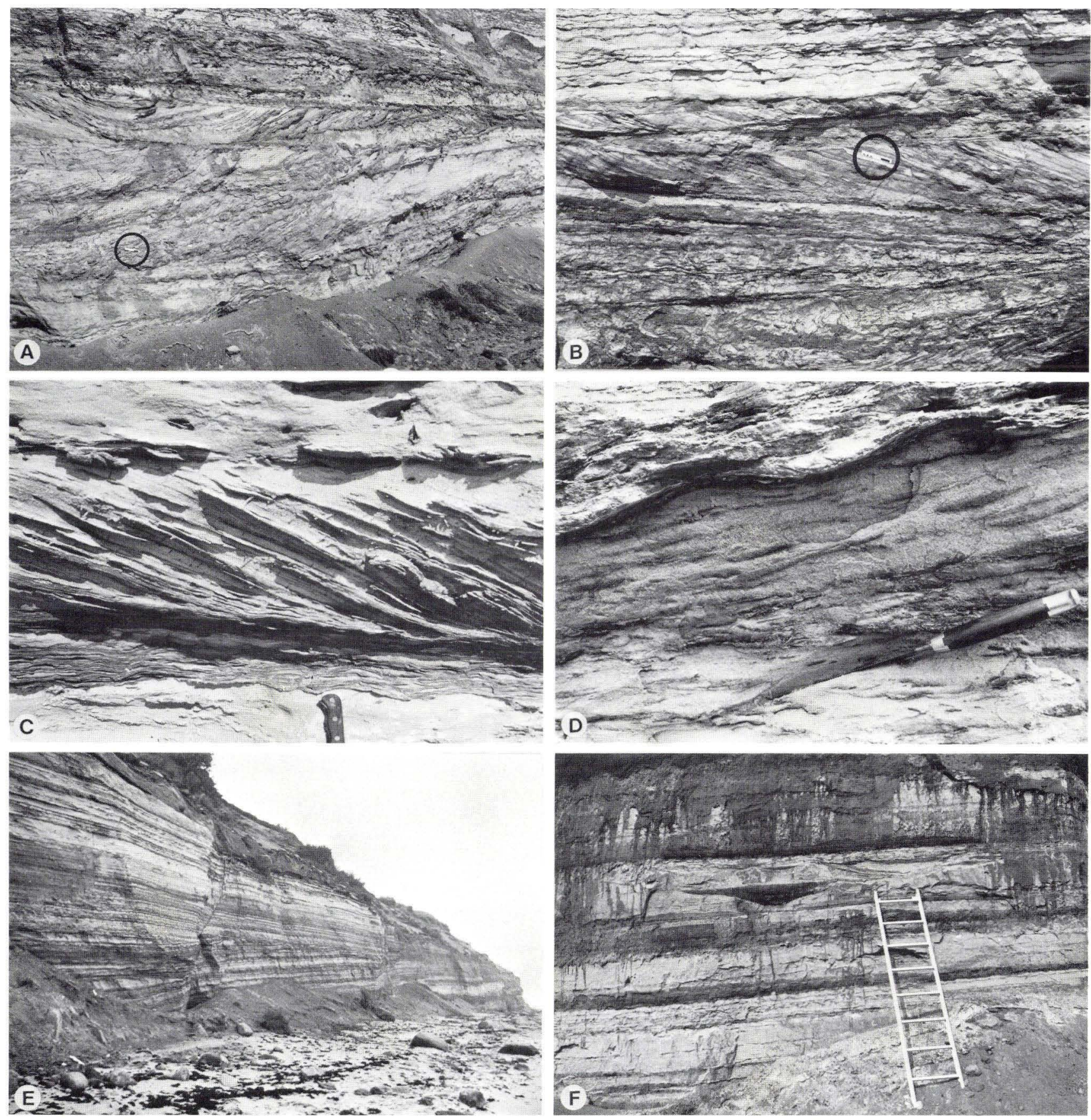

Fig. 18. Lithological details from the cross-bedded part of the Galgeløkke Member, type section. A: Tidal channel filled from the right and along the axis by cross-bedded sand with bundle-wise upbuilding of mud draped foresets. B: Wedge shaped cross-sets separated by mud draped pause plane, overlain by laminated heterolith. C: Bundle-wise upbuilt mud draped foresets passing into mud draped rippled bottom sets. Skolithos forming right angles to the foresets indicate repeated interruptions in sedimentation. D: Mud draped ripples migrating up a large foreset reflecting difference in magnitude of two opposing tidal currents. E: Angular unconformity within the upper heterolithic sequence of the Galgeløkke Member, type section. The unconformity is probably not of tectonic origin, but rather reflects low-amplitude topographic relief in the original tidal flats. F: Symmetrical scours interpreted as small tidal creeks in the upper heterolithic part of the Galgeløkke Member type section. Ladder height $2.5 \mathrm{~m}$.

e.g. the Myoconcha Bed ("Myoconcha-Bænken") (Malling \& Grönwall, 1909). From these localities an abundant marine fauna has been collected and described by Forchhammer (1837), Lundgreen (1879),
Malling \& Grönwall (1909), Malling (1911, 1914, 1920), and Höhne (1933). The "Marine Lias gamma Beds" of Gry (1969) are equivalent to the proposed Hasle Formation. 


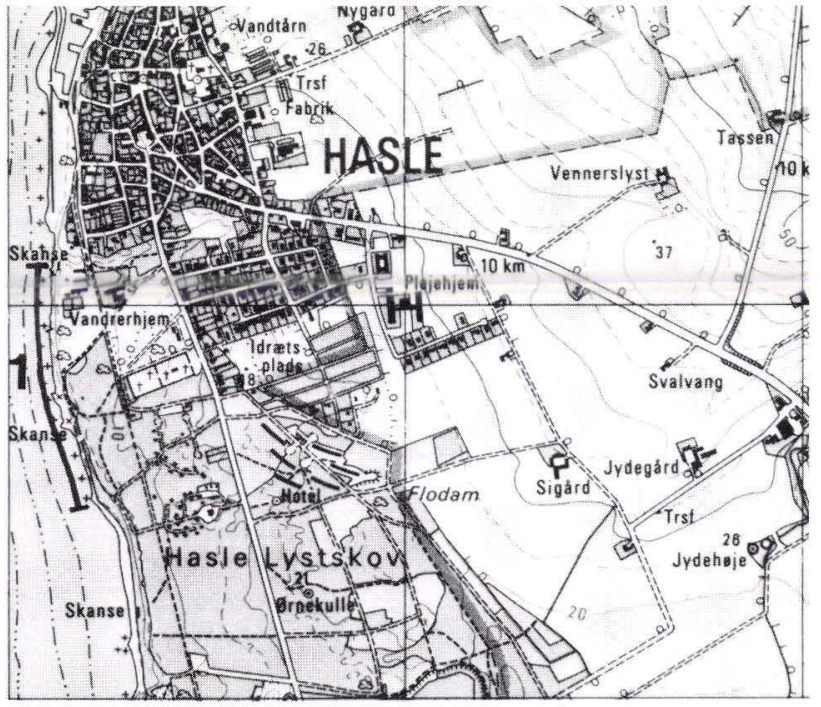

Fig. 19. Topographic map of the Hasle area, west coast of Bornholm (see fig. 3). 1 type locality of the Hasle Formation. Section of map sheet 1812 IV SV Hasle in the scale 1:25000. Reproduced with the permission A400/76 of the Geodetic Institute.
Name

From the town Hasle on the west coast of Bornholm (Fig. 3).

\section{Type locality}

The coastal area south of Hasle, where the lithology of the sediments is well displayed in low cliff sections (Fig. 19).

\section{Reference area}

The coastal area NW of Korsodde (Fig. 7).

\section{Thickness}

Gry (1969) has determined the thickness to vary from $80 \mathrm{~m}$ in the Rønne area to approximately $110 \mathrm{~m}$ in the Sorthat area (Fig. 20).

\section{Lithology}

The Hasle Formation is dominated by limonitic sandstone which is fine-grained, firm to hard, with a

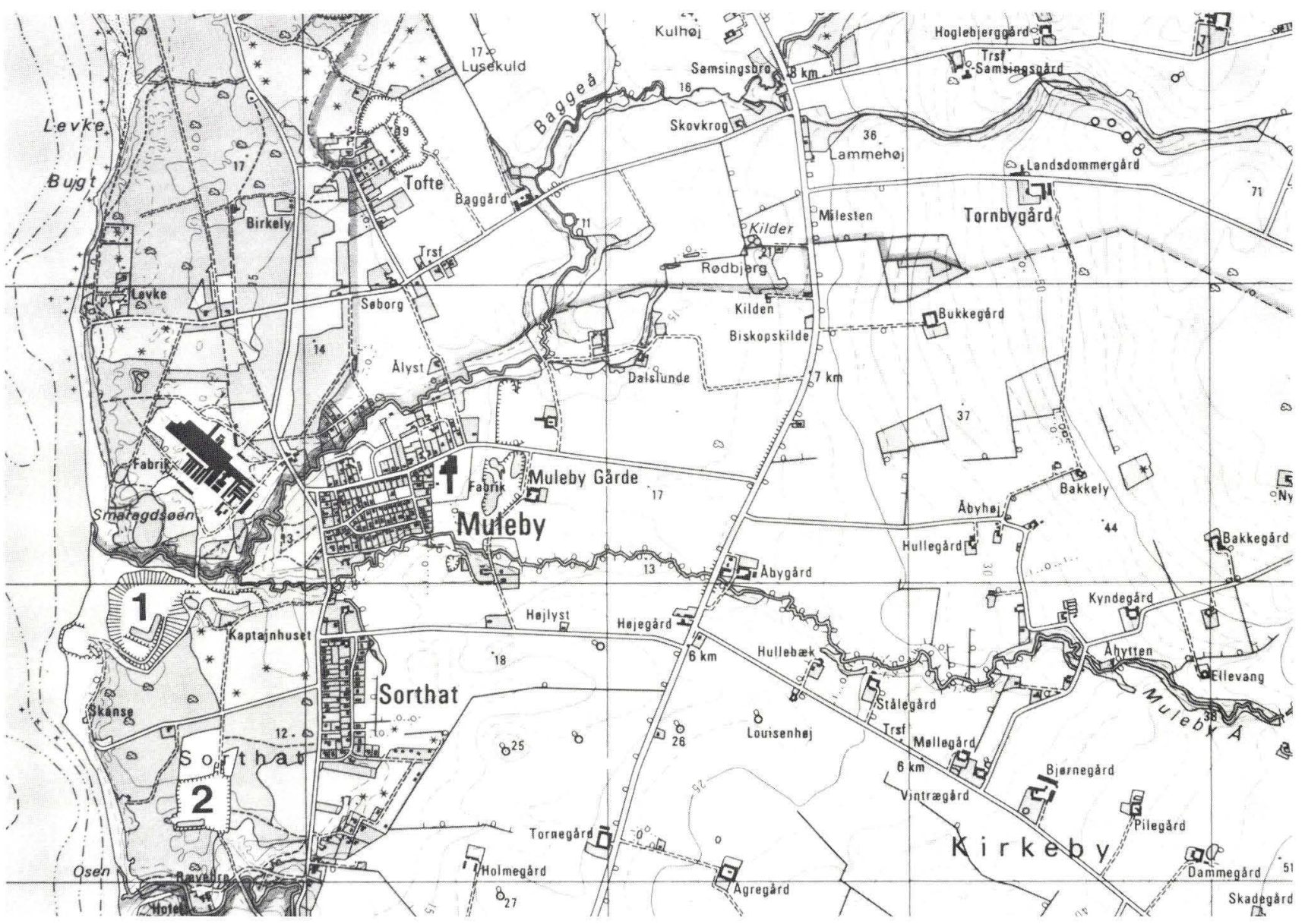

Fig. 20. Topographic map of the area around the Baga clay pits, west coast of Bornholm (see fig. 3). 1 Hasle Klinkerfabrik clay pit, type locality of the Bagå Formation, 2 reference locality of the Bagå Formation. Section of map sheet 1812 IV SV Hasle in the scale 1:25000. Reproduced with the permission A400/76 of the Geodetic Institute. 

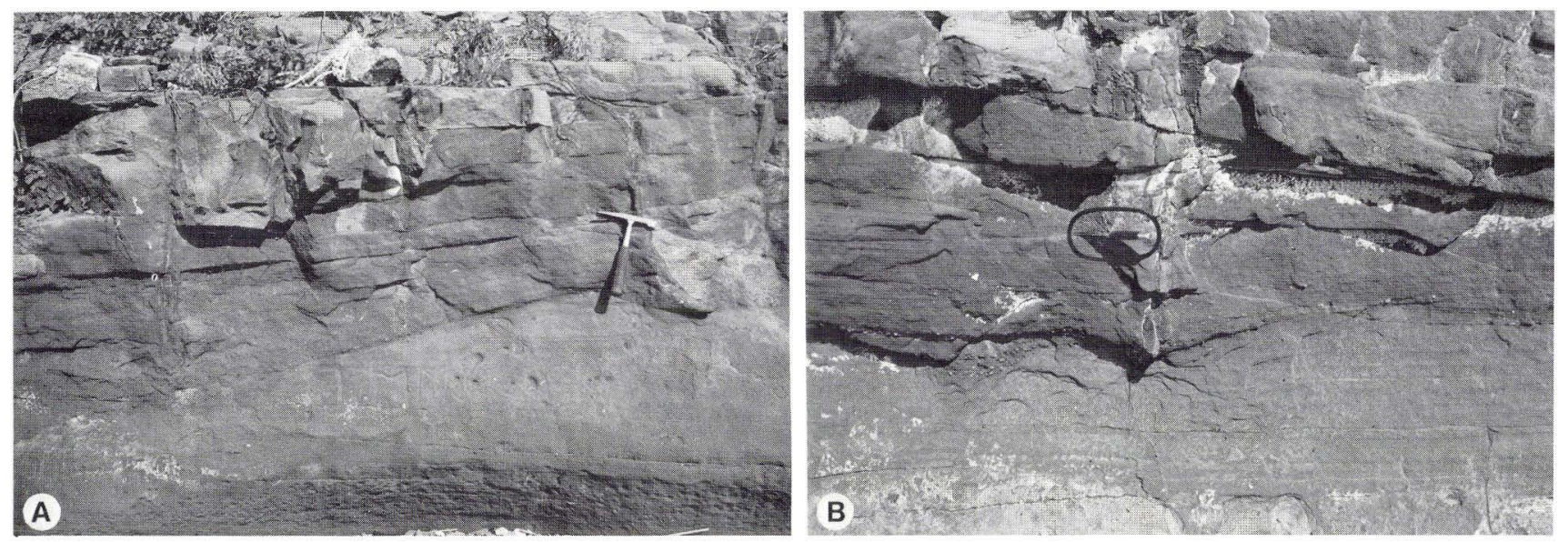

Fig. 21. A \& B. Low-angle cross-bedding in the sandstones of the Hasle Formation. Pebble lags overlie erosional surfaces, immediately south of Hasle harbour. Knife in center of $\mathrm{b}$ for scale. Position indicated by 1 in fig. 19.

characteristic yellowish brown colour. The sandstone is horizontally laminated or low-angle trough crossbedded and generally well sorted, but in places thin gravelly laminae occur (Fig. 21).

Interbedded with the sandstone are thin erosive beds of poorly sorted gravel with abundant shell fragments. Occasionally $10-50 \mathrm{~cm}$ thick beds of greenish grey to brown clay with clay-ironstone occurs. They are more frequent in the lower part of the formation.

\section{Boundaries}

The lower boundary is taken where the largely unconsolidated heterolithic sand and clay with carbonaceous detritus of the Rønne Formation change to indurated limonitic brownish sandstone or thick clay beds containing marine fossils. The upper boundary is placed at the change to largely unconsolidated interbedded sand, clay and coal seams of the Bagå Formation.

\section{Distribution}

The formation occurs immediately south of Hasle, and in a continuous band from Sorthat to Korsodde (Fig. 2) (Malling, 1914).

\section{Geological age}

Lower Pliensbachian, zones of Uptonia jamesoni to Prodactylioceras davoei. A rich fauna has been collected from the formation (Forchhammer, 1837; Lundgren, 1879; Malling \& Grönwall, 1909; Malling, 1911, 1914, 1920; Höhne, 1933) containing more than 60 species of brachiopods, bivalves, and gastropods; some belemnites, fish and plesiosaur remains have been recorded in addition to approximately ten ammonite species.

\section{Bagå Formation}

\section{New formation}

\section{History}

The coal-bearing clay of the Bagå Formation has been known since the start of coal mining around 1800 and excavation for clay around 1890 (Forchhammer, 1837; Jespersen, 1866; Bartholin, 1892, 1894; Møller, 1902, 1903; Gry 1947, 1951, 1960, 1969, 1977b; Graff-Petersen, 1961; Graff-Petersen \& Bondam, 1963; Rolle et al. 1979). The sequence included in the formation is known under the local names Levka, Sorthat and Bagå beds which cannot be precisely correlated due to complicated tectonics and rapid lateral and vertical facies changes. According to Malling (1920) and Gry (1969) the Levka and Sorthat beds are roughly contemporaneous while part of the Bagå beds may be slightly younger. Coalbearing beds at Korsodde and Onsbæk and a conglomerate bearing sequence at Boderne (Gry, 1969) are also included in the formation.

\section{Name}

After the stream Bagå. The name is spelt Baggeå on the newest topographic maps, but Baga in the geological literature and on older maps. The latter version is used here as it has been used both as a topographic and as an informal formation name, Bagå series or Bagå beds (Gry, 1960, 1969).

Fig. 22. Type section of the Bagå Formation, Hasle Klinkerfabrik clay pit. Position indicated by 1 in fig. 20 and 1 in fig. 23. Measured by F. Rolle in 1976. 

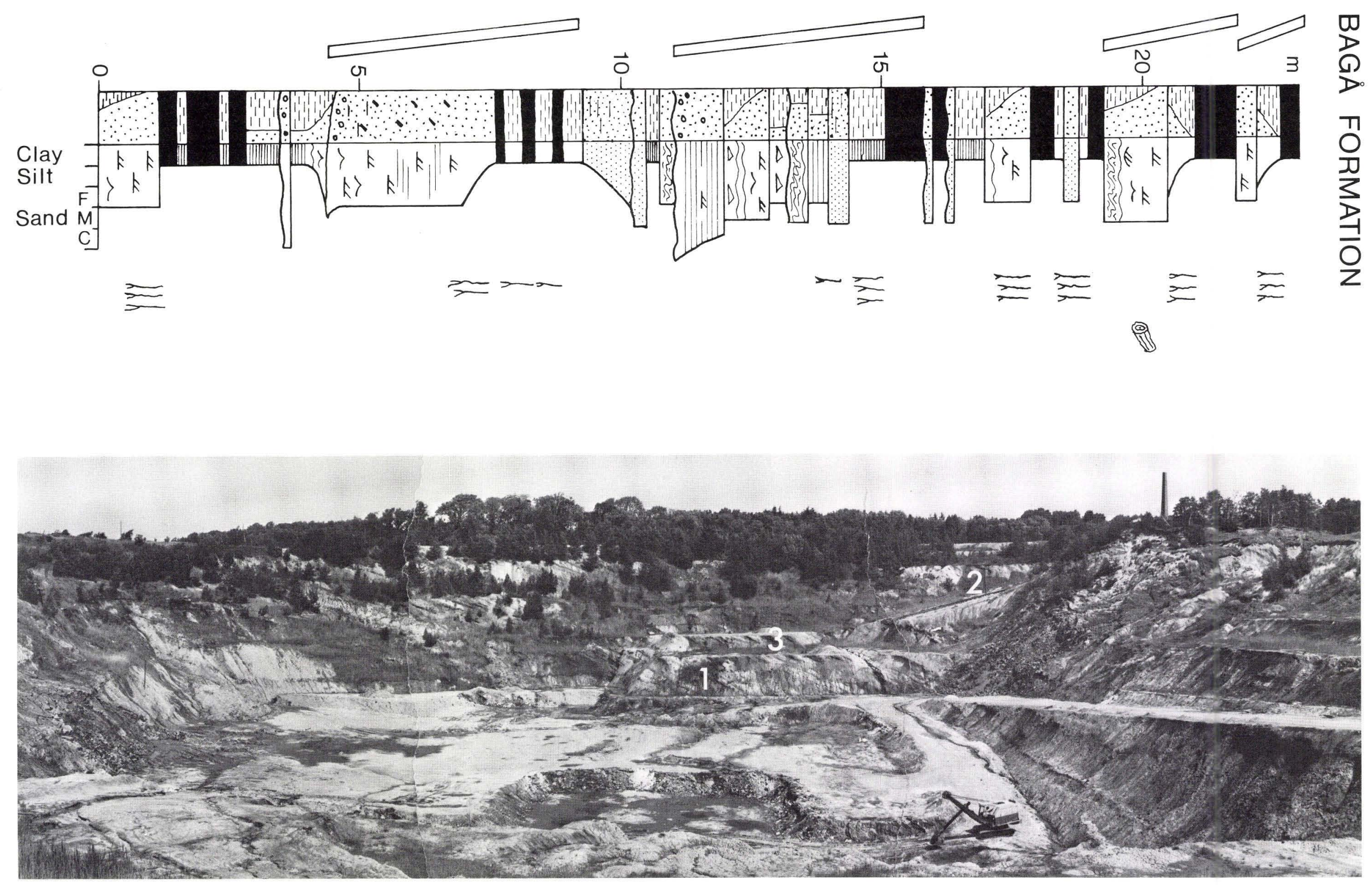

Fig. 23. Panorama of the north wall of the Hasle Klinkerfabrik clay pit showing eastwards dipping sand, clay and coal-beds of the Bagå Formation. 1 indicates the position of the type section. 2 indicates beds with deeply kaolinized granite boulders resedimented from a N-S oriented fault scarp situated a few hundred metres to the east (fig. 25c). 3 indicates position of section of fig. $25 \mathrm{a}$. 


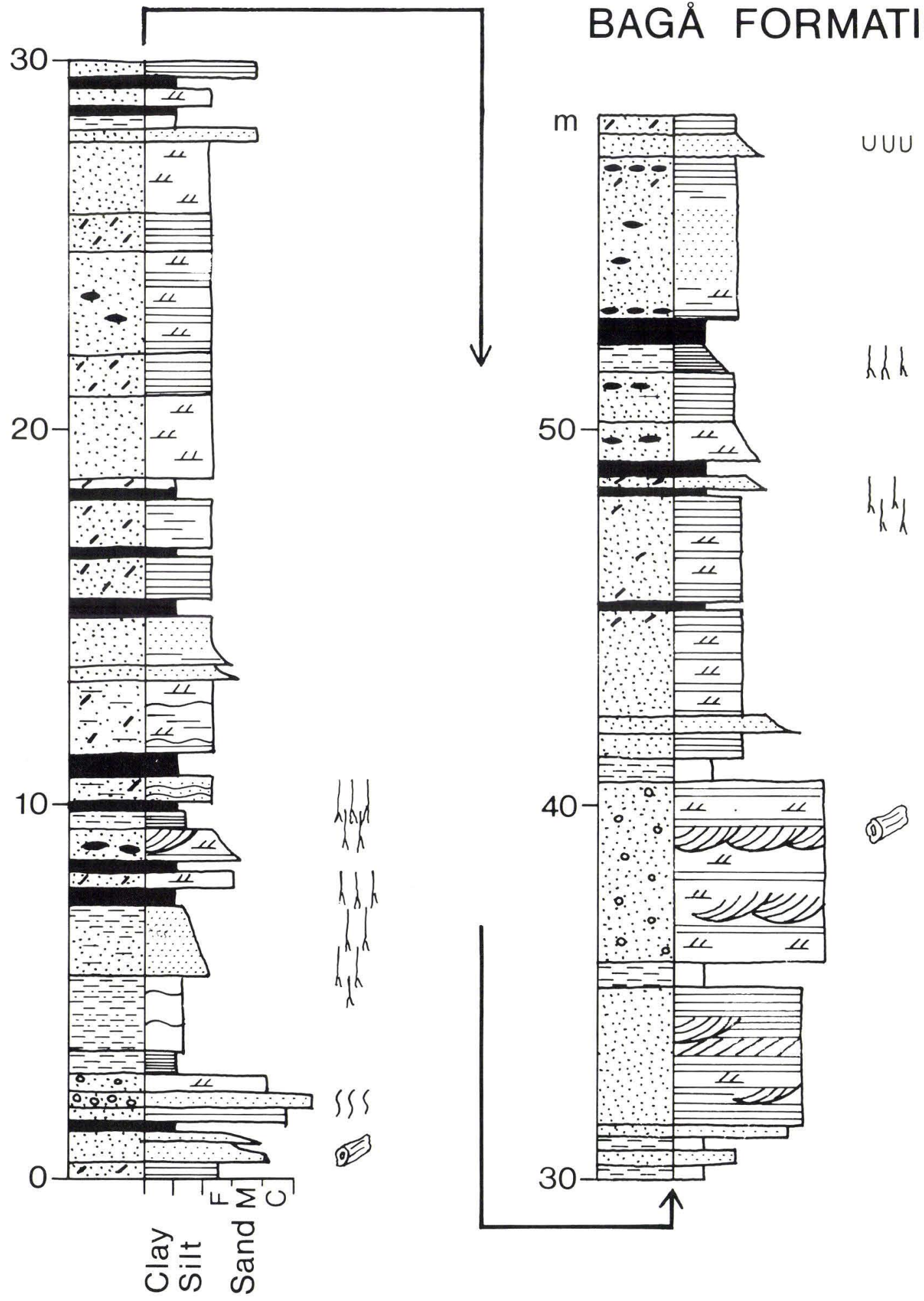

Fig. 24. Reference section of the Baga Formation. Position indicated by 2 in fig. 20. Measured by F. Rolle in 1976.
Type locality

The big Hasle Klinkerfabrik clay pit immediately south of the stream Bagå (Figs. 20, 22, 23).

Reference section

Section in clay pit c. $500 \mathrm{~m} \mathrm{~S}$ of the type locality (Figs. 20, 24).
Thickness

More than $270 \mathrm{~m}$ (Gry, 1960).

\section{Lithology}

The formation consists of coarse and fine-grained cross-laminated sand, heteroliths, clay and coalseams characteristically arranged in fining-upwards 

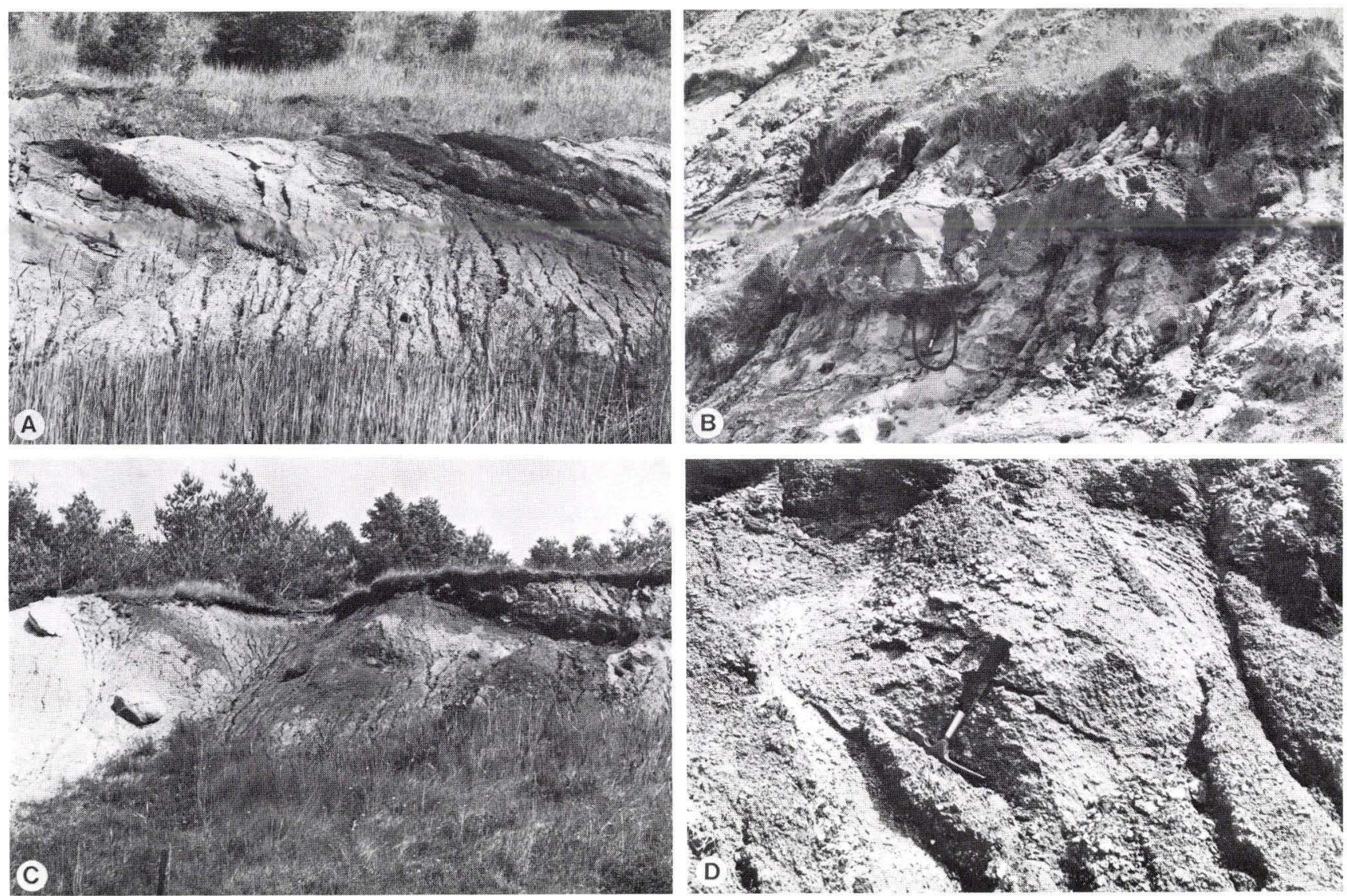

Fig. 25. Lithologic details of the Bagå Formation, type locality (figs 22, 23). A: Eastwards dipping beds of sandstone, clay and coal at 3 in fig. 23. B: Crevasse channel filled with graded pebbly, cross-bedded sandstones with numerous fragments of plants, stems and leaves. Hammer for scale. C: Kaolinized granite boulders resedimented from fault-scarp to the east. Position indicated by 2 in fig. 23. D: Deeply kaolinized granite boulder seen to the extreme right in c.

cycles (Fig. 22). The topmost beds at the type locality include extremely poorly sorted conglomerates containing boulders of kaolinized granite more than $1 \mathrm{~m}$ in diameter (Fig. 25).

\section{Boundaries}

The Bagå Formation overlies the ferruginous marine sandstones of the Hasle Formation. At Boderne (Fig. 2) it unconformably overlies Silurian shales. The upper boundary is not known as the formation forms the top unit within its distributional area.

\section{Distribution}

The formation is restricted to the Rønne - Hasle block, and a small outlier at Boderne (Fig. 2).

\section{Geological age}

The formation can be roughly dated to the Middle Jurassic, Bajocian-Bathonian Stages (Florin, 1958; Gry, 1969).

\section{Nyker Group}

New group

\section{Name}

After the town of Nyker, north-western part of Bornholm (Fig. 3).

\section{Thickness}

Maximum thickness about 250 m (Gry, 1960).

\section{Lithology}

The group commences with the Rabekke Formation, which includes fluvial sandstone, sand and clay (Homandshald Member) followed by supratidal-intertidal swamp clay, lignite and sand (Skyttegård Member). Then follows the Robbedale Formation with fine-grained intertidal flat, coastal lagoon and beach sand (Østerborg Member) and medium and coarse-grained subtidal, intertidal, barrier and sandwave sand (Langbjerg Member). At the top follows 
the Jydegård Formation which consists of back-barrier, washover fan and lagoon deposits comprising clay, clay-ironstone, silt, sand and sandstone (Rødbjerg and Tornhøj Members).

\section{Boundaries}

The group rests on Lower Jurassic sediments of the Bornholm Group in the Arnager-Sose block, oversteps partly kaolinized Palaeozoic sandstone and shale in the Bøsthøj block, and Precambrian crystalline basement rocks and kaolin in the Knudsker and Nyker blocks. It is unconformably overlain by the Albian-Cenomanian Arnager Greensand Formation (see Kennedy, Hancock \& Christensen, 1980).

\section{Distribution}

The group or part of the group occurs in six fault blocks: The Holsterhus, Bøsthøj, Arnager-Sose, Knudsker, Nyker and Salene blocks (Fig. 2). It is possibly also present in the subsurface offshore areas around Bornholm (see Andersen et al, 1975; Kögler \& Larsen, 1979; Kumpas, 1980).

\section{Geological age}

The group is mainly of Lower Cretaceous, Berriasian - Valanginian Age, but the lower part of the sequence may still be of latest Jurassic, Tithonian Age. The group is not younger than lowermost Albian (Ravn, 1925; Kennedy et al., 1980).

\section{Subdivision}

The group is subdivided into the Rabekke (base), Robbedale and Jydegård (top) Formations.

\section{Rabekke Formation}

Gry $(1956,1960)$

\section{History}

Sediments and fossils of the formation have been described by many authors (e.g. Jespersen, 1865; Rørdam, 1890; Bartholin, 1910; Grönwall and Milthers, 1916; Andersen, 1944; Graff-Petersen and Bondam, 1963). The formation was established by Gry (1960) and corresponds to "the basal sequence" ("bundserien") and "the lower clay sequence", ("nedre lerserie") of Gry (1956).

\section{Name}

From the Rabekke clay pit (Rabekkeværket) in the Knudsker block (Fig. 26).

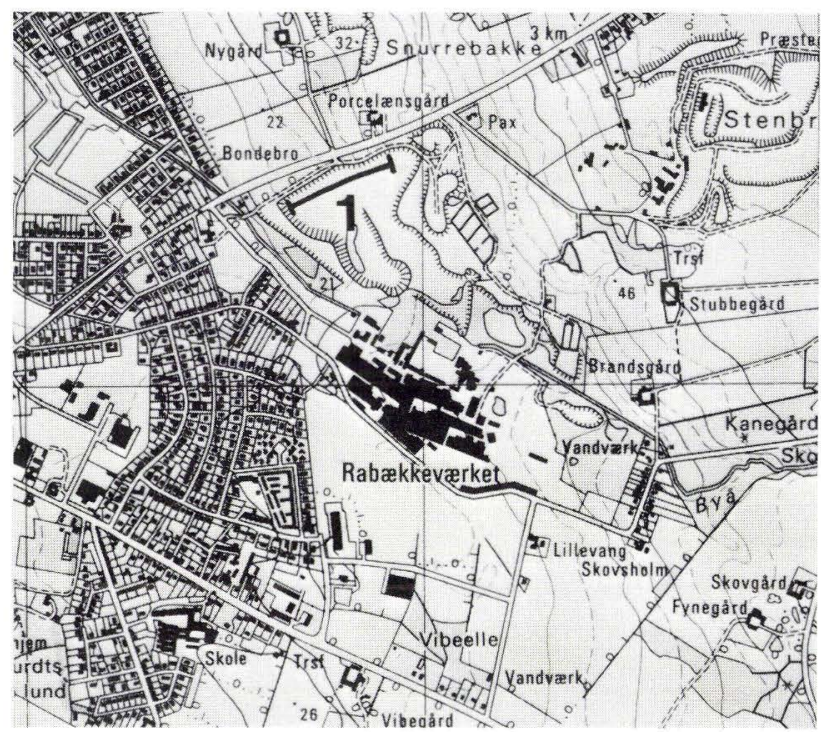

Fig. 26. Topographic map of the area immediately east of Rønne (see fig. 3). 1 Rabekke clay pit. Section of map sheet 1812 III NV Rønne in the scale 1:25000. Reproduced with the permission A400/76 of the Geodetic Institute.

\section{Type locality}

The coast at Arnager Bugt (Figs. 27, 28).

\section{Reference localities}

Rabekke clay pit and Skyttegård clay pit (Figs. 26, 27).

\section{Thickness}

Gry (1956, 1960) gives the following thicknesses: Nyker block 45-105 m, Knudsker block 60-90 m, Arnager-Sose block at least $49 \mathrm{~m}$ and Bøsthøj block at least $13 \mathrm{~m}$.

\section{Lithology}

Medium to coarse-grained ferruginous sandstone, kaolinitic poorly sorted pebbly sand, and dark grey and variegated clay and silt are the dominating sediments. Plant material and small sideritic concretions are abundant.

\section{Boundaries}

The lower boundary is only exposed in the Rabekke clay pit, where clay with sand and pebble horizons rests on kaolin or kaolinized basement rocks with a gradual contact (Graff-Petersen and Bondam, 1963). In other areas the formation oversteps onto Lower Jurassic and Palaeozoic sediments or Precambrian kaolinized basement, and the lower boundary is known from borings only (Gry, 1956). 


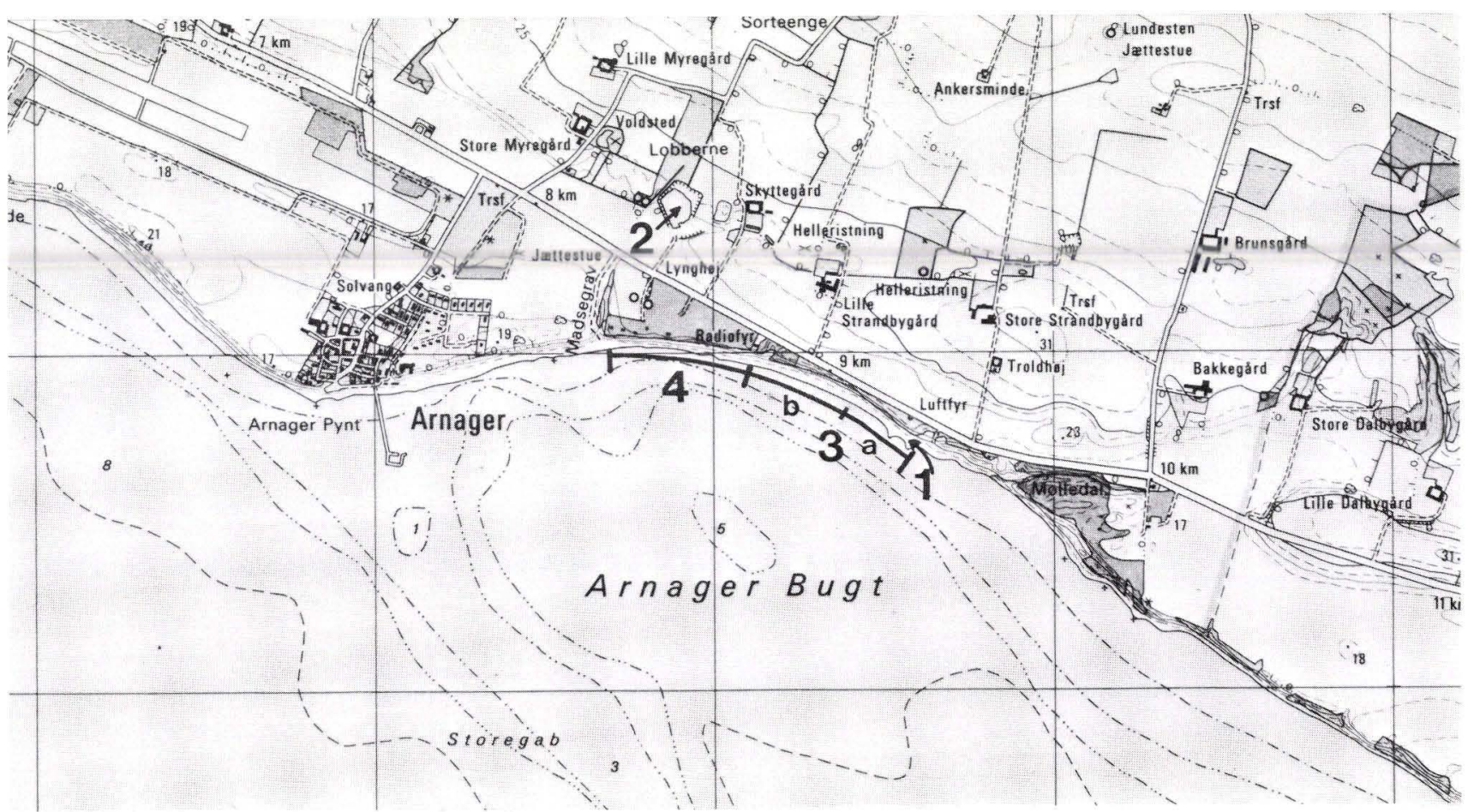

Fig. 27. Topographic map of the south coast of Bornholm around Arnager Bugt (see fig. 3 ). 1 Homandshald, 2 Skyttegård clay pit, 3 type locality of the Rabekke Formation, 3a type locality of the Homandshald Member, 3b type locality of the Skyttegård Member, 4 reference locality of the Robbedale Formation. Section of map sheet 1812 III NV Rønne in the scale 1:25000. Reproduced with the permission A $400 / 76$ of the Geodetic Institute.

The upper boundary is exposed at Arnager Bugt, where black and grey silty and gravelly clay is succeeded by grey brown silty fine-grained sand of the Robbedale Formation.

\section{Distribution}

The formation is known from all the blocks where the group is found (Fig. 2).

\section{Geological age}

In the Arnager-Sose block the formation rest on Lower Jurassic sediments of the Galgeløkke Member, Rønne Formation and thus cannot be older. The upper part of the formation has yielded ostracods which according to Christensen (1963, 1966, 1968, 1974) are contemporaneous with forms from the German Oberer Münder Mergel and Serpulit. These units are today dated as Lower-Upper? Berriasian (Casey, 1963; Dörhöfer and Norris, 1977; Surlyk, 1980). The lower part is probably also of Berriasian Age, but a Tithonian Age cannot be excluded.

\section{Subdivision}

The Rabekke Formation is subdivided into a lower Homandshald Member and an upper Skyttegård Member.

\section{Homandshald Member}

New member

\section{History}

The sediments of the Homandshald Member have been described from the area at Homandshald in Arnager Bugt by various authors (e.g. Jespersen, 1865; Grönwall and Milthers, 1916; Höhne, 1933; Andersen, 1944). The member corresponds to "the basal sequence" ("bundserien") of Gry (1956), Rabekke Formation, sand, of Gry (1960), or "basal" member of Christensen (1963).

\section{Name}

After Homandshald, an old and widely used name for the type locality approximately $900 \mathrm{~m}$ east of Madsegrav in Arnager Bugt (Jespersen, 1865) (Fig. 27).

\section{Type locality}

Arnager Bugt (Fig. 27).

\section{Thickness}

In the Nyker block the thickness increases from a few metres in the northeast to approximately $25 \mathrm{~m}$ towards the southwest; in the Knudsker block it thick- 


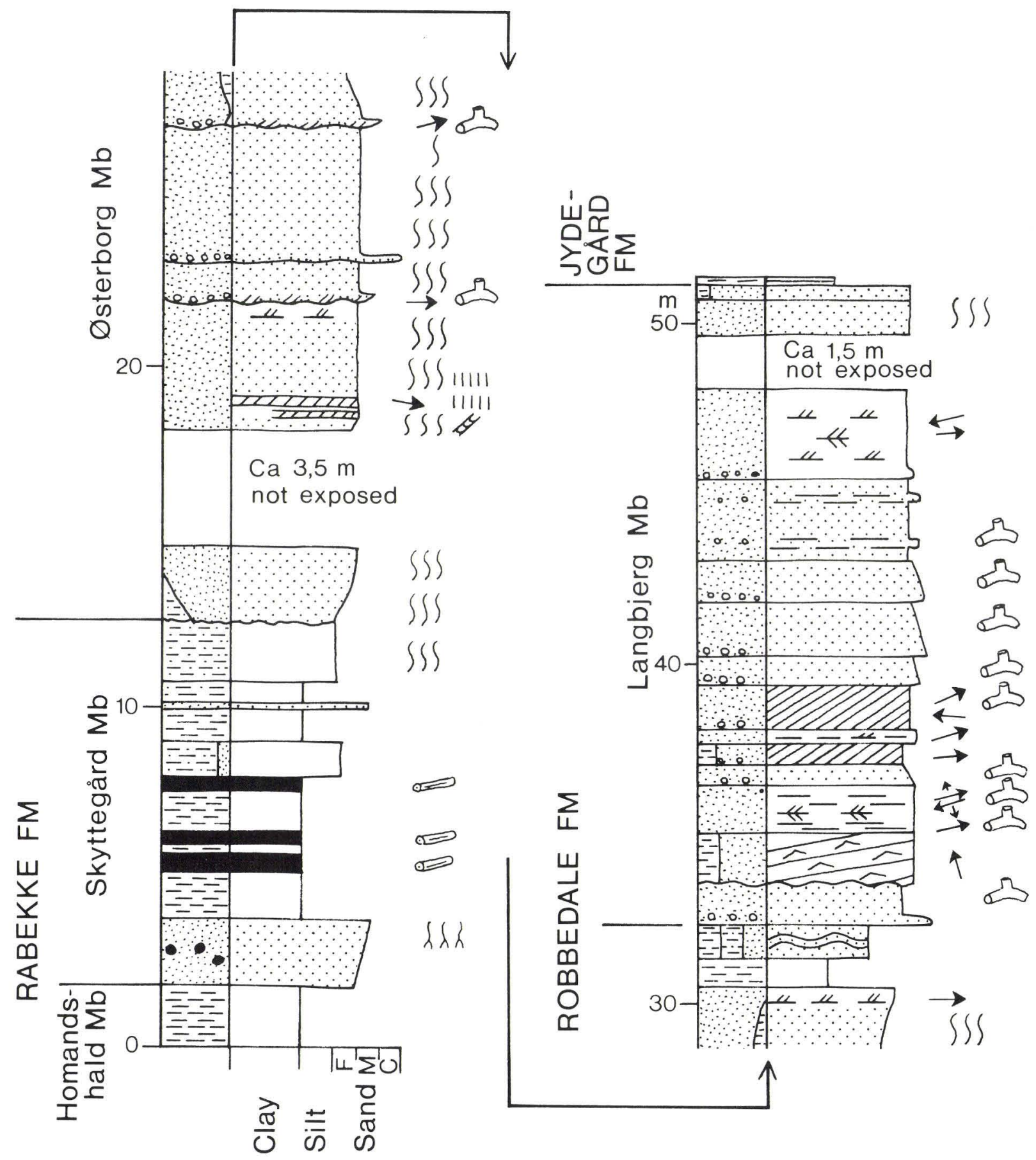

Fig. 28. Type section of the Rabekke Formation and the Skyttegård Member, and reference section of the Robbedale Formation, Arnager Bugt. Position indicated by 3, 3b and 4 on fig. 27. Measured by P. Gravesen in 1976.

ens from 4-6 $\mathrm{m}$ at the Rabekke clay pit (Grönwall and Milthers, 1916) to at least $30 \mathrm{~m}$ towards the southwest, and in the Arnager-Sose block the thickness is $20-30 \mathrm{~m}$ at Arnager Bugt (Gry, 1956; Gravesen, 1977 a).

\section{Lithology}

Cross-bedded or structureless medium to coarsegrained ferruginous sandstone with sideritic concre- tions and thin pebble beds. Cross-bedded and horizontally laminated poorly sorted sand and pebbles with kaolin is abundant and may occur in small channels with clay clasts (Fig. 29a, b). Sandy clay with pebbles, plant material and rootlets are found in the upper part of the member. Small sideritic concretions are characteristic of the member (Gry, 1956). Light cross-bedded sandstones exposed adjacent to the Risebæk Member clays between Risebæk and Sose 

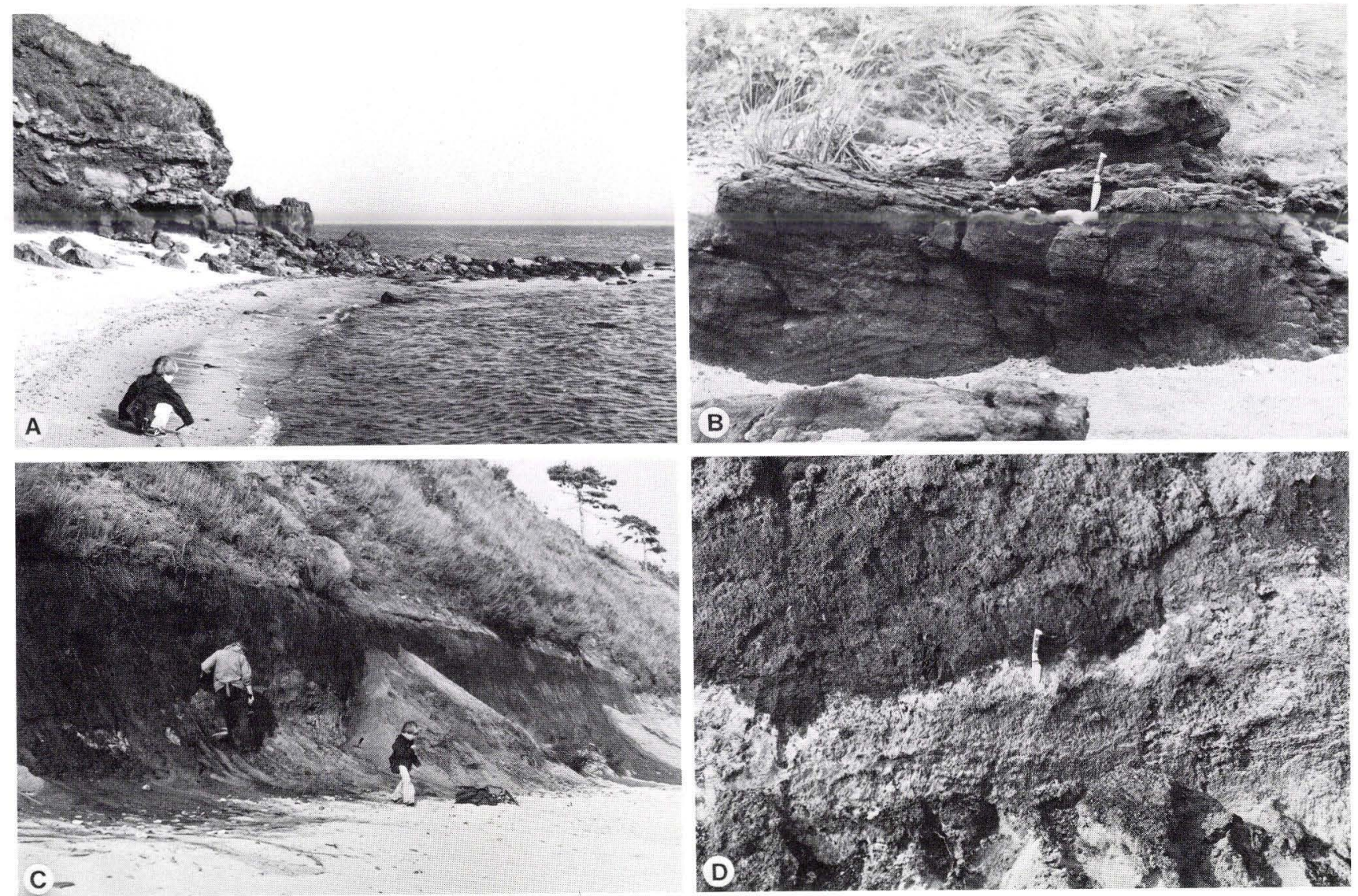

Fig. 29. Details of the Rabekke Formation. A: Type locality of the Homandshald Member. Low cliff in coarse-grained pebbly sandstones with clay clasts and sphaerosiderites. Homandshald, south coast of Bornholm. Position indicated by 1 on fig. 27. B: Trough cross-bedded coarse-grained pebbly sandstone of the Homandshald Member at the type locality. C: Dark clay with gravel, pyrite rods, and rootlets from the middle part of the Skyttegård Member, Arnager Bugt. Position indicated by 3b on fig. 27. D: Details of fig. c showing irregular contact formed by podsolisation, between light clay with gravel and hard yellowish concretions, and black clay with gravel, pyrite nodules and rootlets.

Bugt, especially on the coast below Julegård (Fig. 6) may belong to this member.

\section{Boundaries}

The member rests on Precambrian basement rocks, kaolin, Palaeozoic sediments or the Lower Jurassic Galgeløkke Member. The upper boundary is placed at the upper surface of a light grey sandy clay bed with silty kaolinitic fine-grained sand which is overlain by fine to medium-grained non-kaolinitic silty sand with abundant carbonaceous debris of the Skyttegård Member (Fig. 28).

\section{Distribution}

The member occurs in all areas, where the formation is known (Fig. 2).

\section{Geological age}

The member contains no fossils and the age is indirectly determined. The conformably overlying Skyttegård Member is Lower - Upper? Berriasian (Chri- stensen, 1963, 1966, 1968, 1974), and the Homandshald Member is most likely Tithonian? Lower Berriasian.

\section{Skyttegård Member}

\section{New member}

\section{History}

The clay of this member has been known as "Pottemagerler" and has been excavated for use in potteries in various pits at Rævehus ("Potterekulerne") and at Skyttegård (Forchhammer, 1837; Jespersen, 1865; Grönwall, 1899; Grönwall and Milthers, 1916; Gry, 1956, 1960). In the Rabekke clay pit the clay has been investigated in detail (Rørdam, 1890; Höhne, 1933; Graff-Petersen and Bondam, 1963). From Holsterhus Bartholin (1910) described the fossil flora.

The member corresponds to "the lower clay se- 
quence" ("nedre lerserie") of Gry (1956) and "upper member" of Christensen (1963).

\section{Name}

From Skyttegård clay pit (Fig. 27).

Type locality

Arnager Bugt (Figs. 27, 28).

\section{Reference locality}

Skyttegård clay pit (Fig. 27).

\section{Thickness}

In the Nyker block 40-80 m; in the Knudsker block c. $60 \mathrm{~m}$; in the Arnager-Sose block c. $44 \mathrm{~m}$; and in the Bøsthøj block c. 13 m (Gry, 1956).

\section{Lithology}

Multi-coloured often sandy clay with silt and sand beds. The colour is mainly dark grey, but also black, green, brown, light brown and occasionally variegated green, black, yellow brown. The clay is generally structureless and has a very high content of plant detritus with beds of horizontally deposited lignite. Rootlets and red yellow weathering horizons occur (Gry, 1956) and fine-grained siderite and pyrite are common (Fig. 29c, d).

\section{Boundaries}

The member overlies the Homandshald Member with a gradual contact (see p. 31), and the upper boundary coincides with the upper boundary of the Rabekke Formation (see p. 29).

\section{Distribution}

The same as the Rabekke Formation.

\section{Geological age}

The member contains ostracods (Christensen, 1963, 1966, 1968, 1974) and megaspores (Gry, 1969) of Early and possibly Late Berriasian Age.

\section{Robbedale Formation}

Gry (1956, 1960)

\section{History}

The sediments of the formation have been known as the "the Robbedale gravel and floursand" ("Robbedale grus og melsand") and have been described by many authors (e.g. Jespersen, 1865, 1869; Johnstrup, 1889; Grönwall, 1899; Grönwall and Milthers, 1916; Höhne, 1933; Andersen, 1944).
The formation was defined by Gry (1960) and includes "the Robbedale gravel and fine sand" and "Wormsand" ("Robbedale grus og finere sand" og "Ormesand") of Gry (1956).

\section{Name}

From the Robbedale area in the Arnager-Sose block where the formation is well exposed in several sand pits (Fig. 7).

Type locality

A/S Carl Nielsen's sand pit (Figs. 7, 30).

Reference locality

Arnager Bugt (Figs. 27, 28).

\section{Thickness}

In the Nyker block 8-20 m; in the Knudsker block c. $18 \mathrm{~m}$; in the Bøsthøj block c. $10-30 \mathrm{~m}$; and in the Arnager-Sose block c. 40 m (Gry, 1956; Gravesen, 1977a).

\section{Lithology}

Fine, medium or coarse-grained, faintly horizontally laminated, cross-bedded, or structureless quartz sand with a few pebbles. Ophiomorpha, Skolithos and other trace fossils are common and total bioturbation characterizes parts of the formation. Rootlets and plant detritus occur in several horizons.

\section{Boundaries}

The lower boundary is to the Rabekke Formation (see p. 29). The upper boundary to the Jydegård Formation is exposed in the A/S Carl Nielsen sand pit (Fig. 30), and it is placed at the first thin clay bed just below a sequence with several beds of clayironstone.

\section{Distribution}

The formation is found in the Nyker, Knudsker, Arnager-Sose and Bøsthøj blocks (Fig. 2).

\section{Geological age}

At present no age diagnostic fossils have been found in the formation, and the age can only be determined indirectly. The underlying Rabekke Formation is mainly of Early Berriasian Age. The lower part of the overlying Jydegård Formation contains ostracods comtemporaneous with forms from the German Wealden 3 (Christensen, 1963, 1974). This unit is today dated as Late Berriasian to Valanginian and possibly younger (Surlyk, 1980). The Robbedale Formation is thus probably of Late Berriasian Age. 


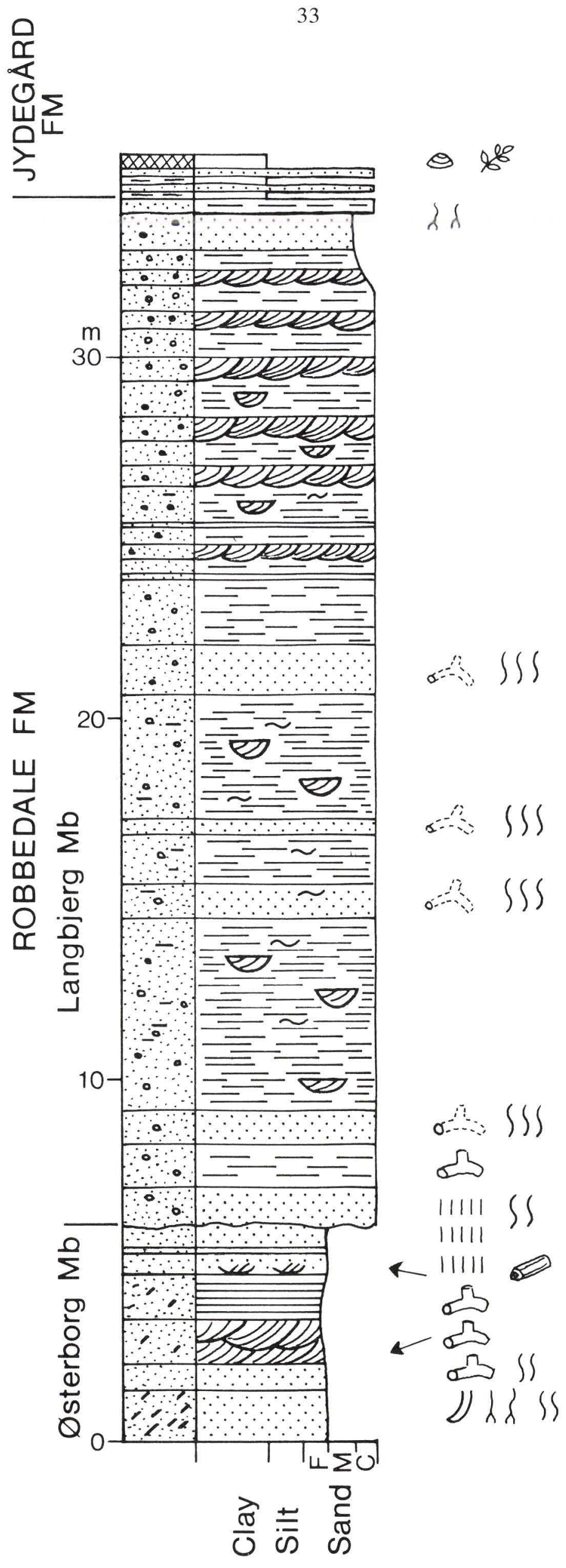

Fig. 30. Type section of the Robbedale Formation at A/S Carl Nielsen's sand pit. Position indicated by 2 on fig. 7. Measured by P. Gravesen in 1977. 


\section{Subdivision}

The Robbedale Formation is subdivided into a lower Østerborg Member and an upper Langbjerg Member.

\section{Østerborg Member}

New member

\section{History}

The member has been described as "the floursand" ("Melsand") (e.g. Grönwall and Milthers, 1916) and corresponds to the "Wormsand" ("Ormesandet") of Gry (1956). Allen (1967) analysed heavy minerals from the sand of the member.

\section{Name}

From Østerborg sand pit (Fig. 7).
Type locality

Østerborg sand pit (Fig. 7); a section is published by Gry (1968, Fig. 4).

\section{Reference localities}

A/S Carl Nielsen's sand pit (Fig. 7) and Arnager Bugt (Fig. 27).

\section{Thickness}

In the Arnager-Sose block at least $18 \mathrm{~m}$; in the Knudsker block c. $7 \mathrm{~m}$; in the Nyker block 0-8 m; and in the Bøsthøj block 4-10 m (Gravesen, 1977a; Gravesen, Bækgaard \& Villumsen, 1980).

\section{Lithology}

Mainly fine-grained quartz sand with subordinate beds of coarse-grained sand and pebbles. The sand can be very silty and thin silt and clay beds are present. Plant detritus and rootlets are common in scat-
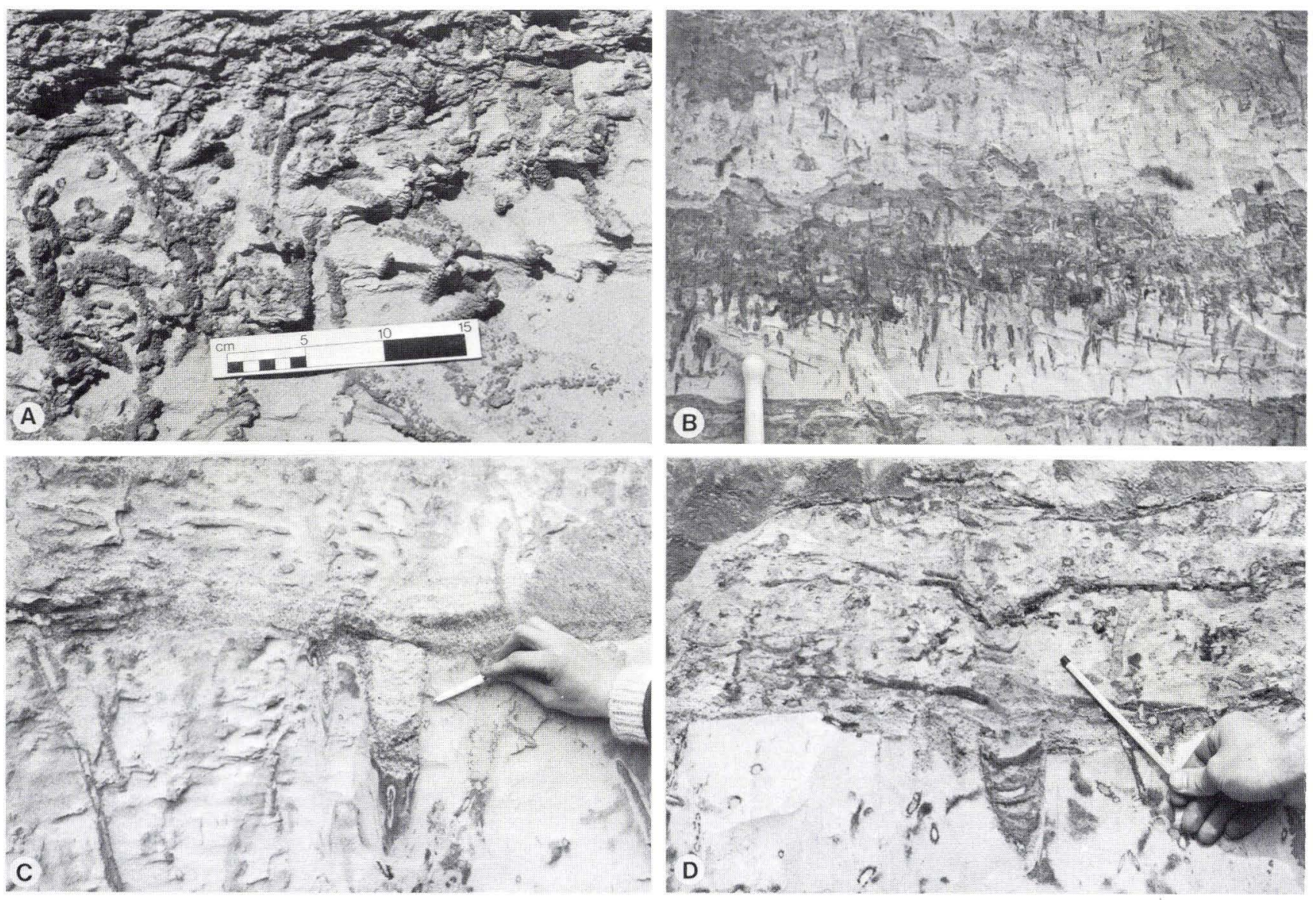

Fig. 31. Lithological details of the Østerborg Member, Robbedale Formation. A: Dense population of Ophiomorpha nodosa in small-scale cross-laminated fine-grained sand. At the top completely bioturbated sand and clay, A/S Carl Nielsen's sand pit (2 on fig. 7). B: Low-angle cross-bedded sand with vertically orientated Ophiomorpha nodosa. Length of showel handle about $15 \mathrm{~cm}$. C: Fine-grained sand with subvertical Ophiomorpha nodosa and collapse structures over Ophiomorpha burrows, overlain by coarse gravelly sand layer of storm origin. The coarse sand fills the collapse structure (left of pencil). D: Fine-grained sand with scattered Ophiomorpha nodosa overlain by bioturbated coarse-grained gravelly sand of storm origin. Large escape burrows with collapse structure in the center. B, c, and d from Arnager Bugt, east of Madsegrav (fig. 27). 
tered beds. Galleries of Ophiomorpha and Skolithos are characteristic, and the sand is often totally bioturbated (Fig. 31). Cross-bedded, horizontally laminated or structureless sand and small channels are also found.

\section{Boundaries}

The lower boundary coincides with that of the formation (p. 32). The upper boundary to the Langbjerg Member is sharp on all localities. In the Robbedale area fine-grained sand is overlain by coarse-grained sand (Fig. 30) and at Arnager Bugt heterolithic deposits are succeeded by pebbly sand (Fig. 28).

\section{Distribution}

The member is known from the same blocks as the formation (Fig. 2), although it may be absent from parts of the Nyker block.

\section{Geological age}

Probably Upper Berriasian (Surlyk, 1980).

\section{Langbjerg Member}

\section{New member}

\section{History}

The name "Robbedale gravel" ("Robbedale grus") has been used for sediments of this member (e.g. Jespersen, 1865; Gry, 1956; Christensen, 1963) (see p. 32).

\section{Name}

After the hill Langbjerg in the Robbedale area. The name is not indicated on the recent geodetic maps.

\section{Type locality}

A/S Carl Nielsen's sand pit (Figs. 7, 30).

\section{Reference localities}

Østerborg sand pit and Arnager bugt (Figs. 7, 27).

\section{Thickness}

In the Nyker block 0-20 m; in the Knudsker block c. $10 \mathrm{~m}$; in the Arnager-Sose block $0-28 \mathrm{~m}$; and in the Bøsthøj block c. 6-22 m (Gry, 1956; Gravesen, 1977a; Gravesen et al., 1980).

\section{Lithology}

Medium to coarse-grained quartz sand with few pebbles is the dominant sediment. The sand can be faintly horizontally laminated, cross-bedded, structureless or slightly graded and is often bioturbated

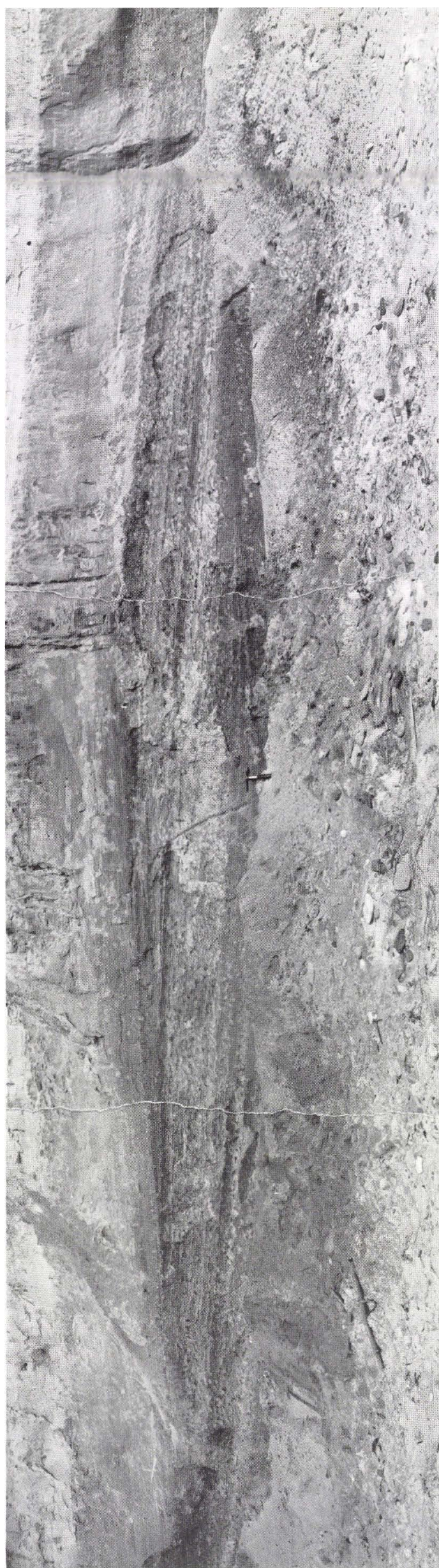



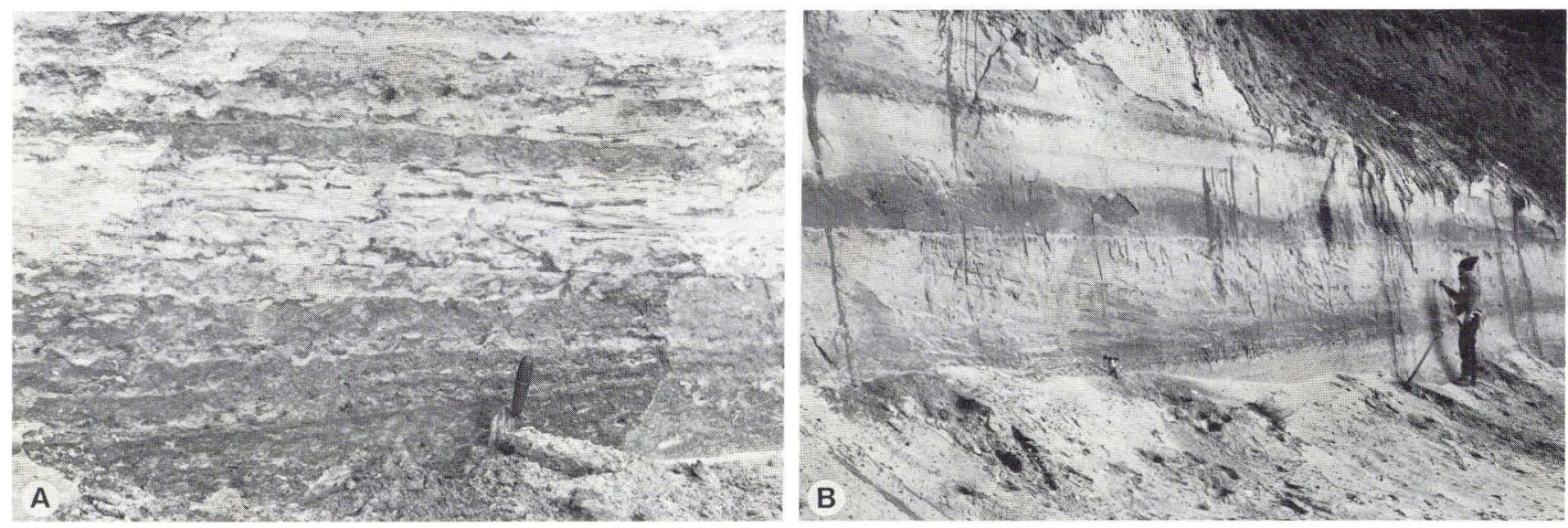

Fig. 33. Lithological details of the Langbjerg Member at Arnager Bugt. A: Detail of the low-angle point-bar cross-bedding on fig. 32. The bedding plane passing through the handle of the mason trowel was originally in a horizontal position while the higher beds dipped to the right. Note the muddy and highly bioturbated nature of the cross-strata. B: Thick beds of medium-grained sand. The bed at the level of the figure's head is large-scale cross-bedded, while the overlying beds are structureless and graded. Ophiomorpha nodosa extend from the upper surface of each bed. Corresponds approximately to $34-42 \mathrm{~m}$ part of the section on fig. 28 .

with Ophiomorpha as an abundant trace fossil (Figs. 32, 33). Skolithos and other trace fossils also occur. Thin clay beds are rare, while clay flasers are abundant.

\section{Boundaries}

The lower boundary is described under the Østerborg Member (p. 35), and the upper boundary under the Robbedale Formation (p. 32).

\section{Distribution}

Same as the Robbedale Formation (Fig. 2), but possibly absent in parts of the Nyker and the ArnagerSose blocks (Gravesen et al., 1980).

\section{Geological age}

Probably Upper Berriasian (Surlyk, 1980).

\section{Jydegård Formation}

Gry $(1956,1960)$

\section{History}

The sediments from this formation have been known from clay pits (Rønne Lervarefabriks gamle grav, Jydegård lergrav), borings and a few other localities (Grönwall, 1899; Grönwall and Milthers, 1916; Malling, 1920; Andersen, 1944; Gry, 1956). The fossil flora and fauna of the formation has briefly been treated by e.g. Möller (1902), Malling (1920), Grönwall and Milthers (1916) and Gry (1956, 1968). Gry (1960) erected the formation by formalising "the upper clay sequence" ("øvre lerserie") of Gry (1956).

\section{Name}

From the Jydegård clay pit (Fig. 34).

\section{Type locality}

Jydegård clay pit (Figs. 34, 36).

\section{Thickness}

In the Nyker block 90-110 m; in the Knudsker block at least $4 \mathrm{~m}$; and in the Arnager-Sose block from a few metres to c. 60 m (Gry, 1956; Gravesen, 1977a).

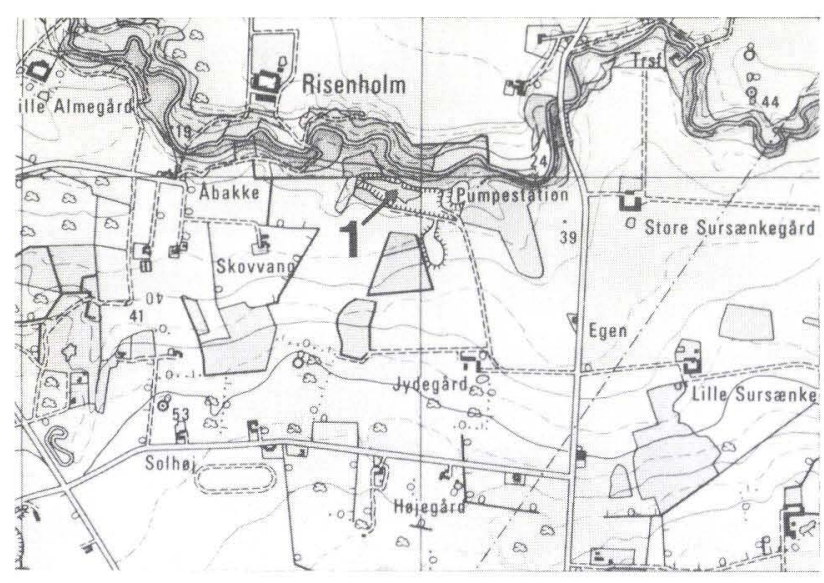

Fig. 34. Topographic map of the area at Jydegård (see fig. 3). The position of the type locality of the Jydegård Formation shown on fig. 36 is indicated with 1 . Section of map sheet 1812 III NV Rønne in the scale 1:25000. Reproduced with the permission A400/76 of the Geodetic Institute. 


\section{Lithology}

The alternating beds of fine, medium or coarsegrained cross-bedded, structureless or horizontally laminated sand, sandstone, silt, clay and clay-ironstone are characteristic. Wave-ripple laminated sand and clay occur in the lower part. Load structures are abundant, bioturbation and trace fossils occur, and part of the formation contains oolitic chamosite. Fresh and brackish water bivalves and gastropods are found in several horizons.

\section{Boundaries}

The lower boundary is described under the Robbedale Formation (p. 32). The upper boundary is placed where the formation is overlain unconformably by the glauconitic sand and phosphoritic conglomerate of the Albian-Cenomanian Arnager Greensand Formation (Ravn, 1925; Kennedy et al., 1980).

\section{Distribution}

The formation occurs in the Nyker, Knudsker and Arnager-Sose blocks (Fig. 2).

\section{Geological age}

Uppermost Berriasian to Valanginian (see p. 32; Surlyk, 1980). The upper part of the formation may be younger, but is older than Albian (Ravn, 1925; Kennedy et al., 1980).

\section{Subdivision}

The Jydegård Formation is subdivided into the Tornhøj and the Rødbjerg Members.

\section{Tornhøj Member}

\section{New member}

\section{Name}

From the hill Tornhøj in the northwestern part of the Robbedale area (Fig. 7).

\section{Type section}

DGU boring file No. $246.305,1.0-48.3$ m.b.s. (Fig. 38). The boring is used as type section, since the known exposures in the Robbedale area have a thickness of c. 10-12 m only (Gry, 1968; Gravesen, 1977b; Noe-Nygaard and Surlyk, in prep.).

Fig. 35. Reference section of the Jydegård Formation. Reference section of the Tornhøj Member. Position indicated with 2 on fig. 7. Measured by N. Noe-Nygaard and F. Surlyk in 1980 .

3 D.G.U. serie B, nr. 7

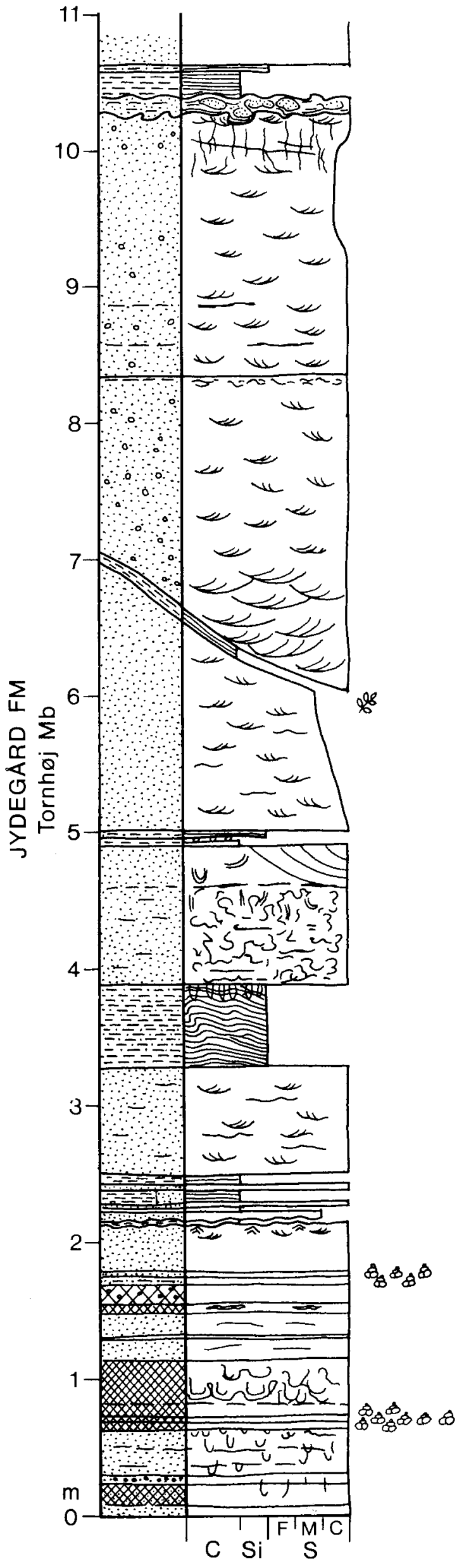



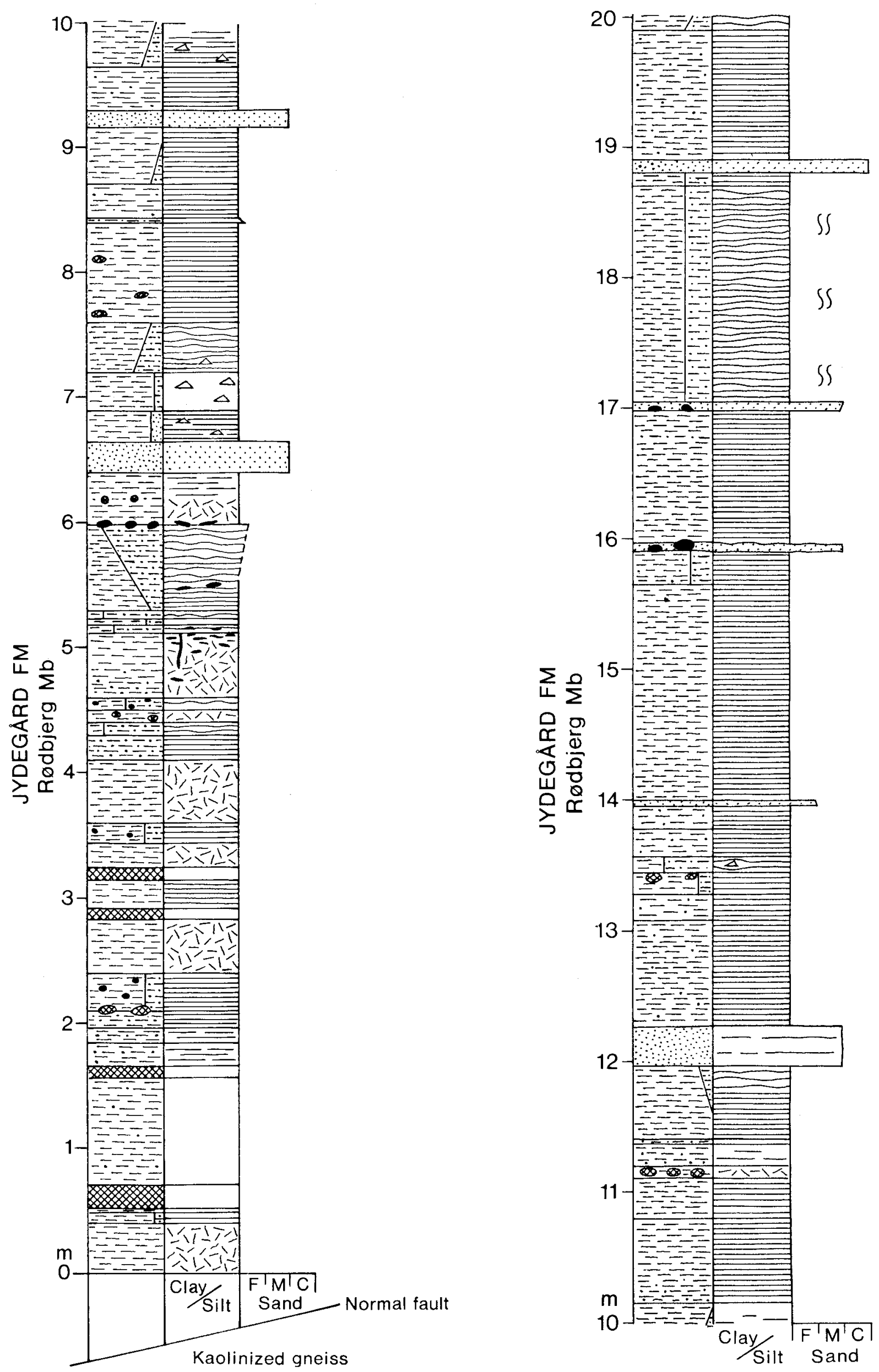

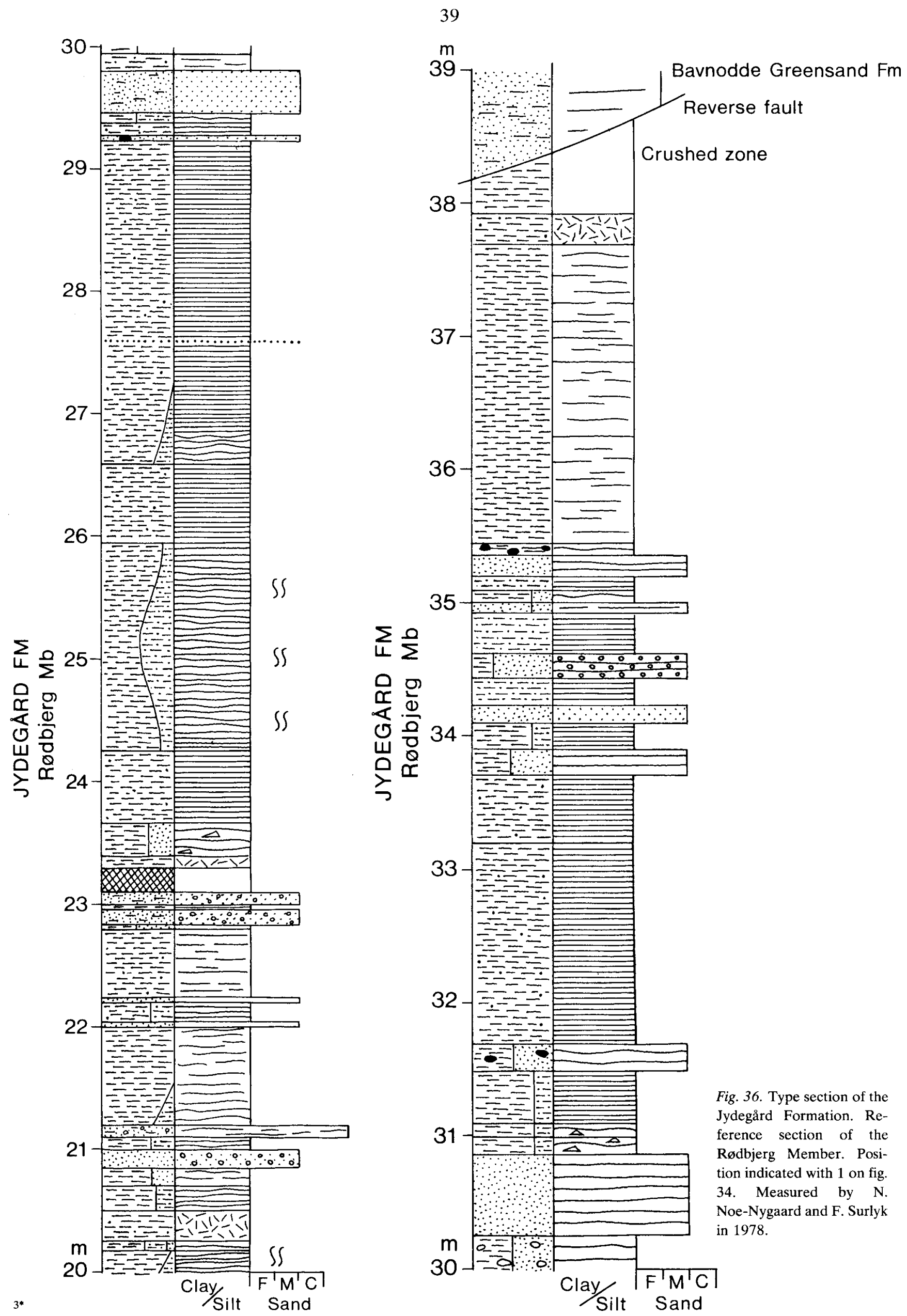


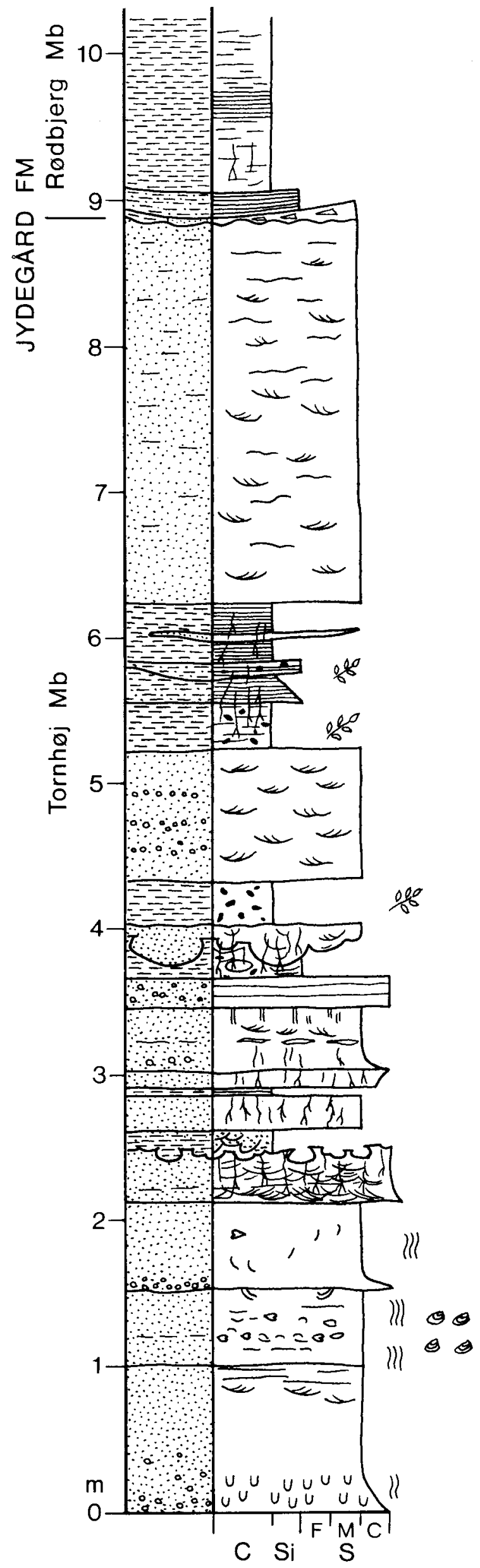

Reference sections

Sections in the Skrædderbakke sand pit (Figs. 10, 37) and the A/S Carl Nielsen's sand pit (Figs. 7, 35) (Noe-Nygaard and Surlyk, in prep.), and DGU file No. 246.492, 4.3-54.3 m.b.s. (Fig. 38).

\section{Thickness}

The member is only present in the Arnager-Sose block with a thickness increasing from a few metres in the southwest to c. $60 \mathrm{~m}$ in the central Robbedale area (Gry, 1956; Gravesen, 1977a).

\section{Lithology}

Rapid alternation of relatively thin beds of different grain-size is characteristic of this member, which comprises the following types of sediment (Figs. 35-41). Fine, medium and coarse-grained cross-bedded, faintly horizontally laminated, structureless or bioturbated sand, structureless or horizontally laminated silt, clay and clay-ironstone. Individual clay beds in several cases change laterally from clay to clay-ironstone and normally wedge out over rather short distances (Noe-Nygaard and Surlyk, in prep.). Load structures are abundant. The bed geometry is sheet like in the lower part, while sand or clay filled channels are characteristic of the upper part. The member contains concentrations of monospecific assemblages of gastropods, bivalves, and conchostracans. Vertebrate remains and plant fossils occur scattered (Malling, 1920; Gry, 1956, 1968; Gravesen, 1977a; Noe-Nygaard and Surlyk, in prep.).

\section{Boundaries}

The Tornhøj and the Rødbjerg Members are probably interfingering, but the boundary is not known. The boundary to the underlying Robbedale Formation is exposed in the A/S Carl Nielsen's sand pit (Fig. 40a, b), and is described under this formation (p. 32). The upper boundary coincides with that of the Jydegård Formation.

\section{Distribution}

The member is only known from the Arnager-Sose block (Fig. 2).

\section{Geological age}

No age-diagnostic fossils have yet been found in the Tornhøj Member. It is assumed to be of late Late Berriasian-Valanginian or younger Age.

Fig. 37. Section through the Tornhøj Member, Jydegård Formation at Skrædderbakke. Position indicated with 2 in fig. 10. Measured in 1980 by N. Noe-Nygaard and F. Surlyk. 


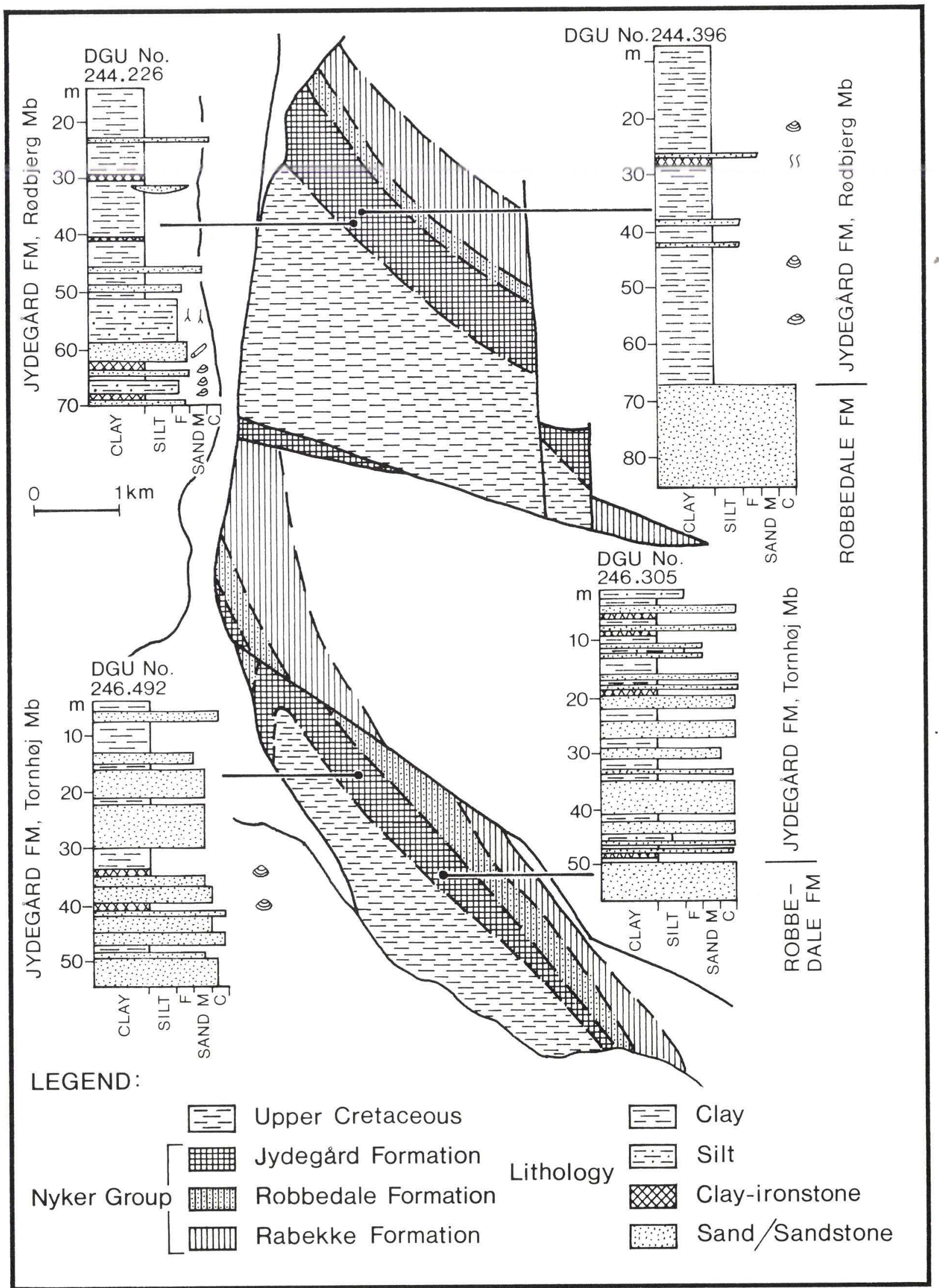

Fig. 38. Sections of the Jydegård Formation from four borings (well data file, D.G.U.). 244.226 shows a marginal facies of the fine-grained Rødbjerg Member. 244.396: Type section of the Rødbjerg Member, shows the boundary between the sands of the Robbedale Formation and the clays of the Rødbjerg Member, Jydegård Formation. 246.305 is type section and 246.492 reference section for the Tornhøj Member. 


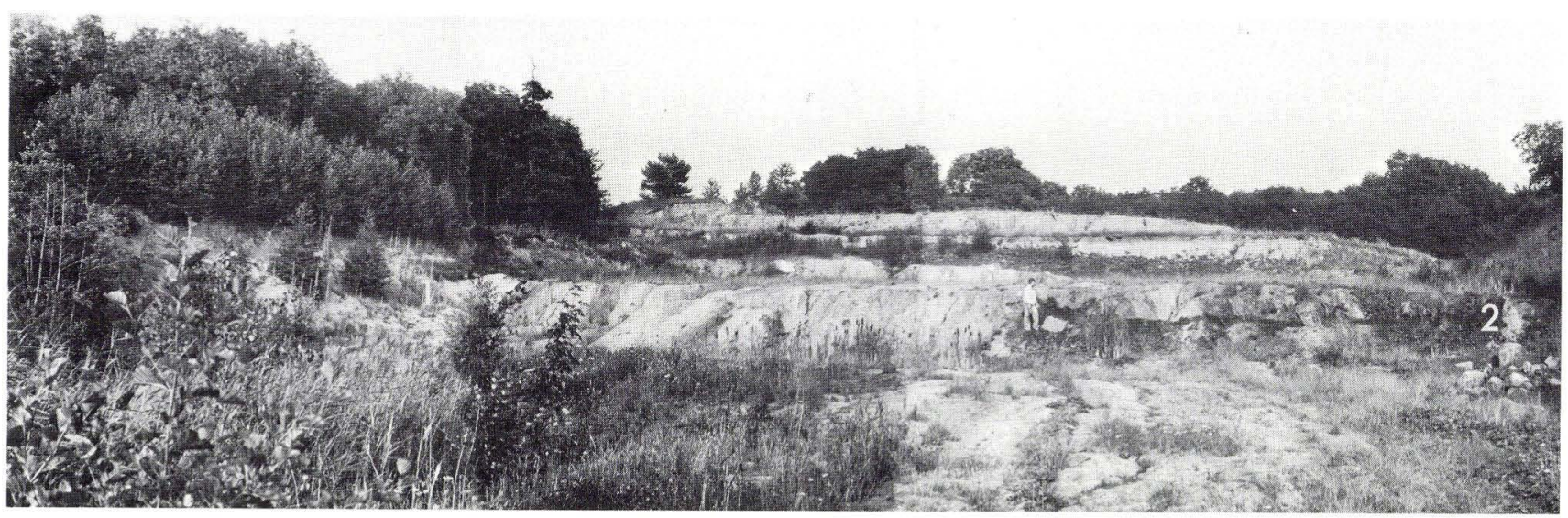

Fig. 39. Type locality of the Jydegård Formation (position see fig. 34). To the left Santonian Bavnodde Greensand Formation, in the middle vertical strata of the Jydegård Formation (Rødbjerg Member), and to the right kaolinized Precambrian gneiss. 1 and 2 indicate the position of the reverse and normal faults respectively, which delimit the thin sliver of the Jydegård Formation. The section on fig. 36 was measured in the narrow escavated trench visible as a dark horizontal line to the right in the figure.

\section{Rødbjerg Member}

\section{New member}

\section{Name}

From the hill Rødbjerg in the central Nyker block.

\section{Type section}

The section is found in the boring DGU file No. 244.396, 12,3-67,0 m.b.s. (Fig. 38). The boring is used as type section since the exposure in the Jydegård clay pit is in a tectonically isolated fault sliver (Gry, 1956, 1960; Noe-Nygaard and Surlyk, in prep.).

\section{Reference sections}

DGU file No. 244.226, 14-70 m.b.s. (Fig. 38) and Jydegård clay pit (Noe-Nygaard and Surlyk, in prep.) (Fig. 36).

\section{Thickness}

The member seems only to occur in the Nyker block, where the thickness probably is 90-110 m (Gry, 1956), and in the Knudsker block where it is very thin.

\section{Lithology}

The member consists mainly of relatively finegrained sediments. Laminated sticky olive grey clay with silt and sand streaks is the characteristic facies with subordinate thin sandstone, siltstone and clayironstone beds. Rather thick beds of silt and finegrained very silty sand often occur in the lower part of the member (Gravesen et al., 1980).

Oolitic chamosite, pyrite and mica are characteris- tic constituents, and occasionally septarian concretions with trace fossils are seen. Foraminifers, ostracods, gastropods, fish teeth, megaspores and plants occur in thin beds (Malling, 1920; Gry, 1956).

\section{Boundaries}

The two members of the Jydegård Formation are assumed to be interfingering, but the boundary between them is not known from outcrops or borings. The boundary of the Rødbjerg Member to the underlying Robbedale Formation is placed in the DGU boring No. 244.396, where coarse-grained sand is succeeded by sticky clay with sand lenses and concretions at $67.0 \mathrm{~m}$ below surface (Fig. 38). The exact nature of the boundary is not known. The upper boundary is known from a few borings, where the sticky clay is overlain by the Arnager Greensand Formation.

\section{Distribution}

The member is known from the Nyker block, and it is probably also present in the Knudsker block (Fig. 2).

\section{Geological age}

Uppermost Berriasian-Valanginian or perhaps younger (Surlyk, 1980), but older than Albian (Ravn, 1925; Kennedy et al., 1980).

\section{Tectonic and sedimentary evolution}

Bertelsen (1980) and Michelsen (1978) have broadly outlined the Triassic and Jurassic basinal evolution of 

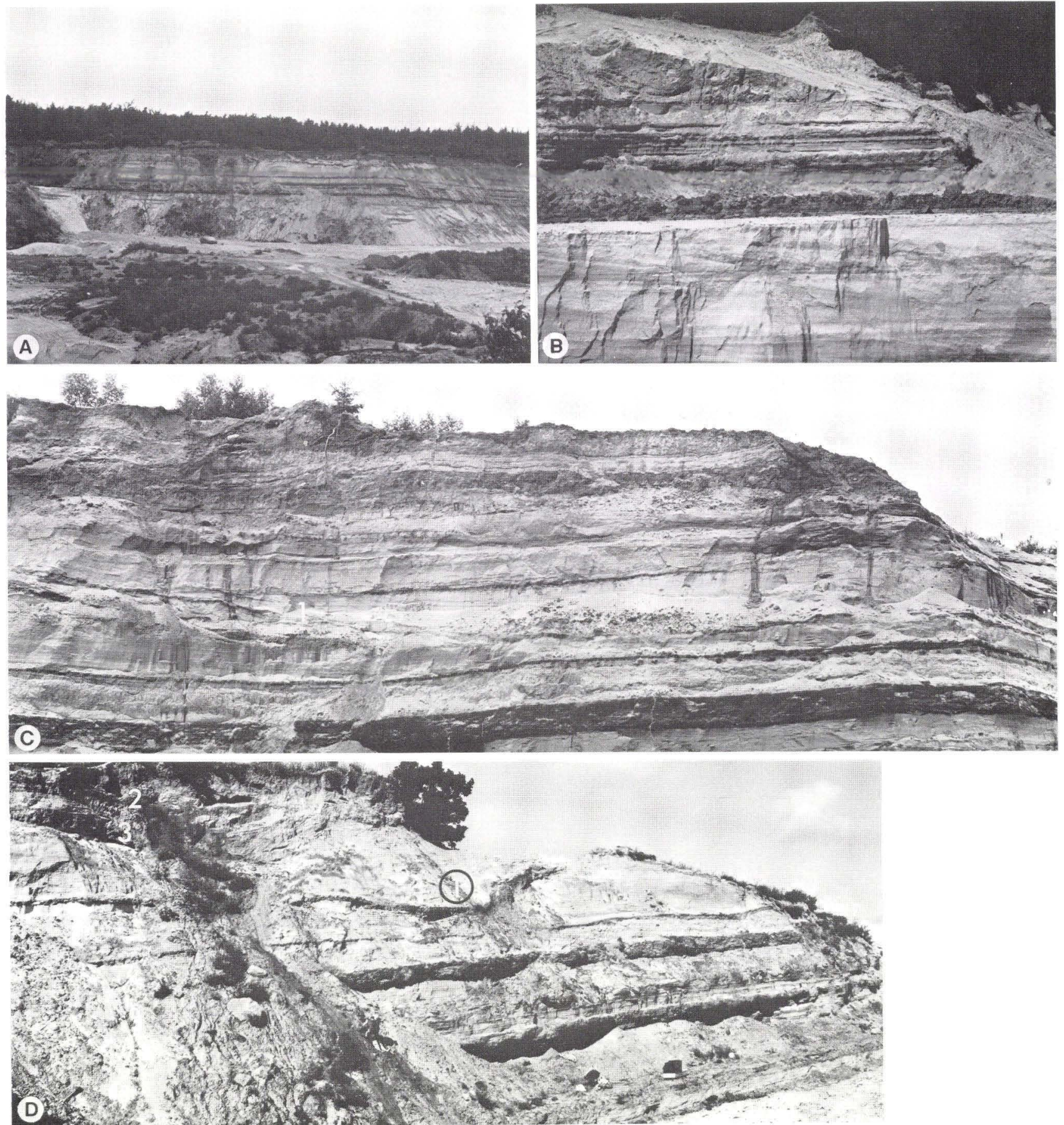

Fig. 40. The boundary strata of the Robbedale and the Jydegård Formations. All from A/S Carl Nielsen's sand pit (2 in fig. 7). A: View towards the SW. The light sands in the lower half of the section belong to the Robbedale Formation (Langbjerg Member), whereas the alternating light sands and dark clays in the upper half belong to the Jydegård Formation (Tornhøj Member). B: Telephoto shot of the boundary between the Robbedale Formation below and the Jydegård Formation above, taken immediately to the left (west) of the profile on a. The boundary is placed at the base of the first dark band, which is the clay-ironstone at the base of the section on fig. 35. C: Upper part of the Tornhøj Member as exposed on a and b. The wall is at a right angle to the section on $\mathrm{b}$. The dark clay band at the base, which is $0.6 \mathrm{~m}$ thick, is shown between 4 and $5 \mathrm{~m}$ on the section on fig. 35. At 1, a sand bed displaying low-angle point-bar accretion surfaces (epsilon cross-bedding) dipping towards the right. D: Same wall as on a, at a later stage of quarrying. Location of section in fig. 35 . The dark clay bed halfway up the section is the same as the one at the base on c. At 1 , a sand filled channel with mud draped floor is cutting down into the lower sand body. At 2 and 3 are seen the left banks of two mud plugged channels cutting into one another. 

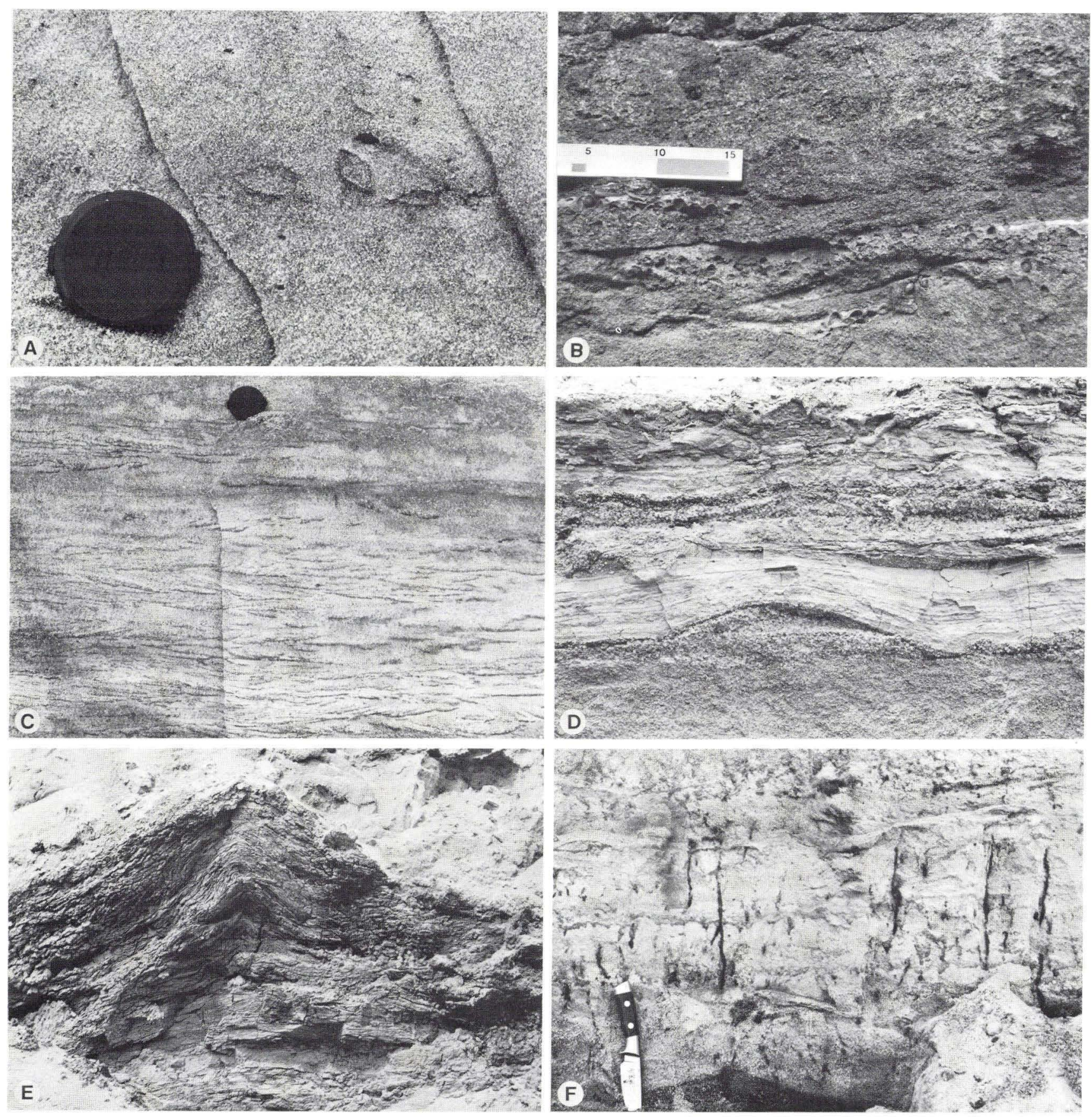

Fig. 41. Details of the Jydegård Formation, Tornhøj Member. A: Ghosts of bivalve shells, probably Neomiodon in medium-grained sand, from the $1.2 \mathrm{~m}$ level in the section on fig. 37. B: Rust impregnated coarse-grained sandstone with low-angle cross-bedding and numerous shells of the fresh-water gastropod Viviparus, from a level corresponding to $3 \mathrm{~m}$ in the section on fig. 35 . C: Small-scale cross-lamination with carbonaceous drapes, from the $6.5 \mathrm{~m}$ level in the section on fig. 35. D: Isolated wave ripple draped by clay, from the level at $3.2 \mathrm{~m}$ in the section on fig. 35. Lenght of ripple $12 \mathrm{~cm}$. E: Slumpfold in $0.6 \mathrm{~m}$ clay bed accentuated by loading, from $4.25-4.9 \mathrm{~m}$ level in the section on fig. 35. F: Rootlets in sandy levée at the top of channel sequence, $11 \mathrm{~m}$ level in section on fig. 35.

the Danish area. The Triassic of Bornholm cannot be easily fitted into this picture due to poor biostratigraphic control and limited exposures. The situation is different for the Jurassic and good possibilities for the study of Lower and Middle Jurassic facies are afforded in Bornholm. However, the Upper Jurassic is absent from the area. In contrast Lower Cretace- ous sediments are well exposed and have received considerable attention.

\section{Triassic continental rift sedimentation}

The Triassic of Bornholm is represented by the Late Ladinian-Carnian Risebæk Member, which can be 
conveniently placed in the Kågeröd Formation. The latter unit forms a characteristic sequence of dominantly coarse-grained red-beds along the FennoScandian Border Zone in Scania.

The relationship between the Kågeröd Formation and the Triassic strata of the Danish underground is not well known. It seems to pass laterally into the fine-grained, anhydritic Oddesund Formation which is characteristic of the central parts of the Danish Subbasin (Bertelsen, 1980). The Kågeröd Formation (termed Kågeröd Beds by Bertelsen, 1980) has been included in the marginal Skagerrak Formation where it according to Bertelsen $(1980$, p. 39,42$)$ should correspond to the upper part of this formation. The mainly continental Risebæk Member was deposited in a very flat and featureless terrain as indicated by scattered occurrences of thin marine horizons of roughly the same lithology as the continental sediments. The sequence is characterized by red and green floodplain clays containing a wide spectrum of caliche nodules varying from rounded or vertically elongate calcitic nodules with pisolithic texture to dense horizontally elongate siliceous nodules. Reworked caliche nodules occur as isolated conglomerate beds or as lags at the base of channel fills. The Risebæk Member probably represents the widest expansion of the Triassic depositional basin and later Triassic Rhaetian strata are not known from Bornholm. The Kågeröd Formation is also in Scania characterized by eastwards overstep onto Palaeozoic and Precambrian rocks. It was deposited as a series of coalescent alluvial fans along the fault bordering the Romele Åsen high (Troedsson, 1942). The Risebak Member mainly corresponds to the upper clayey portion of the Kågeröd Formation and can be interpreted as representing floodplain sediments deposited along the fan fringes. The climate was relatively hot and arid as suggested by the generally oxidized nature of the sediments and the occurrence of caliche. In the more central parts of the depositional basin the red brown, brown and grey anhydritic claystone and siltstone of the correlative Oddesund Formation were deposited in brackish to hypersaline conditions. The environments have been described as periodically flooded sabkhas, ephemeral lakes, and in the centre more permanent salt lakes (Bertelsen, 1980 p. 37).

The basin expansion is interpreted as a result of progressive down-faulting along the Fenno-Scandian Border Zone. According to Troedsson (1942) the deposition of the Kågeröd Formation was also accompanied by tectonic movements as there is a marked angular unconformity to the overlying Rhaetian. Troedsson (1942) suggested that the tectonic phase was compressional resulting in folding, and this concept prevails in much of the literature on the Scanian Mesozoic. There is, however, little doubt that the Mesozoic tectonic activity was mainly of extensional nature resulting in block faulting and tilting. Evidence of strike-slip faulting is, however, known from several localities and local folding due to transpression is probable.

Late Triassic block faulting resulted in non-depositon or erosion of the Rhaetian on Bornholm but sediments of this age are probably preserved in the deep grabens immediately west and south of Bornholm.

\section{Early Jurassic basin expansion and transgression}

The next phase of sedimentation was heralded by basin expansion in the earliest Jurassic accompanied by development of lacustrine conditions as expressed by the Munkerup Member. A lower delta plain was rapidly developed where the cross-bedded sand with channels, coal seams and rootlet beds of the lower Sose Bugt Member were deposited. Continued transgression is shown by the incoming of wave worked beds, marine trace fossils, and tidal flat heteroliths towards the top. The overlying Sinemurian Galgeløkke Member can be interpreted as a generally regressive complex of sandy and muddy tidal flats with a major tidal channel complex with bundle-wise arranged cross-bedded sandstone of dune and sandwave origin topped by a coal-bearing marsh sequence (Sellwood, 1972; Rolle, 1978). This may well be a depositional regression and does not necessarily indicate a regional change of sea-level. Fully marine conditions were finally reached in Early Pliensbachian times during which the fossiliferous beach and foreshore sand of the Hasle Formation was deposited.

The general pattern of sea-level changes thus parallels the evolution of the Danish Subbasin and Scania (Bertelsen, 1978; Michelsen, 1978; Norling, 1972, 1981; Norling, Wikman, Sivhed \& Karis, 1981; Sivhed, 1980). The Hettangian and Sinemurian transgressions are in the basin marked by the incoming of open-marine claystones of the Fjerritslev Formation, which towards the margin pass into the top part of the sandy Gassum Formation, and in Scania by the sandy marginal and deltaic Helsingborg and Döshult Members and the more fine-grained Pankarp Member. Open marine conditions were established throughout the basin in Pliensbachian times with continued deposition of clays of the Fjerritslev Formation and of the more silty and sandy Katslösa Member in Scania. 
This corresponds to deposition of the marine sandy Hasle Formation in Bornholm. The main facies evolution thus seems to reflect the Early Jurassic eustatic sea-level rise, while the development of the local depositional environments and the overstepping nature of the sequence seems to reflect the interplay between eustacy and block-faulting in the FennoScandian Border Zone.

\section{Mid Jurassic tectonism and regression}

The next tectonic phase controlling basin evolution and facies pattern took place at the beginning of the Middle Jurassic, as in the whole North Sea - northern North Atlantic region. This is seen by a major pre-Bajocian hiatus corresponding to the Toarcian and Aalenian Stages, the overstep of Middle Jurassic onto a variety of older strata, the development of a thick Middle Jurassic basal conglomerate at Boderne (Gry, 1969), and the strongly regressive nature of the Bajocian - Bathonian Bagå Formation. The hiatus may reflect erosion following the first phases of mid Jurassic uplift. The tectonic activity continued during the Middle Jurassic as is clearly seen from the occurrence in the Baga Formation of debris flow conglomerates with big boulders of kaolinized gneiss derived from the fault scarp of a granite horst immediately to the east of the depositional basin (Gry, 1960).

The Bagå Formation was laid down in a lower delta plain environment where fining upwards sandclay-coal cycles were deposited in a system of meandering channels, levees and backswamps. Marginal marine conditions with clay deposition were developed in interdistributary bays formed by compaction following channel avulsion. The Baga Formation thus follows the general picture of tectonically controlled Middle Jurassic regression as known from the Eriksdal Formation in Scania (Norling, 1972; Koch, 1979; Rolle et al., 1979), the Haldager Formation in the Dansk Subbasin (Michelsen, 1980), the Brent Formation in the northern North Sea (e.g. Bowen, 1975; Eynon, 1980), and the Pelion Member in East Greenland (Surlyk, 1977a; Surlyk et al., 1973; Surlyk \& Clemmensen, in press).

\section{Early Cretaceous basin expansion}

A third major mid-Mesozoic hiatus then follows on top of the Middle Jurassic as the whole of the Upper Jurassic is absent. This is probably due to erosion in latest Jurassic times during the first phases of the next period of block faulting and basin expansion. The Tithonian? - Valanginian Nyker Group rests with marked unconformity on the older strata and transgresses large areas of deeply kaolinized basement rocks. Isolated outliers of the group suggest that all of Bornholm now for the first time during Mesozoic times became a depositional basin. This corresponds to the generally transgressive nature of the contemporaneous Bream and Vedsted Formations in the Danish Subbasin. The Nyker Group commences with the coarse-grained fluviatile valley-fill sediments of the basal Homandshald Member of the Rabekke Formation, which rapidly passes into lacustrine and swamp sand and clay of the Skyttegård Member. While deposition of the Homandshald Member was mainly continental the Skyttegård Member contains thin marginal marine intercalations. The Skyttegård Member can be correlated with the upper part of the Vitabäck Clays Member in Scania (Christensen, 1968; Norling, 1981). The whole Nyker Group shows a broad regressive-transgressive-regressive pattern, where the Upper? Berriasian Robbedale Formation represents the most marine stage in this evolution. It contains fine-grained sand and clay of beach, tidal flat and lagoonal origin of the Østerborg Member overlain by coarse-grained sand of sandwave and barrier beach origin of the Langbjerg Member (Gravesen, 1977a, b). The Robbedale Formation has close contemporaneous analogues in the Bückeberg Formation of northern Germany (Kemper, 1973), and as far away as in the Raukelv Formation of East Greenland (Surlyk, 1973, 1975).

The Nyker Group is topped by the uppermost Berriasian-Valanginian Jydegård Formation, which represents the final regressive phase of the TriassicLower Cretaceous evolution of the area. The depositional environment was a large lagoonal-lacustrine system dominated by clay deposition flanked to the south by sand of back-barrier and washover fan origin (Noe-Nygaard \& Surlyk, in prep.).

The lagoon seems mainly to have been brackish but freshwater conditions developed where parts of the lagoon were isolated or when the main inlets were blocked. The sequence is topped by sand and clay deposited in a system of small meandering channels. A fluviatile origin for these channels is likely but an origin as tidal channels cannot be excluded. Then follows the most important hiatus in the Mesozoic sequence and the Hauterivian, Barremian and Aptian Stages are all absent, while the Albian is represented only in pebbles of the basal conglomerate of the Cenomanian Arnager Greensand Formation (Kennedy et al., 1980). 


\section{Conclusion}

The Upper Triassic to Lower Cretaceous sequence of Bornholm is thus characterized by a series of hiati each followed by sedimentation during basin expansion. The main depositional environment throughout the period was in the transition zone between land and sea. Subsidence and sedimentation seem generally to have kept pace in the periods between the hiati. The combined evidence of these features suggests a strong tectonic control of the basin evolution. This is substantiated by the position of Bornholm in the Fenno-Scandian Border Zone, a major fault zone with a long and complex history. Comparison of the Bornholm sequence with the sea-level curves computed by Vail \& Todd (1981) for the North Sea region suggest eustatic control of the general facies evolution. This is particularly the case with the overall Early Jurassic transgression. A lateral basin expansion by gradual collapse and down-faulting of marginal areas (Rolle et al., 1979), as demonstrated for contemporaneous strata on East Greenland by Surlyk (1977b, 1978), combined by eustatic sea-level changes is thus suggested as the main features controlling deposition.

\section{Acknowledgements}

We thank H. Gry for fruitful discussions, O. Michelsen for critically reading the manuscript, and $\mathrm{B}$. Thomasen, C. Rasmussen, E. Glendal, J. Lautrup, I. Torres and Anna-Marie Svendsen for technical assistance. F. Rolle and F. Surlyk publishes with the permission of the Director of the Geological Survey of Greenland.

\section{Dansk sammendrag}

\section{Lithostratigrafi og sedimentologisk udvikling af Trias, Jura og Nedre Kridt på Bornholm, Danmark}

Den lithostratigrafiske inddeling af de triassiske, jurassiske og nedre kretasiske aflejringer på Bornholm er beskrevet, og der er foretaget en syntese af den tektoniske og sedimentologiske udvikling gennem sen Trias til tidlig Kridt.

Trias er på Bornholm repræsenteret af Risebæk Leddet (nyt), som er af sen Ladinien-Carnien Alder.
Risebæk Leddet henføres til den øvre lerede del af Kågeröd Formationen, der er velkendt fra Skåne.

Lagserien på Bornholm er karakteriseret af rødt og grønt flodsletteler og -silt, der indeholder en række forskellige typer af caliche knolde, som kan genfindes omlejret $\mathrm{i}$ isolerede konglomerater og $\mathrm{i}$ bunden af kanaler. Risebæk Leddet er hovedsagelig af kontinental oprindelse, aflejret $i$ et fladt kystnært landskab, som havet lejlighedsvis er trængt ind over.

Risebæk Leddet repræsenterer sandsynligvis den største udbredelse af det triassiske aflejringsbassin på Bornholm. Den øvre lerede del af Kågeröd Formationen kan tænkes at udgøre en udstrakt nordvestsydøst forløbende flodslette udviklet i randen af en serie alluvial kegler, der dannedes langs forkastninger op til Romele Åsen.

Klimaet var relativt varmt og aridt. I de mere centrale dele af aflejringsbassinet blev Oddesund Formationens rødbrune, brune og grå, anhydritholdige lersten og siltsten dannet under brakke og hypersaline forhold i periodevis oversvømmede sabkhaer, ephemerale søer og mere permanente saltsøer.

Bassinudvidelsen er tolket som resultatet af fremadskridende nedforkastning langs Den Fennoskandiske Randzone. Den mesozoiske tektoniske aktivitet var hovedsagelig ekstensionel, hvilket resulterede i blokforkastning og kipning af blokkene, men sideværts forkastningsbevægelser ledsaget af transpression med foldninger til følge forekom også. Den sen-triassiske blokforkastning ledsagedes af erosion, og der skete ingen aflejring af Rhaetien sedimenter på Bornholm, men de er eventuelt bevaret i dybe gravsænkninger lige vest og syd for øen.

Den jurassiske Bornholm Gruppe (ny) er opdelt i Rønne (nederst), Hasle og Bagå (øverst) Formationerne.

Rønne Formationen (ny) fra nedre Jura er opdelt i tre led. Munkerup Leddet (nyt) af Hettangien Alder blev aflejret først i den tidligt jurassiske sedimentationsfase, som skyldes fortsat tektonisk bassinudvidelse overpræget af eustatisk havstigning. Munkerup Leddet består af ler i forskellige generelt kraftige farver med et stort indhold af kul-detritus og plantefossiler. Desuden forekommer sandsten, lerjernsten og lerklastkonglomerater. Munkerup Leddet er aflejret under lakustrine forhold på enten triassiske sedimenter eller kambrisk kvartsit.

Under det videre sedimentationsforløb udvikledes en nedre delta-slette hurtigt, repræsenteret ved de nedre lag af det overliggende Sose Bugt Led (nyt) fra Hettangien til nederste Sinemurien. Lagserien er karakteriseret af krydslejret sand med kul-detritus, som delvis forekommer i kanaler, laminerede lerlag, kullag og rodhorisonter. Fortsat transgression er de- 
monstreret ved tilstedeværelsen af bølgeomlejrede sandlag, Skolithos og andre marine sporfossiler samt øverst af heterolithiske tidevandsfladeaflejringer.

Over Sose Bugt Leddet følger Galgeløkke Leddet (nyt) fra Sinemurien, der består af heterolither, krydslejret sand og kullag med få foraminiferer og muslinger samt stedvis Skolithos og Planolites. Dette led er tolket som en generelt regressiv serie af sandede og mudrede tidevandsflader med et større tidevandskanalkompleks, afsluttet af en kulførende marsksekvens.

Over Rønne Formationen følger Hasle Formationen (ny) af Nedre Pliensbachien Alder, bestående hovedsagelig af finkornet limonitisk krydslejret sandsten med underordnede ler- og siltlag samt lejlighedsvis med tynde grus- eller lerjernstenslag. Formationen indeholder talrige muslinger, snegle og brachiopoder samt belemniter, fiske- og plesiosaurrester og ammoniter. Hasle Formationen er aflejret under normale marine kystnære forhold og danner afslutningen på den kontinentale til marginalt marine aflejringssekvens i Nedre Jura på Bornholm.

Det generelle mønster af havniveauændringer kan parallelliseres med udviklingen i det Danske Subbassin og Skåne. Hettangien og Sinemurien transgressionerne er i bassinet markeret ved aflejring af åbent-marine lersten fra Fjerritslev Formationen, som mod bassinranden afløses af den øverste del af den sandede Gassum Formation og i Skåne af de sandede marginalt marine og deltaiske Helsingborg og Döshult Led og mere finkornede Pankarp Led. Åbent marine forhold blev etableret igennem hele bassinet og i Skåne i Pliensbachien med fortsat aflejring af ler fra Fjerritslev Formationen og mere siltede og sandede aflejringer fra Katslösa Leddet i Skåne, som svarer til den sandede Hasle Formation på Bornholm. Udviklingen af de fleste facies på Bornholm synes derfor at afspejle den tidlig jurassiske eustatiske havniveaustigning, mens udviklingen af de lokale aflejringsmiljøer og sekvensens "oversteppende" karakter synes at afspejle vekselvirkning mellem eustasi og blokforkastning i den Fennoskandiske Randzone.

Den næste tektoniske fase, som kontrollerede bassinudvikling og facies mønster, fandt sted ved begyndelsen af Mellem Jura. På Bornholm er der en hiatus svarende til etagerne Toarcien og Aalenien. Sedimentationen fortsatte først i Bajocien-Bathonien, hvor Bagå Formationen (ny) blev aflejret, men det er uvist om Toarcien-Aalenien mangler primært eller om fraværet skyldes erosion i forbindelse med starten på den mellem jurassiske tektoniske fase. Bagå Formationen består af krydslamineret sand, heterolither, ler og kul, som karakteristisk er aflejret i finende-opad cykler. Nederst $\mathrm{i}$ formationen findes ret tykke konglomerater, og øverst kan der på typelokaliteten findes meget dårligt sorterede resedimenterede konglomerater, som indeholder blokke af kaoliniseret granit. Bagå Formationen er dannet $\mathbf{i}$ et nedre deltaslettemiljø, hvor de finende-opad sand-ler cykler blev aflejret i et system af mæandrerende kanaler, leveer og sumpe. Marginalt marine forhold med leraflejring udvikledes i bugtområderne mellem kanalerne. Bagå Formationen er af regressiv natur og følger det generelle billede af den tektonisk kontrollerede Mellem Jura regression, som kendes fra Eriksdal Formationen i Skåne, Haldager Formationen i det Danske Subbassin, Brent Formationen i den nordlige Nordsø og Pelion Leddet i Østgrønland. At den tektoniske aktivitet fortsatte gennem Mellem Jura ses tydeligt af forekomsten af debris strøm konglomerater med store kaoliniserede granitblokke, der er kommet fra den nærliggende granithorsts stejle forkastningsskråning lige øst for aflejringsbassinet.

Bornholm Gruppen må forventes at være tilstede $\mathrm{i}$ havområdet omkring Bornholm i de dybe gravsænkningsområder vest og syd for øen. I øjeblikket vides der dog ikke noget detaljeret om de stratigrafiske forhold i disse områder.

En tredje større mellem mesozoisk hiatus følger over de mellem jurassiske aflejringer, eftersom hele Øvre Jura antagelig ikke findes på Bornholm. Dette skyldes formodentlig erosion i det allerseneste Jura under de første episoder af den næste fase af blokforkastning og bassinudvidelse. Nyker Gruppen (ny) fra Tithonien(?)-Berriasien-Valanginien hviler derfor med tydelig diskordans på ældre sedimenter og transgrederer store områder med stærkt kaoliniserede grundfjeldsbjergarter. Isolerede områder med sedimenter fra gruppen antyder at hele Bornholm nu for første gang i Mesozoikum var blevet et aflejringsmiljø. Dette svarer til Bream og Vedsted Formationernes generelle transgressive natur i det Danske Subbassin.

Nyker Gruppen er opdelt i Rabekke (nederst), Robbedale og Jydegård (øverst) Formationerne.

Rabekke Formationen begynder nederst med Homandshald Leddet (nyt) af Tithonien(?)-Nedre Berriasien Alder, som består af krydslejret og strukturløs jernholding sandsten, krydslejret dårligt sorteret sand med kaolin og sandet ler med plantemateriale og rodhorisonter. Homandshald Leddet er dannet som grovkornede daludfyldninger og ved aflejring i fluviatile kanaler. Det overliggende Skyttegård Led (nyt) fra Nedre- $\varnothing_{v r e}$ ? Berriasien er domineret af mangefarvet ler med silt og sandlag. Leret har et højt indhold af planter og finkornet plantedetritus med tynde lag af horisontalt aflejret lignit. Rodhorisonter forekommer og megasporer samt ostrakoder 
er fundet på få lokaliteter. Dette led er aflejret under lakustrine og marginalt marine forhold i kystnære supratidale sumpe. Skyttegård leddet er dannet samtidig med aflejringen af den øvre del af Vitabäck Ler Leddet i Skåne.

Hele Nyker Gruppen viser et groft regressivttrangsgressivt-regressivt mønster, hvor Robbedale Formationen fra $\emptyset v r e ?$ Berriasien repræsenterer det mest marine led i denne udvikling. Robbedale Formationen består for det meste nederst af Østerborg Leddet (nyt), der hovedsagelig udgøres af finkornet kvartssand undertiden med tynde lag af groft sand og grus eller ler.

Gallerier af Ophiomorpha og Skolithos er karakteristiske, men andre sporfossiler forekommer også, og sandet er ofte totalt bioturberet. Plantemateriale og rodhorisonter kan forekomme. Østerborg Leddet er dannet på strande, sandede tidevandsflader og i små laguner. Ovenover følger Langbjerg Leddet (nyt), som består af mellem- til grovkornet kvartssand undertiden med et mindre grusindhold og med mange lerdraperinger. Ophiomorpha er udbredt, mens Skolithos og andre sporfossiler forekommer mere sporadisk. Langbjerg Leddet tænkes aflejret på en højenergi barrierestrand og på marine sandbanker.

Nyker Gruppen afsluttes af Jydegård Formationen fra øverste Berriasien - Valanginien, som repræsenterer den sidste regressive fase. Formationen er opdelt i to led, som lateralt går over i hinanden. Tornhøj Leddet (nyt) er karakteriseret ved en hurtig vekslen mellem sedimenter af forskellig kornstørrelse. Fin- til grovkornet sand dominerer, mens silt, ler og lerjernsten optræder mindre hyppigt. Nederst i dette led er lagene pladeformede, mens små sand- og lerfyldte kanaler er til stede i den øvre del. Der kan findes lag med koncentrationer af monospecifiske selskaber af muslinger, snegle og conchostraker, mens vertebratrester og plantefossiler er mere spredte. Rødbjerg Leddet (nyt) er domineret af leraflejringer med tynde silt- og sandlag og med underordnede lerjernstenslag. Oolitisk chamosit er karakteristisk. I tynde lag kan findes foraminiferer, ostrakoder, snegle, fisketænder, sporer og planter. Hele Jydegård Formationen blev dannet $i$ et stort lagune-lakustrint system domineret af leraflejringer, som mod syd var afgrænset af sandede bagbarrierer og overskylsvifte aflejringer. Mæandrerende kanaler, dannet enten som små fluviatile kanaler $\mathrm{i}$ et nedre flodslettemiljø eller som tidevandskanaler, findes øverst i sekvensen. Lagunen har hovedsagelig været brak, men ferskvandsforhold blev udviklet, når dele af lagunen blev isoleret eller når større kanaler blev blokeret.

Efter aflejringen af Jydegård Formationen følger den vigtigste hiatus $\mathrm{i}$ den mesozoiske sekvens og
Hauterivien, Barremien og Aptien Etagerne mangler alle, mens Albien kun er repræsenteret som grus og sten i den Cenomane Arnager Grønsand Formations basalkonglomerat.

Øvre Trias til Nedre Kridt sekvensen på Bornholm er således karakteriseret ved en serie af hiati efterfulgt af bassinudvidelse og sedimentation. Det vigtigste aflejringsmiljø gennem perioden var i overgangszonen mellem land og hav, og indsynkning og sedimentation synes således generelt at have holdt trit med hinanden i perioderne mellem hiati.

Ved at kombinere vidnesbyrdene fra disse træk i den bornholmske sekvens, kan der påvises en stærk tektonisk kontrol over bassinudviklingen. Dette er understøttet af Bornholms beliggenhed i Den Fennoskandiske Randzone, som er en første ordens forkastningszone med en lang og kompleks historie.

Sammenligning med havniveaukurver for Nordsøregionen viser en generel korrelation især til den tidlig jurassiske transgression. Den lokale udvikling af aflejringsmiljøer og tilstedeværelsen af markante hiati kan derimod ikke forklares ud fra de eustatiske kurver.

En lateral bassinudvidelse med gradvis indsynkning og nedforkastning af de marginale områder med et overpræg af eustatiske havniveauændringer anses derfor som den vigtigste faktor, der har kontrolleret aflejringsforholdene.

\section{Literature}

Allen, J. R. L., 1965: Fining-upwards cycles in alluvial successions. - Geol. Journ., 4, pp. 229-246.

Allen, P., 1955: Age of the Wealden in North-Western Europe. Geol. Mag., 92, pp. 265-281.

Allen, P., 1967: Origin of the Hastings Facies in North-Western Europe. - Proc. Geol. Ass., 78, pp. 27-107.

Allen, P., 1975: Wealden of the Weald: a new model. - Proc. Geol. Ass., 86, pp. 389-437.

Andersen, S. A., 1944: Det danske landskabs historie. - I bind. Undergrunden. Populær-videnskabeligt forlag, København, 480 pp.

Andersen, O. B., Larsen, B. \& Platou, S. W., 1975: Gravity and geological structure of the Fenno-Scandian Border-Zone in the southern Baltic Sea. - Bull. geol. Soc. Denmark, 24, pp. 45-53.

Baartman, J. C., 1976: Structural outline of Denmark (Pre-Upper Permian). - In: Rasmussen, L. B., 1978: Geological aspects of the Danish North Sea sector. - Danm. geol. Unders. III rk., 44, 85 pp.

Baartman, J. C. \& Christensen, O. B., 1975: Contributions to the interpretation of the Fennoscandian Border Zone. - Danm. geol. Unders., II rk., 102, 47 pp.

Bartholin, C. T., 1892: Nogle i den bornholmske Juraformation forekommende Planteforsteninger. - Botan. Tidsskr., 18, pp. $12-28$. 
Bartholin, C. T., 1894: Nogle i den bornholmske Juraformation forekommende Planteforsteninger. - Botan. Tidsskr., 19, pp. 87-115.

Bartholin, C. T., 1910: Planteforsteningerne fra Holsterhus på Bornholm. - Danm. geol. Unders. II rk., 24, 36 pp.

Bertelsen, F., 1978: The Upper Triassic - Lower Jurassic Vinding and Gassum Formations of the Norwegian-Danish Basin. Danm. geol. Unders., Ser. B, 3, 26 pp.

Bertelsen, F., 1980: Lithostratigraphy and depositional history of the Danish Triassic. - Danm. geol. Unders., Ser. B, 4, 59 pp.

Bjelm, L., Hartlen, J., Röshoff, K., Bennet, J., Bruch, H., Persson, P.-G. \& Wadstein, P., 1977: Geotermisk energiutvinning i Skåne, slutrapport etapp 1. - Tekniska högskolan i Lund, Sweden.

Bowen, J. M., 1975: The Brent oil field. - In: Woodland, A. W. (ed.): Petroleum and the continental shelf of North-West Europe, Institute of Petroleum, London, pp. 353-361.

Casey, R., 1973: The ammonite succession at the Jurassic-Cretaceous boundary in Eastern England. - In: Casey, R. \& Rawson, P. F. (eds.): The Boreal Lower Cretaceous. - Geol. Journ. Sp. Issue, 5, pp. 193-266.

Christensen, O. B., 1963: Ostracods from the Purbeck-Wealden beds in Bornholm. - Danm. geol. Unders., II rk., 86, $58 \mathrm{pp}$.

Christensen, O. B., 1964: Jura-Kridt grænsen i det skånsk-pommerske område belyst ved ostrakoder. - Medd. Dansk Geol. Foren., 15, pp. 431-432.

Christensen, O. B., 1966: Om purbeckien aflejringerne i det nedsænkede område ved Salene Bugt, Bornholm. - Medd. Dansk Geol. Foren., 16, pp. 465-466.

Christensen, O. B., 1968: Some deposits and microfaunas from the Upper Jurassic in Scania. - Sver. geol. Unders. Ser. C., 632, 46 pp.

Christensen, O. B., 1972: Det danske sænkningsområdes udvikling i det mellemste Mesozoikum. - Dansk Geol. Foren., Årsskrift for 1971, pp. 55-62.

Christensen, O. B., 1974: Marine communications through the Danish Embayment during uppermost Jurassic and lowermost Cretaceous. - Geoscience and man, 6, pp. 99-115.

Dabrowska, Z., 1976: Palaegeography. Areas except the Carpathians and the Sudetes: Upper Jurassic. - In: Sokolowski, S. (ed.): Geology of Poland, vol. 1, Stratigraphy, Mesozoic, pp. 467-476.

Dadlez, R., 1974: Some geological problems of the southern Baltic basin. - Acta geol. Polon., 24, pp. 261-275.

Deegan, C. E. \& Scull, B. J. (compilers), 1977: A proposed standard lithostratigraphic nomenclature for the Central and Northern North Sea. - Rep. Inst. Geol. Sci., No. 77/25; Bull. Norw. Petrol. Direct., No. 1, 36 pp.

Dörhöfer, G., 1977: Palynologie und Stratigraphie der Bückeberg-Formation (Berriasium-Valanginium) in der Hilsmulde (NW-Deutschland). - Geol. Jahrb., Reihe A, 42, 122 pp.

Dörhöfer, G. \& Norris, G., 1977: Palynostratigraphische Beiträge zur Korrelierung jurassische-kretazischer Grenzschichten in Deutschland und England. - N. Jb. Geol. Paläont. Abh., 153, pp. 50-69.

Eynon, G., 1981: Basin Development and Sedimentation in the Middle Jurassic of Northern North Sea. - In: Illing, L. V. \& Hobson, G. D. (eds.): Petroleum Geology of the Continental shelf of North-West Europe, Institute of Petroleum, London, pp. 196-204.

Florin, R., 1958: On Jurassic taxads and conifers from NorthWestern Europe and eastern Greenland. - Acta Horti Bergiani, 17, no. 10, 402 pp.

Forchhammer, G., 1837: Om de Bornholmske Kulformationer. Vid. Sel. Naturvid. og mathem. Afh., VII Deel, 64 pp.
Graff-Petersen, P., 1961: Lermineralogien i de limniske jurasedimenter på Bornholm. - Dr. phil. thesis, University of Copenhagen, $149 \mathrm{pp}$.

Graff-Petersen, P. \& Bondam, J., 1963: Hasle klinkerfabrik Clay Pit and Rabekke Clay Pit. - Int. Clay Conf. Field Trip C. August 18th, 19 pp.

Gravesen, P., 1977a: Kystnære sedimentære aflejringer fra Øvre Jura - Nedre Kridt på Bornholm, Denmark. - Unpublished thesis, University of Copenhagen, $140 \mathrm{pp}$.

Gravesen, P., 1977b: A/S Carl Nielsens sandgrav, Robbedale (lok. 39) and Arnager Bugt (Øst for Madsegrav) (lok. 40). - Varv ekskursionsfører nr. 1, Geologi på Bornholm, pp. 73-82.

Gravesen, P., Bækgaard, A. \& Villumsen, A., 1980: 7. Områdebeskrivelse. - In: Bornholm, vandplanlægning, afsnit 2 . Hydrogeologisk kortlægning udført af Danmarks Geologiske Undersøgelse for Bornholms amtskommune, København okt. 1980, pp. $40-72$.

Gry, H., 1947: 14.-15. maj 1947. Exkursion til Bornholm. Medd. Dansk Geol. Foren., 11, pp. 228-229.

Gry, H., 1951: Kullagene ved Hasle på Bornholm og deres tektonik. - Medd. Dansk Geol. Foren., 12, pp. 172-173.

Gry, H., 1956: Wealdenaflejringerne på Bornholm. - Medd. Dansk Geol. Foren., 13, pp. 134-141.

Gry, H., 1960: Geology of Bornholm. - Guide to Excursions Nos. A 45 and C 40. Int. Geol. Congr. 21 Sess. Copenhagen, 16 pp.

Gry, H., 1968: Callianassagange og Skolithosrør i Robbedaleformationen. - Medd. Dansk Geol. Foren., 18, pp. 205-212.

Gry, H., 1969: Megaspores from the Jurassic of the Island of Bornholm, Denmark. - Medd. Dansk Geol. Foren., 19, pp. 69-89.

Gry, H., 1977a: Risegård-Risebæk (lok. 34). - Varv ekskursionsfører nr. 1, Geologi på Bornholm, pp. 56-58.

Gry, H., 1977b: Hasle klinkerfabriks lergrav (lok. 37) and Rabekkeværket (lok. 38). - Varv ekskursionsfører nr. 1, Geologi på Bornholm, pp. 69-72.

Grönwall, K. A., 1899: Bemærkninger om Bornholms sedimentære Dannelser og deres tektoniske Forhold. - Danm. geol. Unders., II rk., 10, pp. 1-48.

Grönwall, K. A. \& Milthers, V., 1916: Kortbladet Bornholm. Danm. geol. Unders., I rk., 13, 281 pp.

Harris, T. M., 1937: The Fossil Flora of Scoresby Sound, East Greenland. Part 5: Stratigraphic Relations of the Plant Beds. Medd. Grønland, 112, No. 2, 114 pp.

Hjort, A., 1899: Om Vellengsbyleret og dets Flora. - Danm. geol. Unders., II rk., 10, pp. 61-86.

Hughes, N. F., 1958: Palaeontological Evidence for the Age of the English Wealden. - Geol. Mag., 95, pp. 41-49.

Hughes, N. F., 1975: Plant succession in the English Wealden Strata. - Proc. Geol. Ass., 86, pp. 439-455.

Höhne, R., 1933: Beiträge zur Stratigraphie, Tektonik und Paläogeographie des südbaltischen Rhät-Lias, insbesondere auf Bornholm. - Abh. Geol.-Pal. Inst. Greifswald, 12, 105 pp.

Jespersen, M., 1865: Liden geognostisk Veiviser paa Bornholm. Rønne, $1865,67 \mathrm{pp}$.

Jespersen, M., 1866: En Skitse af Sorthats Kulværk paa Bornholm. - Indbydelsesskrift til de offentlige Examina i Rönne höiere Realskole, pp. 5-38.

Jespersen, M., 1869: Bidrag til Bornholms Geotektonik. II. De geotektoniske Forhold i Knudskerplateauets Omegn. - Naturhist. Tidsskr., 3. rk., 6, pp. 1-48.

Johnstrup, F., 1889: Abriss der Geologie von Bornholm, als Führer zu der Exkursion der Deutschen geologischen Gesellschaft nach der Insel Bornholm in Anschluss an die allgemeine Versammlung in Greifswald 1889. - Der Deutschen Geologischen Gesellschaft, Versammlung 1889, Greifswald, pp. 1-66. 
Jux, U. \& Strauch, F., 1968: Ophiomorpha Lundgren 1891 aus dem Mesozoikum von Bornholm. - Medd. Dansk Geol. Foren., 18, pp. 213-219.

Kemper, E., 1973: Das Berrias (tiefe Unterkriede) in NWDeutschland. - Geol. Jahrb., Reihe A, 9, pp. 47-67.

Kennedy, W. J., Hancock, J. M. \& Christensen, W. K., 1980: Albian and Cenomanian ammonites from the island of Bornholm (Denmark). - Bull. genl. Soc. Denmark, 29, pp. 203-244.

Koch, J.-O., 1979: Sen-Palæozoisk-Mesozoisk bassinudvikling i det danske område og Mellem og Øvre Jurassisk sedimentation ved Eriksdal i Skåne. - Unpublished thesis, University of Copenhagen, 97 pp.

Kumpas, M. G., 1980: Seismic stratigraphy and tectonics in Hanö Bay, southern Baltic. - Stockholm Contr. Geol., 34, pp. 35-168.

Kögler, F.-C. \& Larsen, B., 1979: The West Bornholm basin in the Baltic Sea, geological structure and Quaternary sediments. Boreas, 8, pp. 1-22.

Köster, E., 1956: Aufbau und Sedimentationsrhythmen der Kågerödformation in der Bohrung Klappe in nordwestlichen Schonen. - Geol. Fören. Förhandl, 78, pp. 463-502.

Lundgren, B., 1879: Bidrag till kännedomen om Juraformationen på Bornholm. - Festskr. til Univ. i Köpenhamm, Lunds Universitet, $29 \mathrm{pp}$.

Malling, C., 1911: Hasle-Sandstenens alder. - Medd. Dansk Geol. Foren., 3, pp. 629-631.

Malling, C., 1914: De Jespersenske Buelag i Lias på Bornholm. Medd. Dansk Geol. Foren., 4, pp. 265-270.

Malling, C., 1920: Foredrag om den marine Lias og Wealden-Aflejringer paa Bornholm. - Medd. Dansk Geol. Foren., 5, pp. $55-57$.

Malling, C. \& Grönwall, K. A., 1909: En Fauna i Bornholms Lias. - Medd. Dansk Geol. Foren., 15, pp. 271-316.

Michelsen, O., 1978: Stratigraphy and distribution of Jurassic deposits of the Norwegian-Danish Basin. - Danm. geol. Unders., Ser. B, 2, 28 pp.

Milthers, V., 1930: Bornholms Geologi. - Danm. geol. Unders., V rk., 1, $140 \mathrm{pp}$.

Möller, H., 1902: Bidrag till Bornholms Fossila Flora. Pteridofyter. - Lunds Univ. Årsskr., 38, Afd. 2, nr. 5, 63 pp.

Möller, H., 1903: Bidrag till Bornholms Fossila Flora (Rhät och Lias). Gymnospermer. - Kgl. Svenska Vitensk. Akad. Hand., 36 , no. $6,56 \mathrm{pp}$.

Nilsson, T., 1959: Über das Vorkommen eines mesozoischen Sapropelgesteins in Schonen. - Lunds Univ. Årsskrift 1958 N. F. Avd. 2, 54, pp. 1-111.

Norling, E., 1972: Jurassic stratigraphy and foraminifers of western Scania, southern Sweden. - Sver. geol. Unders. Ser Ca, 47, $120 \mathrm{pp}$.

Norling, E., 1981: Upper Jurassic and Lower Cretaceous geology of Sweden. - Geol. Fören. Förhandl., 103, pp. 253-269.

Norling, E. \& Skoglund, R., 1977: Der Südwestrand der Osteuropäischen Tafel im Bereich Schwedens. - Zeitschrift angew. Geol., 23, pp. 449-458.

Norling, E., Wikman, H., Sivhed, U. \& Karis, L., 1981: Berggrundskartan 3B Höganäs NO/ 3C Helsingborg NV. - Sver. geol. Unders. Ser Af, 129.

Ravn, J. P. J., 1925: Det cenomane Basalkonglomerat paa Bornholm. - Danm. geol. Unders., II rk., 42, 64 pp.

Rolle, F., 1977: Sosevig (lok. 35) and Galløkken (lok. 36). - Varv ekskursionsfører nr. 1, Geologi på Bornholm, pp. 58-68.
Rolle, F., 1978: Sedimentationsmiljøer i Nedre Jura på Bornholm. - Unpublished thesis, University of Copenhagen, $85 \mathrm{pp}$.

Rolle, F., Koch, J.-O., Frandsen, N. \& Surlyk, F., 1979: Jurassic environments in the Fenno-Scandian Border Zone. - Symposium "Sedimentation jurassique W. européen." Association des Sédimentologistes Francais, Publication spéciale No. I, pp. $15-31$.

Rørdam, K., 1890: Undersøgelse af mesozniske Ierarter og Kanlin paa Bornholm i geologisk og teknisk Henseende. - Danm. geol. Unders., II rk., 1, 109 pp.

Sellwood, B. W., 1972: Tidal-flat sedimentation in the Lower Jurassic of Bornholm, Denmark. - Palaeogeogr., Palaeoclimatol., Palaeoecol., 11, pp. 93-106.

Sellwood, B. W., 1975: Lower Jurassic Tidal-Flat Deposits, Bornholm, Denmark. - In: Ginsburg, R. N. (ed.): Tidal deposits. A Casebook of Recent Examples and Fossil Counterparts. Springer-Verlag, pp. 93-101.

Sivhed, U., 1980: Lower Jurassic ostracodes and stratigraphy of western Skåne, southern Sweden. - Sver. geol. Unders. Ser Ca, $50,84 \mathrm{pp}$.

Sorgenfrei, T. 1966: Strukturgeologischer Bau von Dänemark. Geologie, 15, pp. 641-660.

Surlyk, F., 1973: The Jurassic-Cretaceous boundary in Jameson Land, East Greenland. - In: Casey, R. \& Rawson, P. F. (eds.): The Boreal Lower Cretaceous. Geol. J. Spec. Iss., 5, pp. 81-100.

Surlyk, F., 1975: Fault-controlled marine fan-delta sedimentation at the Jurassic-Cretaceous boundary, East Greenland. -9 th International Congress of Sedimentology, Theme 4, 2, pp. 305312.

Surlyk, F., 1977a: Stratigraphy, tectonics and palaeogeography of the Jurassic sediments of the areas north of Kong Oscars Fjord, East Greenland. - Bull. Grønlands geol. Unders., 123, 56 pp.

Surlyk, F., 1977b: Mesozoic faulting in East Greenland. - In: Frost, R. T. C. \& Dikkers, A. J. (eds.): Fault tectonics in N. W. Europe. - Geologie mijnb., 56(4), pp. 311-327.

Surlyk, F., 1978: Jurassic basin evolution in East Greenland. Nature, 274(5667), pp. 130-133.

Surlyk, F., 1980: Denmark. - In: Geology of the European countries, Denmark, Finland, Iceland, Norway, Sweden, 1-50. Dunod. Published in cooperation with the Comité National Francais de Géologie (C.N.F.G.) on the occasion of the 26th International Geological Congress.

Surlyk, F., Callomon, J. H., Bromley, R. G. \& Birkelund, T. 1973: Stratigraphy of the Jurassic - Lower Cretaceous sediments of Jameson Land and Scoresby Land, East Greenland. - Meddr Grønland, 193, 5, $76 \mathrm{pp}$.

Surlyk, F. \& Clemmensen, L., in press: Rift propagation and eustacy as controlling factors during Jurassic inshore and shelf sedimentation in Northern East Greenland. - Sediment. Geol.

Troedsson, G., 1934: Undersökning av möjligheten att erhålla grundvatten från Hälsingborgtraktens berggrund. - Hälsingsborgs Stadsfullm. Handl., 25, $30 \mathrm{pp}$.

Troedsson, G., 1942: Bidrag till Kännedommen om Kågerödsformationen i Skåne. - Geol. Fören. Förhandl., 64, pp. 289328.

Vail, P. R. \& Todd, R. G., 1981: Northern North Sea Jurassic Unconformities, Chronostratigraphy and Sea-level Changes from Seismic Stratigraphy. - In: Illing, L. V. \& Hobson, G. D. (eds.): Petroleum Geology of the Continental shelf of NorthWest Europe, Institute of Petroleum, London, pp. 216-235. 